\title{
Kinetics of $\mathrm{Rh}(\mathrm{II})$-Catalyzed $\alpha$-Diazo- $\beta$-ketoester Decomposition and Application to the $[3+6+3+6]$ Synthesis of Macrocycles on a Large Scale and at Low Catalyst Loadings
}

\author{
Daniele Poggiali, ${ }^{a}$ Alexandre Homberg, ${ }^{a}$ Timothée Lathion, ${ }^{b}$ Claude Piguet, ${ }^{b}$ Jérôme \\ Lacour $^{\mathrm{a}, *}$ \\ a Department of Organic Chemistry, Quai E. Ansermet 30, University of Geneva, Switzerland. \\ ${ }^{b}$ Department of Inorganic and Analytic Chemistry, Quai E. Ansermet 30, University of \\ Geneva, Switzerland. \\ * jerome.lacour@unige.ch
}

\section{Electronic Supporting Information}

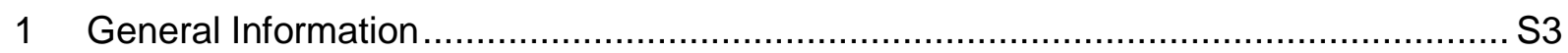

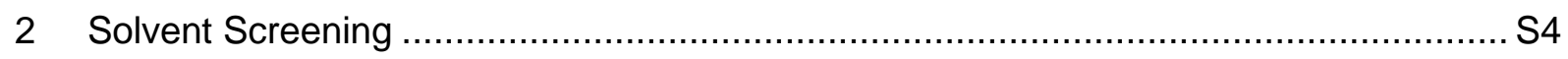

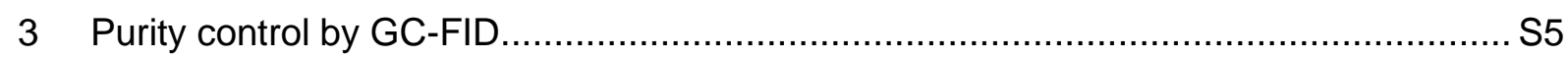

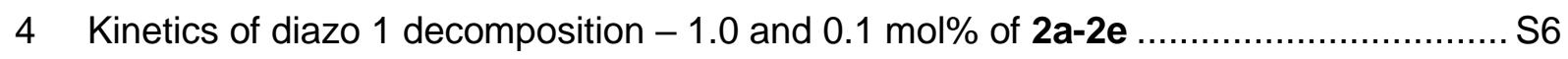

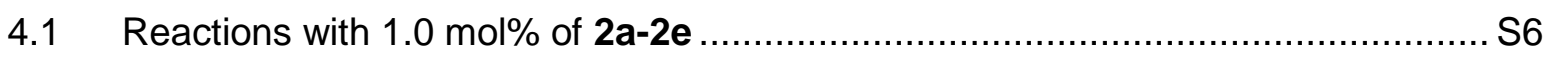

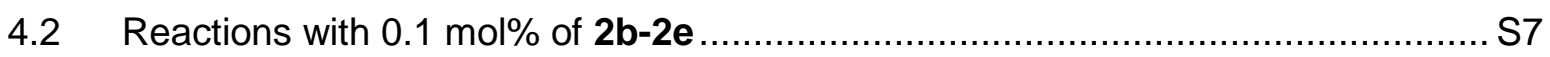

5 Coordination of complexes $\mathrm{Rh}_{2} \mathrm{~L}_{4}$ by 1,4 -dioxane. Equilibrium constants and speciation. S9

5.1 Equilibrium constants - Spectrophotometric titration ..................................... S9

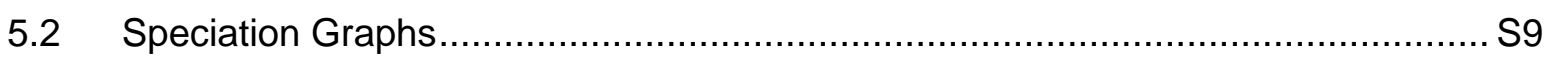

6 Kinetics of diazo decomposition varying the amount of 1,4 -dioxane ........................... 18

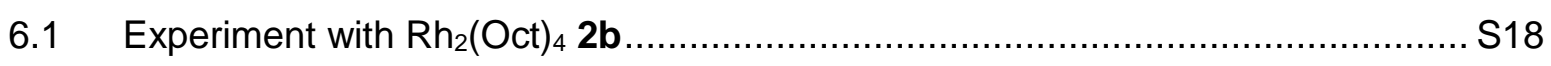

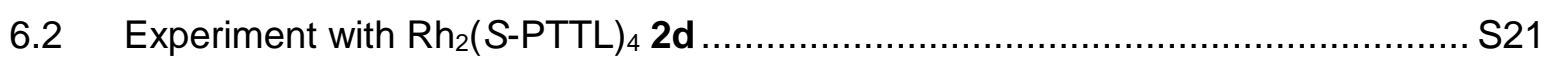

6.3 Speciation of $\mathrm{Rh}_{2}(S-\mathrm{PTTL})_{4}$ and comparison of $k_{1}$ in relation with the equivalents of

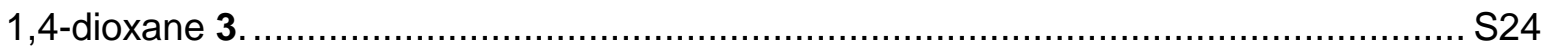

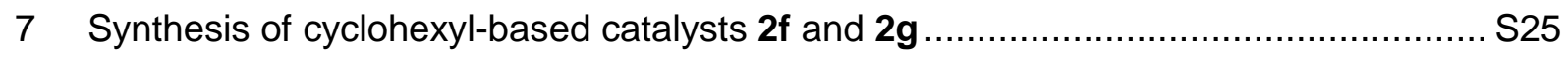

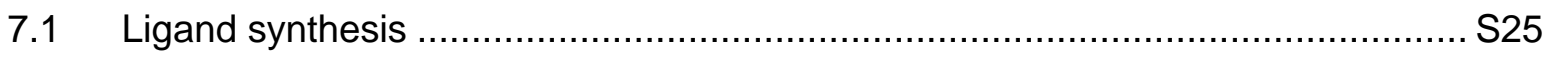




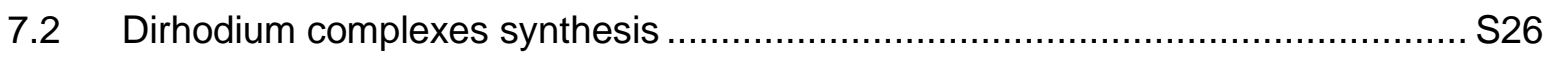

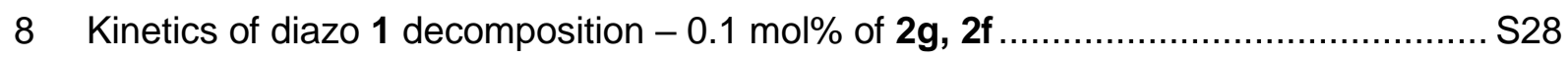

9 200-mg, 1-g and 20-g scale reactions at $0.001 \mathrm{~mol} \%$ of catalysts ............................. S30

$9.1200 \mathrm{mg}$-scale: $10 \mathrm{ml}$ microwave capped vials............................................. S30

9.21 -g-scale: $25 \mathrm{ml}$ schlenk tube equipped with a reflux condenser ......................... 330

9.320 -g-scale: $500 \mathrm{ml}$ three neck flask equipped with a reflux condenser ................ 330

$9.420-g$ scale reactions: ${ }^{1} \mathrm{H}$ NMR analysis of the initial precipitates .......................... S32

10 Reaction scope with catalyst $\mathbf{2 g}$ at 0.01 mol\% - Diazo reagent screening .................. S33

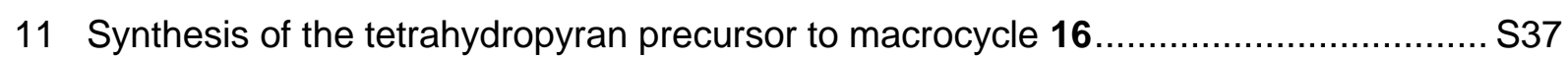

12 Reaction scope with catalyst $\mathbf{2} \mathbf{g}$ at 0.01 mol\% - Substituted THP substrates.............. S38

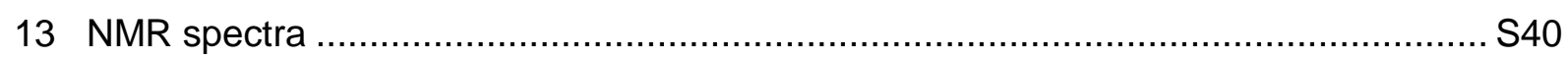

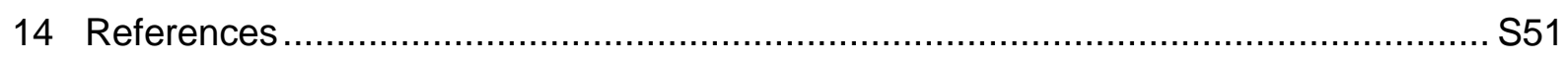




\section{General Information}

${ }^{1} \mathrm{H}$ and ${ }^{13} \mathrm{C}$ NMR experiments were recorded at $298 \mathrm{~K}$ on a Bruker AVANCE III HD-NanoBay $400 \mathrm{MHz}$ spectrometer, equipped with a $5 \mathrm{~mm}$ CryoProbe Prodigy or, on a Bruker III $500 \mathrm{MHz}$ spectrometer, equipped with a $5 \mathrm{~mm}$ Cryogenic $\mathrm{DCH}\left({ }^{1} \mathrm{H} /{ }^{13} \mathrm{C}\right)$ probe. ${ }^{1} \mathrm{H}-\mathrm{NMR}$ : chemical shifts are given in ppm relative to $\mathrm{Me}_{4} \mathrm{Si}$ with solvent resonances used as internal standards (7.26 ppm for $\mathrm{CDCl}_{3}, 2.50 \mathrm{ppm}$ for DMSO- $d_{6}, 5.32 \mathrm{ppm}$ for $\mathrm{CD}_{2} \mathrm{Cl}_{2}$ ). Data were reported as follows: chemical shift $(\delta)$ in ppm on the $\delta$ scale, multiplicity $(s=$ singulet, $d=$ doublet, $t=$ triplet, hept $=$ heptuplet, $\mathrm{dd}=$ doublet of doublet, $\mathrm{dt}=$ doublet of triplet, and $\mathrm{m}=$ multiplet), coupling constant $(\mathrm{Hz})$ and integration. ${ }^{13} \mathrm{C}-\mathrm{NMR}$ : chemicals shifts were given in ppm relative to $\mathrm{Me}_{4} \mathrm{Si}$ with solvent resonances used as internal standards $\left(77.16 \mathrm{ppm}\right.$ for $\mathrm{CDCl}_{3}, 39.52$ for DMSO- $d_{6}$, $53.84 \mathrm{ppm}$ for $\mathrm{CD}_{2} \mathrm{Cl}_{2}$ ). IR spectra were recorded with a Perkin-Elmer $100 \mathrm{FT}$-IR spectrometer using a diamond ATR Golden Gate sampling. Melting points $(\mathrm{mp})$ were measured in open capillary tubes with a Buchi B-550 melting points apparatus and are uncorrected. Electrospray mass spectra were obtained on a Finnigan SSQ 7000 spectrometer by the Department of Mass Spectroscopy at the University of Geneva. Analytical thin-layer chromatography (TLC) was performed with Silicagel $60 \mathrm{~F}_{254}$ aluminum sheets from Merck. Column chromatography was performed in air using Silica SiliaFlash P60, 40-63 $\mu \mathrm{m}$ (230-400 mesh) and Aluminium oxide (neutral, Brockmann I, 50-200 $\mu \mathrm{m}, 60 \AA$ ). IR in-situ reaction monitoring measurements were performed on a ReactIR ${ }^{\circledR}$ iC45 instrument (Mettler Toledo) equipped with a MCT detector and a SiComp (Silicon) probe connected via an AgX $9.5 \mathrm{~mm} \times 1.5 \mathrm{~m}$ fiber (Silver Halide) at $298 \mathrm{~K}$ (Thermostat controlled temperature). GC-FID analyses were performed on an Agilent 6850 instrument equipped with an Agilent 7683 injector. HP-1 (Agilent) $30.0 \mathrm{~m} \times 0.32 \mathrm{~mm} \times 0.25 \mu \mathrm{m}$ nominal column was used with $\mathrm{H}_{2}$ as gas vector $(1 \mathrm{~mL} / \mathrm{min})$. Sample prepared with $8 \mathrm{mg}$ of product dissolved in analytical grade THF stabilized by BHT. Elemental analyses were performed by K. L. Buchwalder from the Microchemical Laboratory of the University of Geneva

\section{Materials}

Commercial p.a. 1,4-dioxane was distilled from a sodium/benzophenone mixture and stored under $4 \AA$ molecular sieves. $\mathrm{CH}_{2} \mathrm{Cl}_{2}, \mathrm{CHCl}_{3}$ and $\mathrm{CDCl}_{3}$ were washed with $\mathrm{K}_{2} \mathrm{CO}_{3}$, filtered, refluxed $20 \mathrm{~h}$ with $\mathrm{CaCl}_{2}$ and distilled. $\mathrm{Rh}_{2}(\mathrm{OAc})_{4}$ used for ligand exchange was purchased from Pressure Chemical and used without further purification. $\mathrm{Rh}_{2}(\mathrm{OAc})_{4}$, used for catalysis, was purchased by Sigma-Aldrich. $\mathrm{Rh}_{2}(R \text {-DOSP })_{4}$ was purchased by $S t r e m$. $R h_{2}(\mathrm{Oct})_{4}, \mathrm{Rh}_{2}(S$ PTTL) $)_{4}$ and $R h_{2}(S-T C P T T L)_{4}$, were synthetized according to reference ${ }^{1}$ or modified procedures. 


\section{Solvent Screening}

$\mathrm{Rh}_{2}(\mathrm{Oct})_{4} \mathbf{2 b}$ (10.96 mg, $\left.14.07 \mu \mathrm{mol}, 1.0 \mathrm{~mol} \%\right)$, 1,4-dioxane 3 (0.720 mL, $8.4 \mathrm{mmol}, 6.0$ equiv) and one of the solvent detailed in Table $\mathrm{S} 1(1.61 \mathrm{~mL})$ were introduced into a $10 \mathrm{~mL}$ microwave vial $\left(\mathrm{V}_{\text {tot }}=2.33 \mathrm{~mL}\right)$. To this solution diazo 1 (200 mg, $1.41 \mathrm{mmol}, 1.0$ equiv) was added in one portion, the vial was capped and the mixture stirred at $1000 \mathrm{rpm}$ using a $6 \mathrm{~mm} \times 2 \mathrm{~mm}$ magnet stirrer for $20 \mathrm{~h}$ at $25^{\circ} \mathrm{C}$ (initial diazo 1 concentration $=0.6 \mathrm{M}$ ).

After total consumption of diazo 1 (TLC monitoring), the pressure in the vial was released and the crude mixture was transferred into a round bottom flask. The reaction vessel was rinsed with $\mathrm{CH}_{2} \mathrm{Cl}_{2}$ (x3) and the combined solutions concentrated in vacuo. The recovered solid was dissolved in $1.0 \mathrm{~mL}$ of $\mathrm{CH}_{2} \mathrm{Cl}_{2}$, precipitated in $20 \mathrm{~mL}$ of pentane, filtered on a $\mathrm{P} 3$ sintered glass filter and washed with ether:pentane (1:9). The white solid recovered was dissolved in $\mathrm{CH}_{2} \mathrm{Cl}_{2}$, concentrated and dried under vacuum to yield macrocycle 4 . The purity of product 4 was analyzed as detailed in section 3 .

Table S1 Solvent screening, yields and purities using $\mathrm{Rh}_{2}(\mathrm{Oct})_{4}$ and 6.0 equivalents of 1,4-dioxane 3 .

\begin{tabular}{cccc}
\hline Entry & Solvent & ${\text { Yield }[\%]^{\mathrm{a}}}$ & Purity $^{\mathrm{b}}$ \\
\hline 1 & $\mathrm{CH}_{2} \mathrm{Cl}_{2}$ & 67 & 95.5 \\
2 & $\mathrm{CHCl}_{3}$ & 68 & 96.4 \\
3 & Chlorobenzene & 64 & 93.2 \\
4 & Toluene & 61 & 93.6 \\
5 & EtOAc & 46 & 93.7 \\
6 & Hexane & 34 & 53.3 \\
\hline
\end{tabular}

a Yield corrected by GC-FID purity. ${ }^{\text {b }}$ Analyzed by GC-FID. 


\section{Purity control by GC-FID}

Product $\mathbf{4}$ was previously characterized. ${ }^{2}$

Figure S1 shows an example of GC-FID chromatogram of macrocycle 4 after isolation by precipitation, with a purity of $95.1 \%\left(t_{R}: 28.452 \mathrm{~min}\right.$.).

Sample preparation: ca. $8 \mathrm{mg}$ of 4 in $1.5 \mathrm{ml}$ of THF p.a., stabilized with BHT.

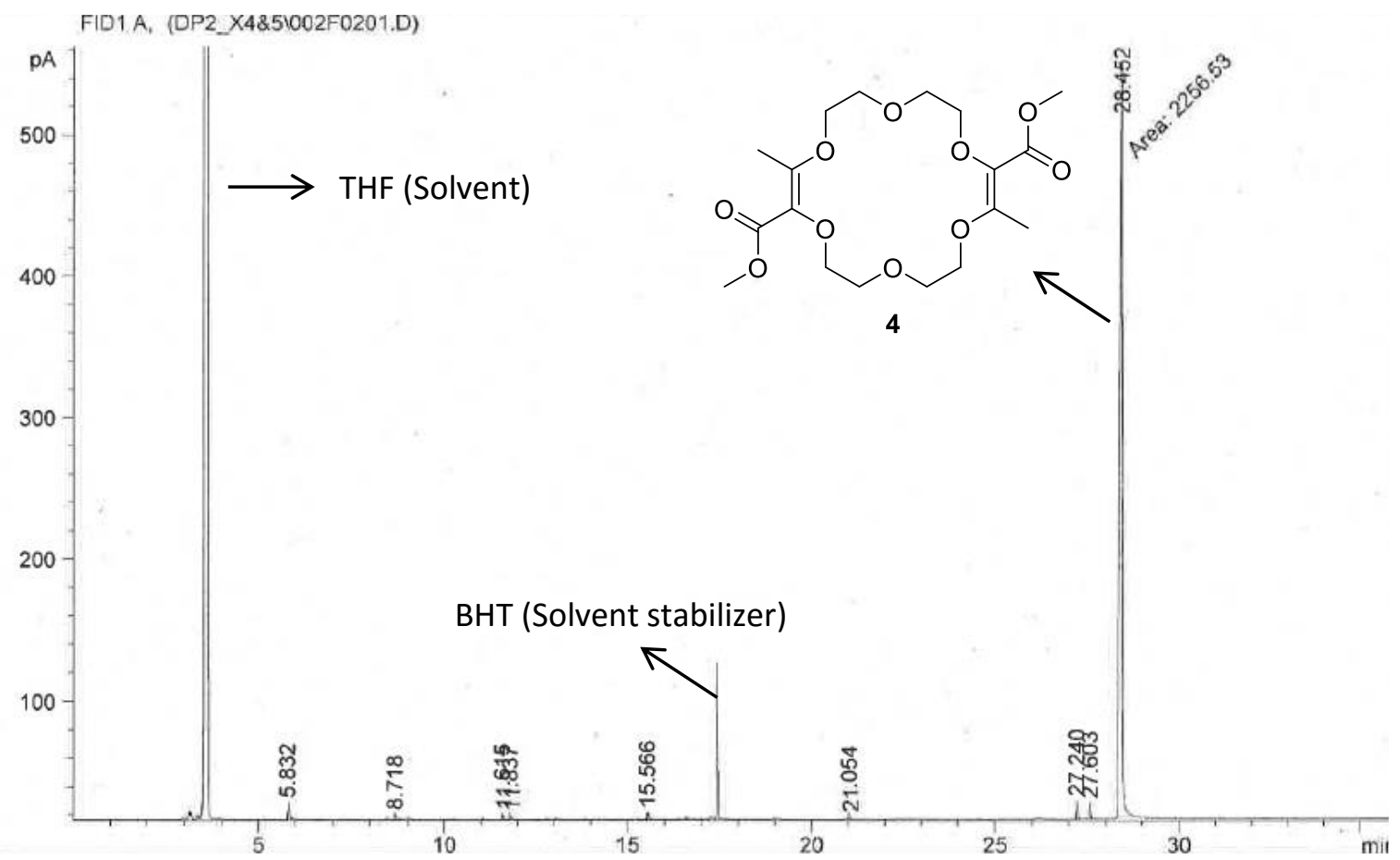

Figure S1 GC-FID chromatogram used to control the purity of isolated macrocycle 4 (after precipitation). Peak of THF (solvent) and BHT (solvent stabilizer) are not taken in account. 


\section{Kinetics of diazo 1 decomposition -1.0 and $0.1 \mathrm{~mol} \%$ of $2 \mathrm{a}-2 \mathrm{e}$}

$\mathrm{Rh}_{2} \mathrm{~L}_{4}$ (2a-2e) with a loading of 1.0 mol\% (0.01 equiv) or $0.1 \mathrm{~mol} \%$ (0.001 equiv), 1,4-dioxane $3\left(0.540 \mu \mathrm{L}, 6.33 \mathrm{mmol}, 6.0\right.$ equiv) and $1.21 \mathrm{~mL}$ of $\mathrm{CHCl}_{3}$ were mixed into a temperature controlled $\left(25^{\circ} \mathrm{C}\right)$ schlenk tube, under $\mathrm{N}_{2}$, and stirred using a $5 \mathrm{~mm} \times 2 \mathrm{~mm}$ magnet stirrer at $1000 \mathrm{rpm}$. The Reactl $\mathrm{R}^{\circledR}$ probe was introduced in the solution and a background spectrum recorded. Diazo 1 (150 mg, $1.06 \mathrm{mmol}, 1.0$ equiv) was added in one portion and one spectrum per minute was recorded.

Diazo 1 decomposition was monitored by its $2146 \mathrm{~cm}^{-1}$ infrared absorption band. The intensity of the peak at $\mathrm{t}=0[\mathrm{~h}]$ was normalized with the initial concentration of diazo $1=0.6 \mathrm{M}$. The points recorded for each experiment were linearized with In|diazo 1| vs. time [h] (first order linearization). The opposite of the slope corresponds to the kinetic constant $\boldsymbol{k}_{1}\left[\mathrm{~h}^{-1}\right]$ for the decomposition of diazo 1.

\subsection{Reactions with $1.0 \mathrm{~mol} \%$ of $2 a-2 e$}

Reaction profiles with 1.0 mol\% of catalysts $\mathbf{2 a}-\mathbf{2 e}$ are reported in the main manuscript (Figure 2).

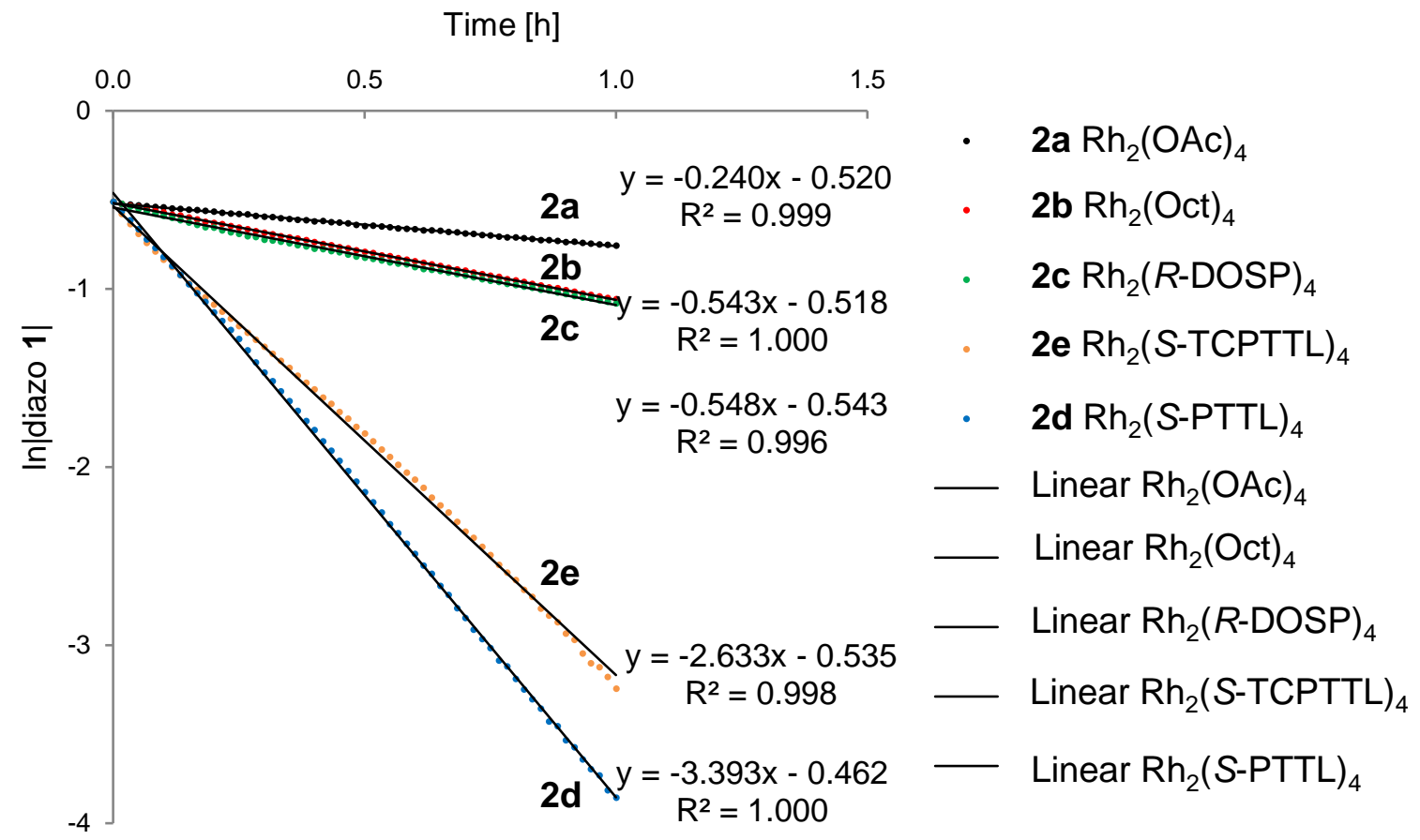

Figure S2 First order linearization of diazo 1 concentration and corresponding trend lines. Experiments using 1.0 mol\% of $\mathrm{Rh}_{2} \mathrm{~L}_{4}(\mathbf{2 a}-\mathbf{2 e})$. 
Table S2 Pseudo-first order kinetic constants $\boldsymbol{k}_{1}$ for the decomposition of diazo 1 using $1.0 \mathrm{~mol} \%$ of $\mathrm{Rh}_{2} \mathrm{~L}_{4}(\mathbf{2 a}-\mathbf{2 e})$. Yields and purities of isolated macrocycle 4.

\begin{tabular}{|c|c|c|c|c|c|}
\hline Entry & Complex & $k_{1}\left[h^{-1}\right]$ & $R^{2}$ & Yield [\%] $^{a}$ & Purity [\%] $]^{\mathrm{b}}$ \\
\hline 1 & 2a $\mathrm{Rh}_{2}(\mathrm{OAc})_{4}$ & 0.24 & 0.999 & 52 & 89.4 \\
\hline 2 & 2b Rh ${ }_{2}(\mathrm{Oct})_{4}$ & 0.54 & 1.000 & 65 & 96.9 \\
\hline 3 & 2c $\mathrm{Rh}_{2}(R \text {-DOSP })_{4}$ & 0.55 & 0.996 & 75 & 96.7 \\
\hline 4 & 2d Rh ${ }_{2}(S-\mathrm{PTTL})_{4}$ & 3.39 & 1.000 & 77 & 99.6 \\
\hline 5 & 2e $\mathrm{Rh}_{2}(S-\mathrm{TCPTTL})_{4}$ & 2.63 & 0.998 & 57 & 98.0 \\
\hline
\end{tabular}

a Yield corrected by GC-FID purity. ${ }^{b}$ Analyzed by GC-FID.

\subsection{Reactions with $0.1 \mathrm{~mol} \%$ of $2 \mathrm{~b}-2 \mathrm{e}$}

Reaction profiles with 0.1 mol\% of catalysts $\mathbf{2 b}-\mathbf{2 e}$ are reported below.

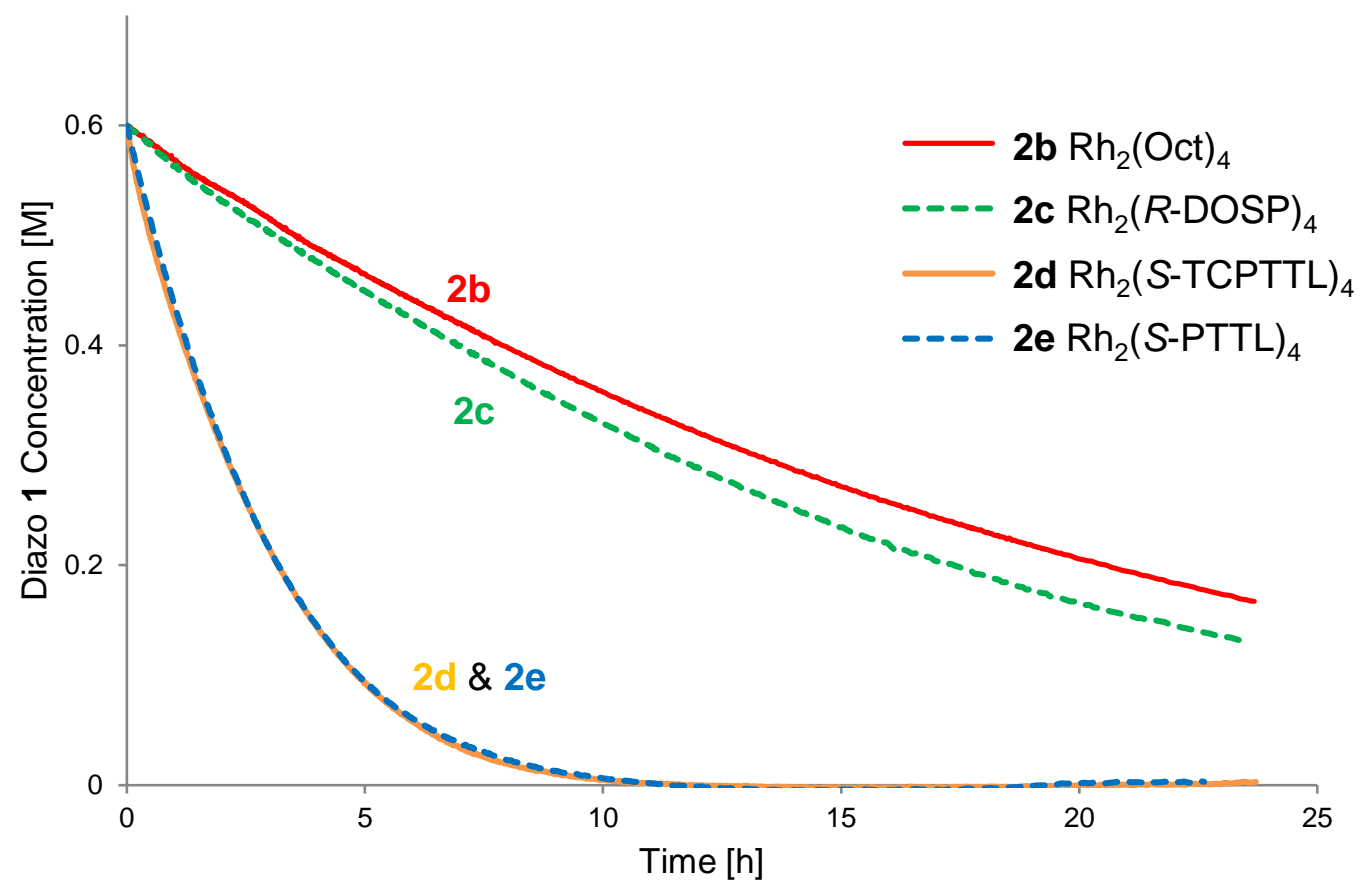

Figure S3 Diazo 1 concentration [M] evolution during reaction time [h] using $0.1 \mathrm{~mol} \%$ of different $\mathrm{Rh}_{2} \mathrm{~L}_{4}$ complexes (2b-2e). Trends from $2146 \mathrm{~cm}^{-1} \mathrm{IR}$ intensity, normalized at to $=0.6 \mathrm{M}$ for diazo 1 . 


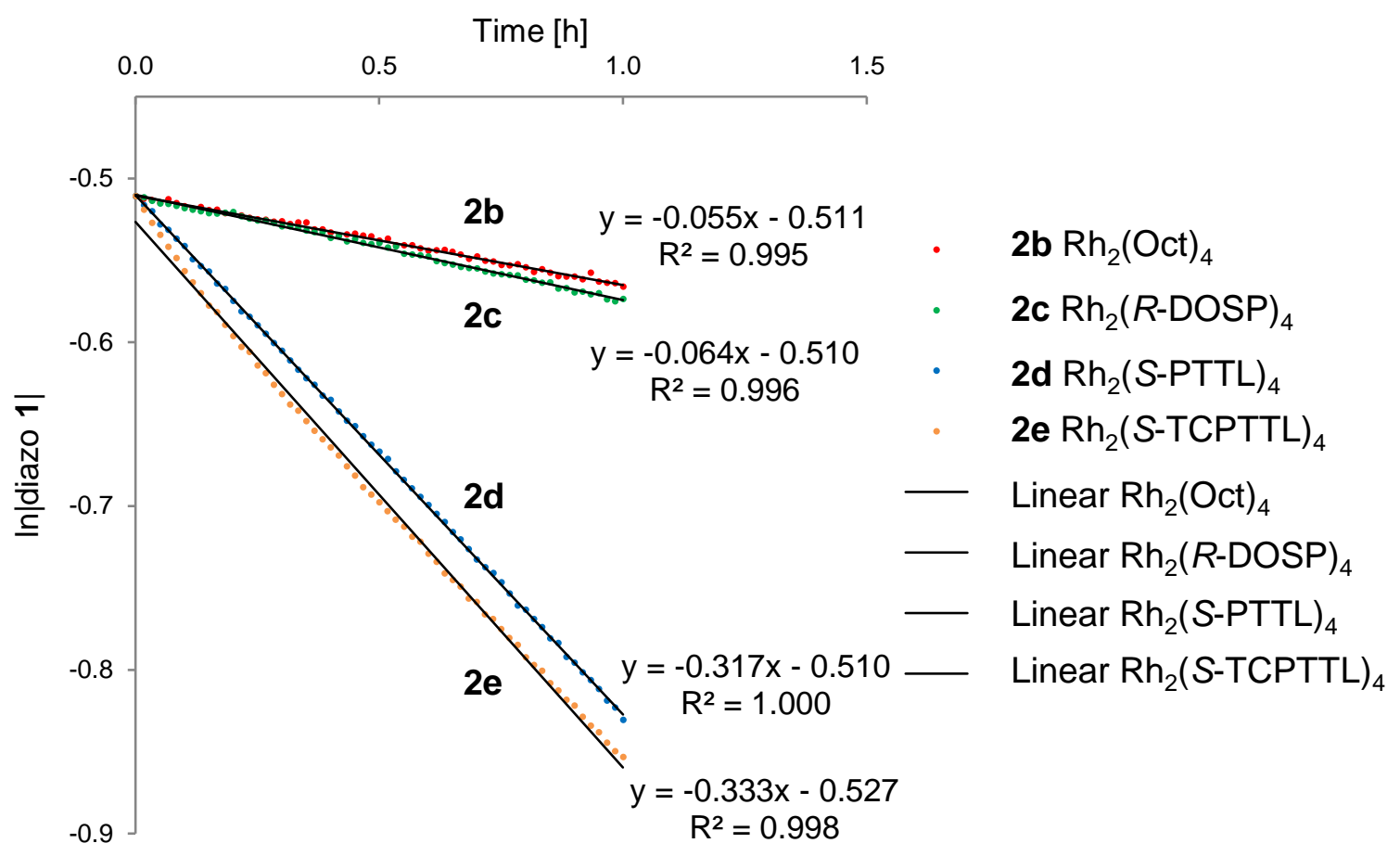

Figure S4 First order linearization of diazo concentration and corresponding trend lines. Experiments using $0.1 \mathrm{~mol} \%$ of $\mathrm{Rh}_{2} \mathrm{~L}_{4}(\mathbf{2 b}-\mathbf{2 e})$.

Table S3 Pseudo-first order kinetic constants $\boldsymbol{k}_{1}$ for the decomposition of diazo 1 using $0.1 \mathrm{~mol} \%$ of $\mathrm{Rh}_{2} \mathrm{~L}_{4}(\mathbf{2 b}-\mathbf{2 e})$. Yields and purities of isolated macrocycle 4.

\begin{tabular}{|c|c|c|c|c|c|}
\hline Entry & Complex & $k_{1}\left[h^{-1}\right]$ & $R^{2}$ & Yield [\%] & Purity [\%] ${ }^{b}$ \\
\hline 1 & 2b $\mathrm{Rh}_{2}(\mathrm{Oct})_{4}$ & 0.05 & 0.995 & $53^{c}$ & $81.2^{c}$ \\
\hline 2 & 2c $\mathrm{Rh}_{2}(R \text {-DOSP })_{4}$ & 0.06 & 0.996 & $57^{c}$ & $77.8^{c}$ \\
\hline 3 & 2d Rh $2(S-P T T L)_{4}$ & 0.32 & 1.000 & 76 & 98.8 \\
\hline 4 & 2e $\operatorname{Rh}_{2}(S-T C P T T L)_{4}$ & 0.33 & 0.998 & 74 & 98.6 \\
\hline
\end{tabular}

a Yield corrected by GC-FID purity. ${ }^{b}$ Analyzed by GC-FID. ${ }^{c}$ Yield and purity obtained in a separated reaction, after $48 \mathrm{~h}$. 


\section{Coordination of complexes $R h_{2} L_{4}$ by 1,4-dioxane. Equilibrium constants and speciation.}

\subsection{Equilibrium constants - Spectrophotometric titration}

Spectrophotometric titrations were performed with a J\&M diode array spectrometer (Tidas series) connected to an external computer. In a typical experiment, $10 \mathrm{~cm}^{3}$ of dirhodium tetracarboxylate complex in chloroform $\left(6 \cdot 10^{-3} \mathrm{~mol} \cdot \mathrm{dm}^{-3}\right)$ were titrated at $293 \mathrm{~K}$ with a solution of 1,4 -dioxane $\left(0.12 \mathrm{~mol} \cdot \mathrm{dm}^{-3}\right)$ in chloroform. After each addition of $25 \mu \mathrm{L}$, the absorbance was recorded using a Hellma optrode (optical path length $0.5 \mathrm{~cm}$ ) immersed in the thermostated titration vessel and connected to the spectrometer. Mathematical treatment of the spectrophotometric titrations was performed with factor analysis and with the ReactLab Equilibria program (http://iplusconsulting.com/products/reactlab-equilibria/). Due to the limitation of Excel to display only about 120 series of data on a graph, 2/3 of the 300 recorded spectra per experiment are not shown.

\subsection{Speciation Graphs}

Speciation graphs were generated using a dedicated software, with the equilibrium constants found in the previous study. Software: HySS Version 4.0.21 (Hyperquad Simulation and Speciation). ${ }^{3}$

Model: $\quad \begin{array}{ll}\mathrm{M}+\mathrm{B}=\mathrm{MB} & \beta_{1,1}^{\mathrm{M}, \mathrm{B}} \\ & \mathrm{M}+2 \mathrm{~B}=\mathrm{MB}_{2} \quad \beta_{1,2}^{\mathrm{M}, \mathrm{B}}\end{array}$

Parameter: Initial concentration $M_{\text {tot }}=0.006$; final concentration $M_{\text {tot }}=0.006 \mathrm{M}$; initial concentration 1,4-dioxane $=0 \mathrm{M}$; final centration 1,4-dioxane $11.7 \mathrm{M}$ ( $\max 1,4$-dioxane concentration).

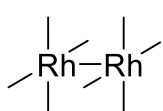

$\mathrm{Rh}_{2} \mathrm{~L}_{4}$

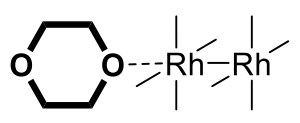

$\mathrm{Rh}_{2} \mathrm{~L}_{4}(\mathbf{B})$

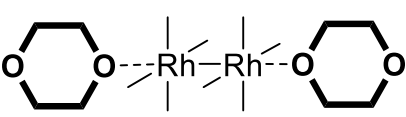

$\mathrm{Rh}_{2} \mathrm{~L}_{4}(\mathbf{B})_{2}$

Figure S5 Dirhodium species in the presence of 1,4-dioxane 


\section{Example of titration analysis with $\mathrm{Rh}_{2}(\mathrm{Oct})_{4}$ complex $2 \mathrm{~b}$ and 1,4-dioxane 3}

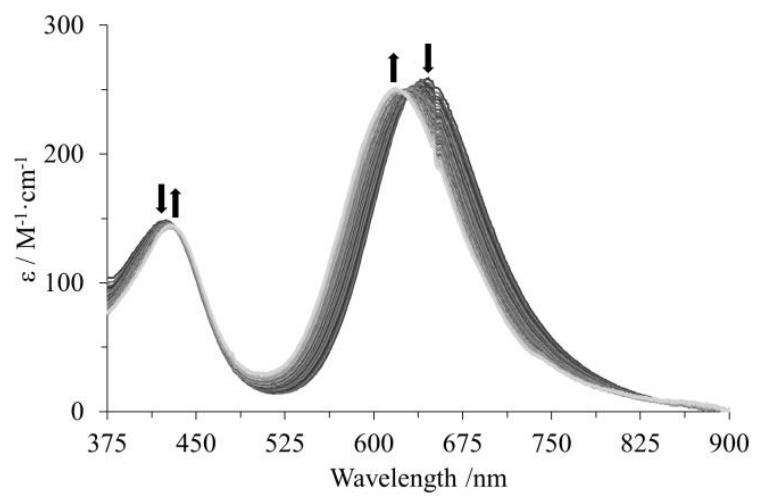

Figure $\mathbf{S 6}$ Spectra from 0.00 to 10.30 equiv of $\mathbf{L}$

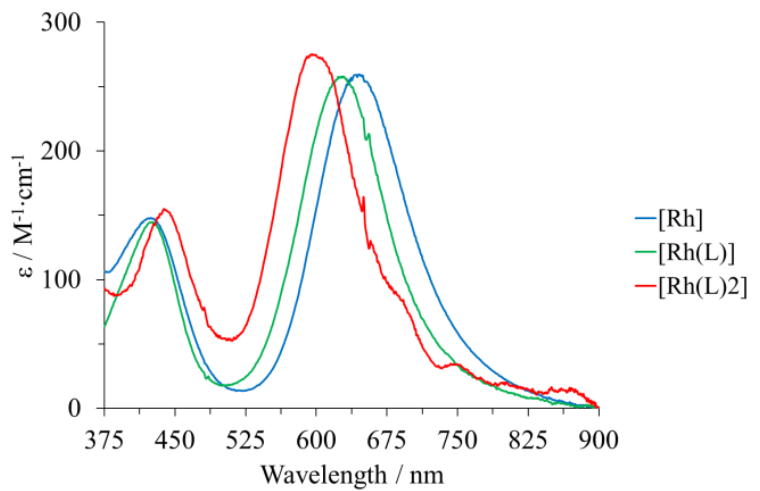

Figure S8 Reconstructed spectra (ReactLab).

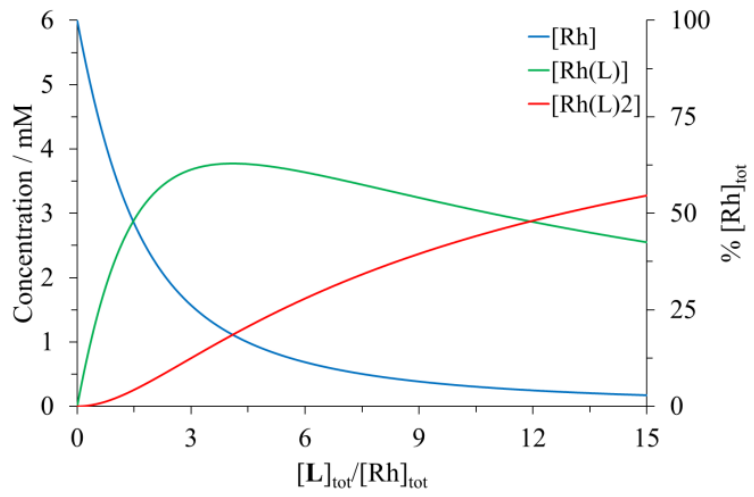

Figure S10 Speciation from 0 to 15 equiv of $\mathbf{L}$.

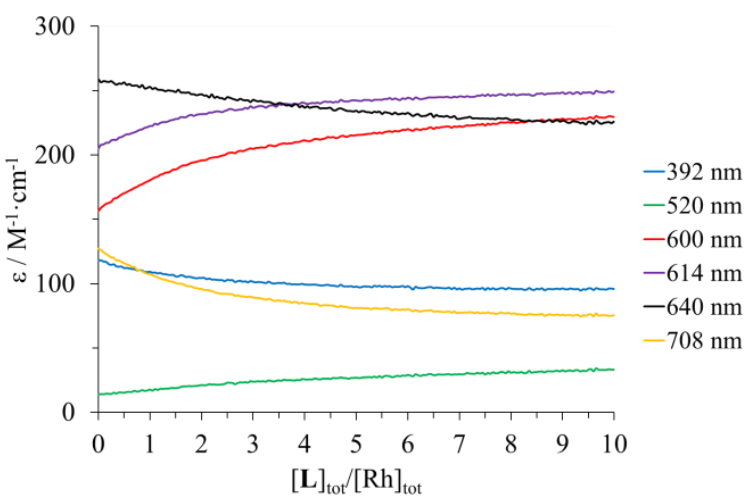

Figure S7 Evolution of $\varepsilon$ at different wavelengths

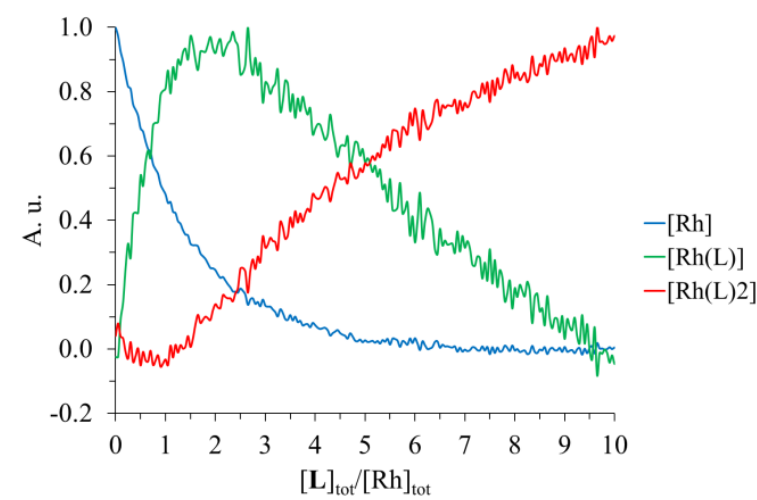

Figure S9 EFA (ReactLab).

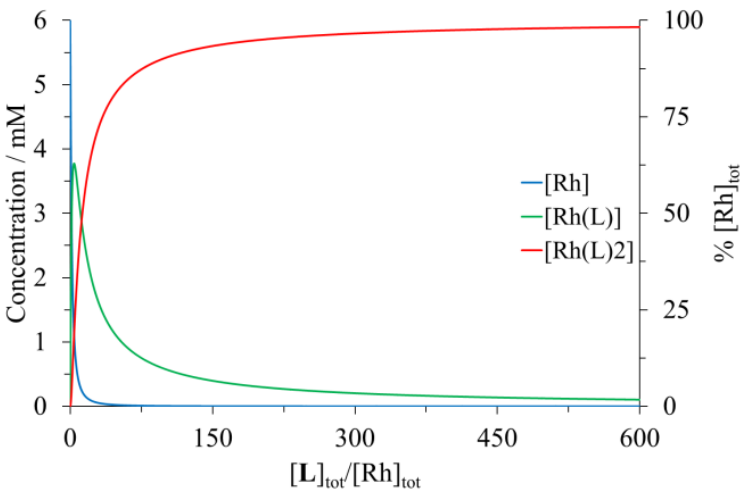

Figure S11 Speciation from 0 to 600 equiv of $\mathbf{L}$ (Hyss).

$$
\begin{array}{ll}
\log \left(\beta_{1,1}^{\mathrm{Rh}, \mathbf{L}}\right)=2.262(2) & K_{1}=183 \\
\log \left(\beta_{1,2}^{\mathrm{Rh}, \mathbf{L}}\right)=3.462(4) & K_{2}=16
\end{array}
$$

ssq : 0.19

$\sigma_{\mathrm{r}}: 1.19 \cdot 10^{-3}$ 


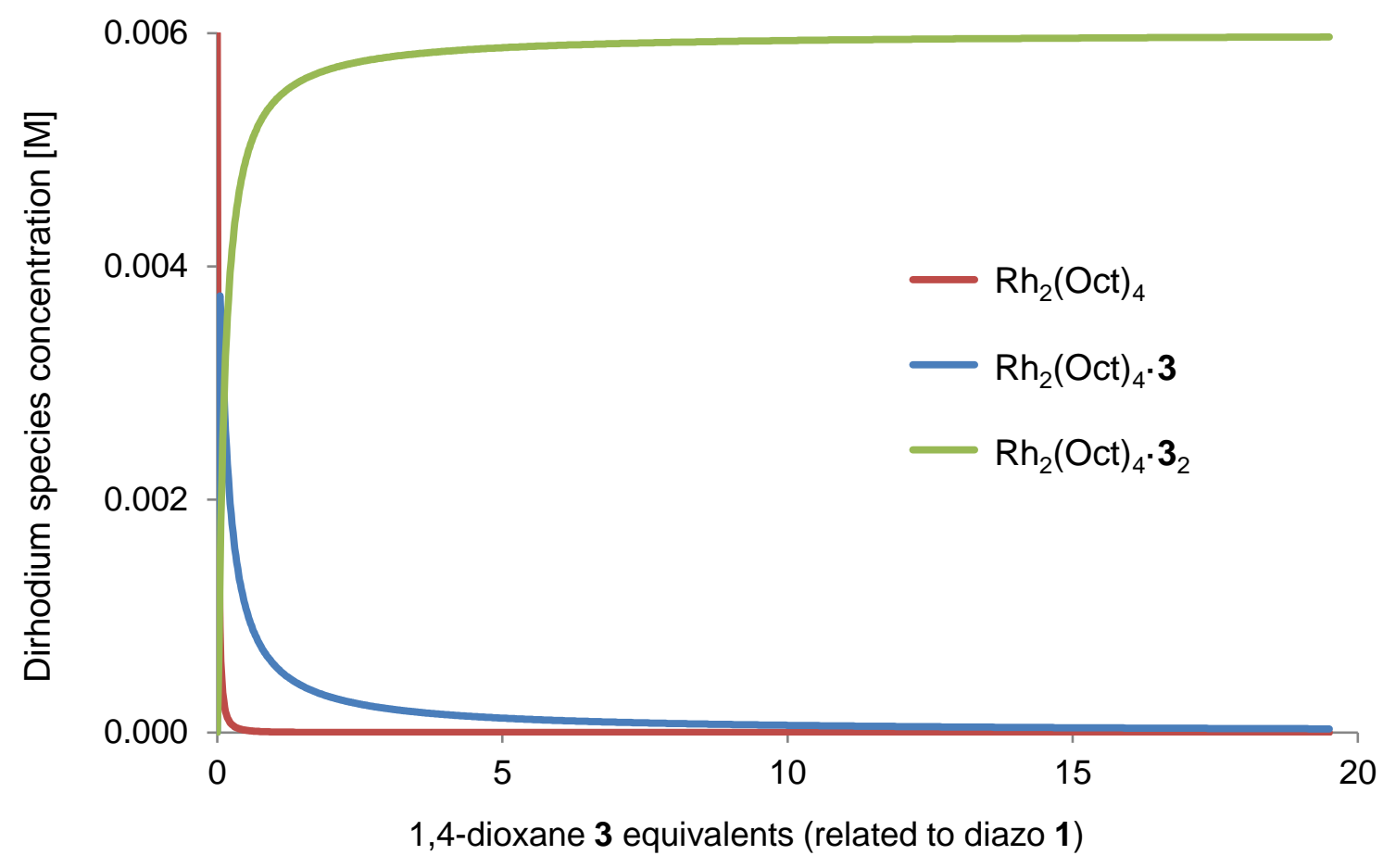

Figure S12 Speciation for $\mathrm{Rh}_{2}(\mathrm{Oct})_{4}$ with 1,4-dioxane 3; $\mathrm{M}_{\mathrm{tot}}=0.006 \mathrm{M}$.

Table S4 Concentration of $\mathrm{Rh}_{2}(\mathrm{Oct})_{4}$ complexes at a fixed amount of 1,4-dioxane 3 .

\begin{tabular}{ccccc}
\hline Entry & 3 equiv & $\mathrm{Rh}_{2}(\mathrm{Oct})_{4}$ & $\mathrm{Rh}_{2}(\mathrm{Oct})_{4} \cdot \mathbf{3}$ & $\mathrm{Rh}_{2}(\mathrm{Oct})_{4} \cdot \mathbf{3}_{2}$ \\
\hline 1 & 6.0 & $0.0026 \%$ & $1.7 \%$ & $98.3 \%$ \\
2 & 19.7 & $<0.001 \%$ & $0.5 \%$ & $99.5 \%$ \\
\hline
\end{tabular}




\section{Example of titration analysis with $\mathrm{Rh}_{2}(R \text {-DOSP })_{4}$ complex $2 \mathrm{c}$ and 1,4-dioxane 3}

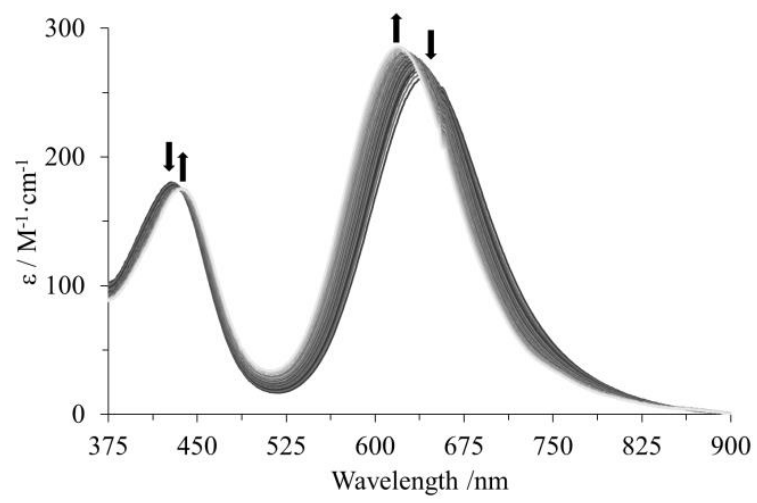

Figure S13 Spectra from 0.00 to 12.55 equiv of $\mathbf{L}$

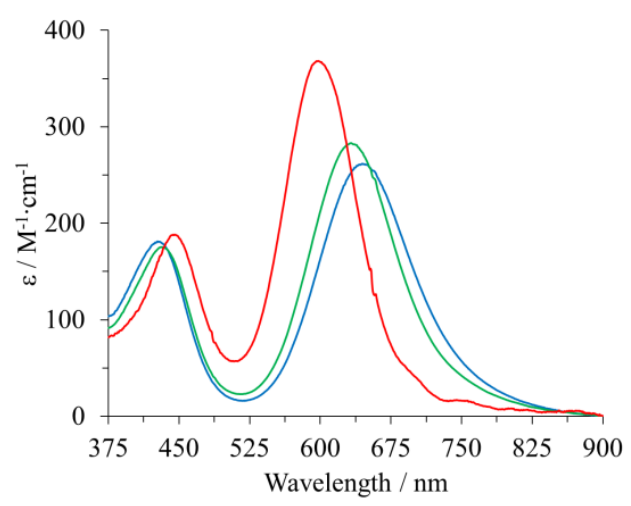

Figure S15 Reconstructed spectra (ReactLab).

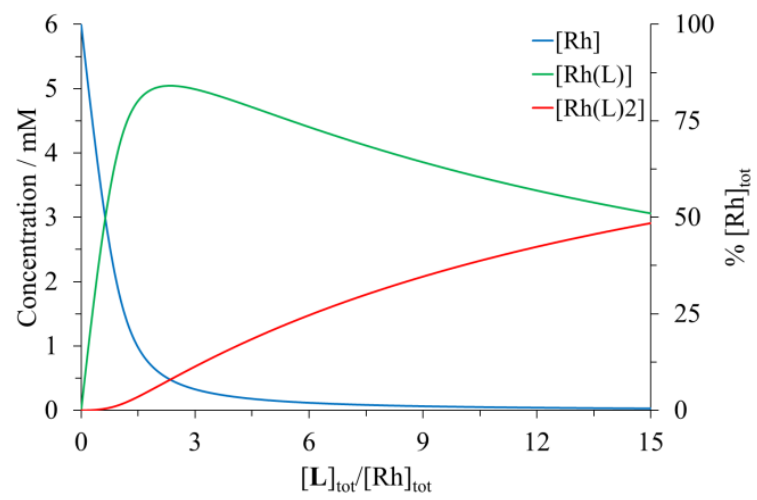

Figure $\mathbf{S} 17$ Speciation from 0 to 15 equiv of $\mathbf{L}$.

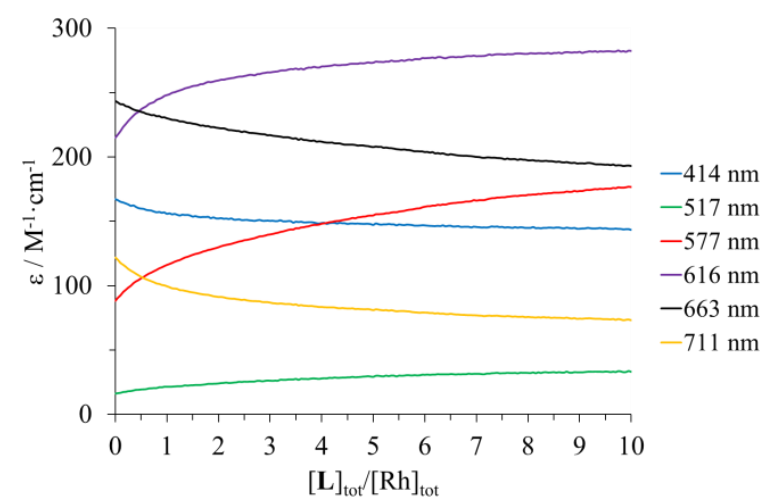

Figure S14 Evolution of $\varepsilon$ at different wavelengths

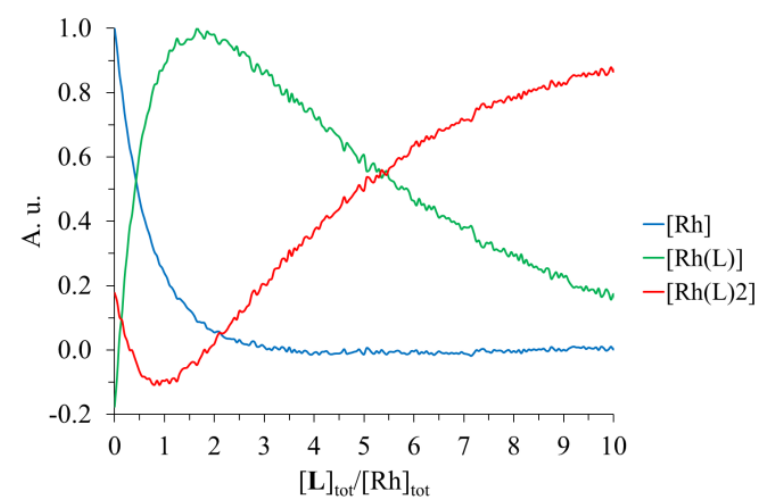

Figure S16 EFA (ReactLab).

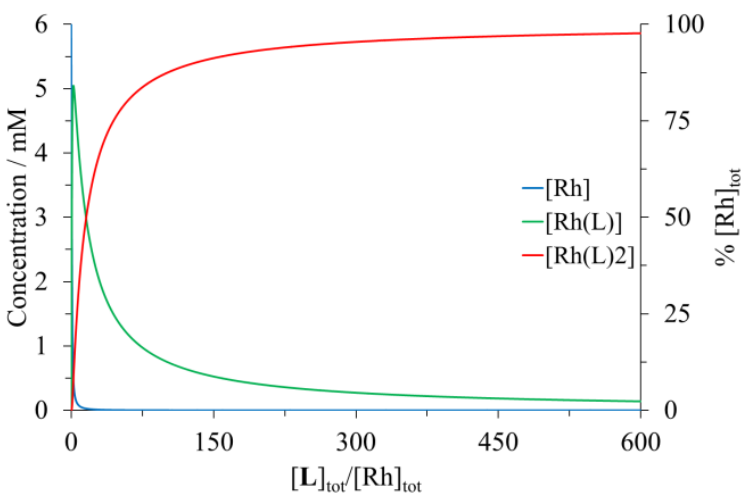

Figure $\mathbf{S} 18$ Speciation from 0 to 600 equiv of $\mathbf{L}$ (Hyss).

$$
\begin{array}{ll}
\log \left(\beta_{1,1}^{\mathrm{Rh}, \mathrm{L}}\right)=3.117(2) & K_{1}=1309 \\
\log \left(\beta_{1,2}^{\mathrm{Rh}, \mathrm{L}}\right)=4.186(3) & K_{2}=12
\end{array}
$$

ssq : 0.31

$\sigma_{\mathrm{r}}: 1.27 \cdot 10^{-3}$ 


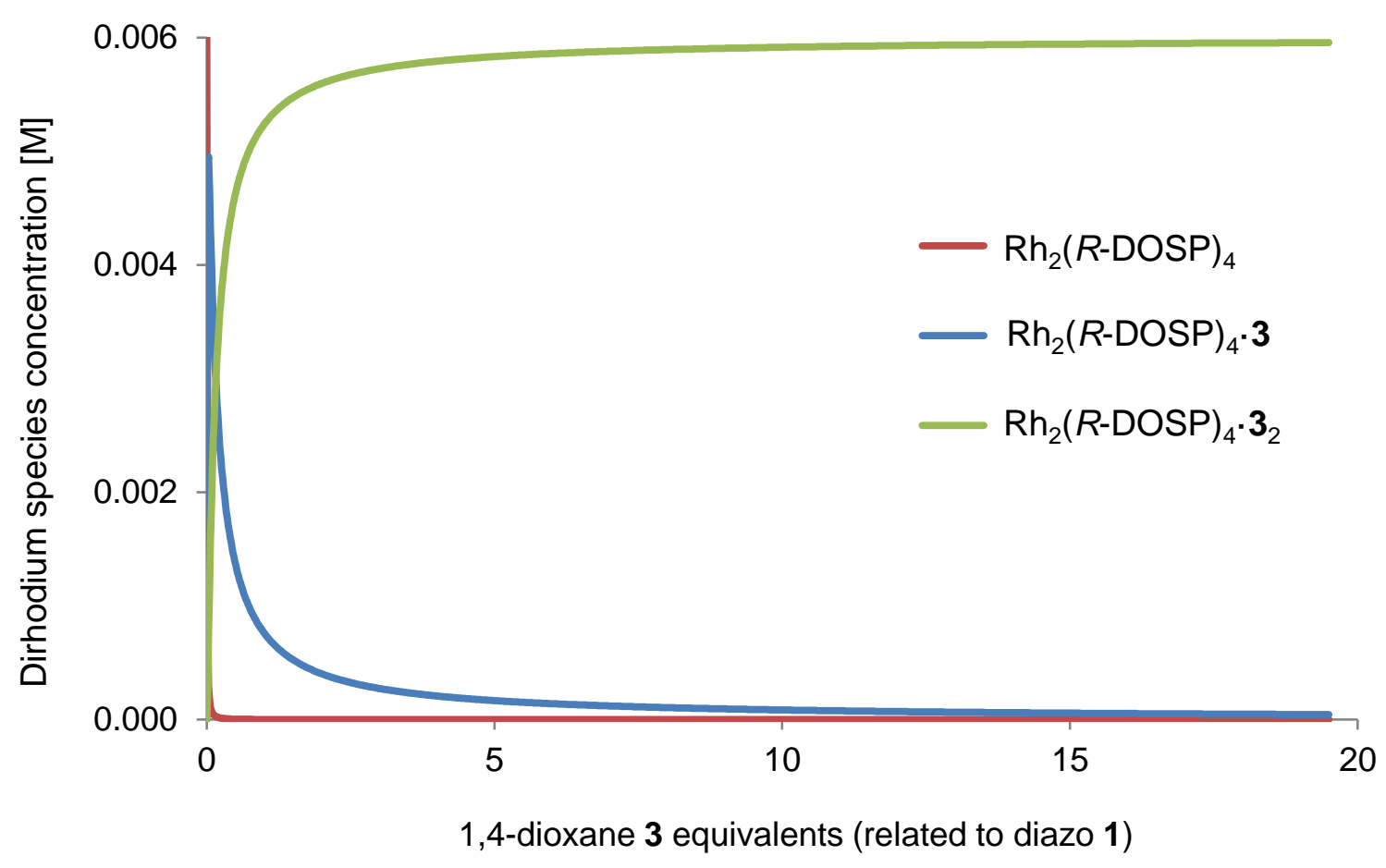

Figure S19 Speciation for $\mathrm{Rh}_{2}(R \text {-DOSP })_{4}$ with 1,4-dioxane 3; $\mathrm{M}_{\text {tot }}=0.006 \mathrm{M}$.

Table S5 Concentration of $\mathrm{Rh}_{2}(R \text {-DOSP })_{4}$ complexes at fixed amounts of 1,4-dioxane 3 .

\begin{tabular}{ccccc}
\hline Entry & 3 equiv & $\mathrm{Rh}_{2}(R \text {-DOSP })_{4}$ & $\mathrm{Rh}_{2}(R \text {-DOSP })_{4} \cdot \mathbf{3}$ & $\mathrm{Rh}_{2}(R \text {-DOSP })_{4} \cdot \mathbf{3}_{2}$ \\
\hline 1 & 6.0 & $<0.001 \%$ & $2.3 \%$ & $97.7 \%$ \\
2 & 19.7 & $<0.001 \%$ & $0.7 \%$ & $99.3 \%$ \\
\hline
\end{tabular}




\section{Example of titration analysis with $\mathrm{Rh}_{2}(\mathrm{~S}-\mathrm{PTTL})_{4}$ complex $2 \mathrm{~d}$ and 1,4-dioxane 3}

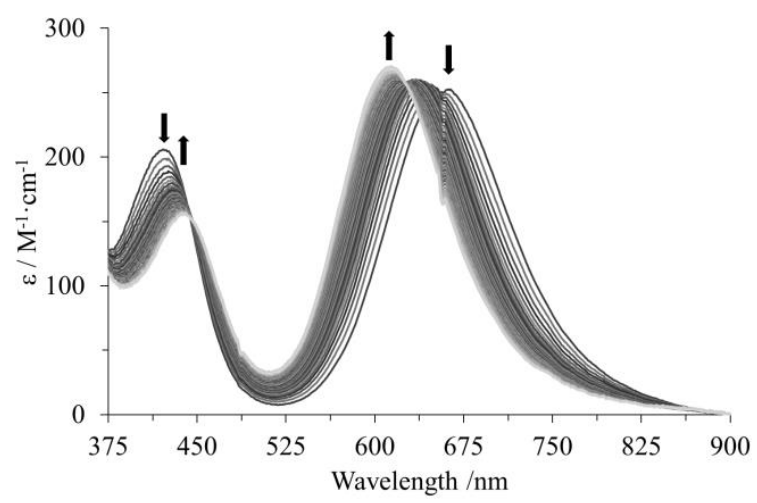

Figure S20 Spectra from 0.00 to 17.05 equiv of $\mathbf{L}$

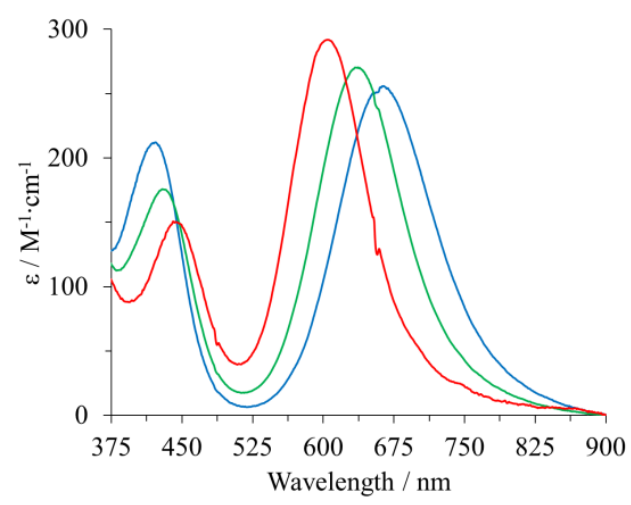

Figure S22 Reconstructed spectra (ReactLab).

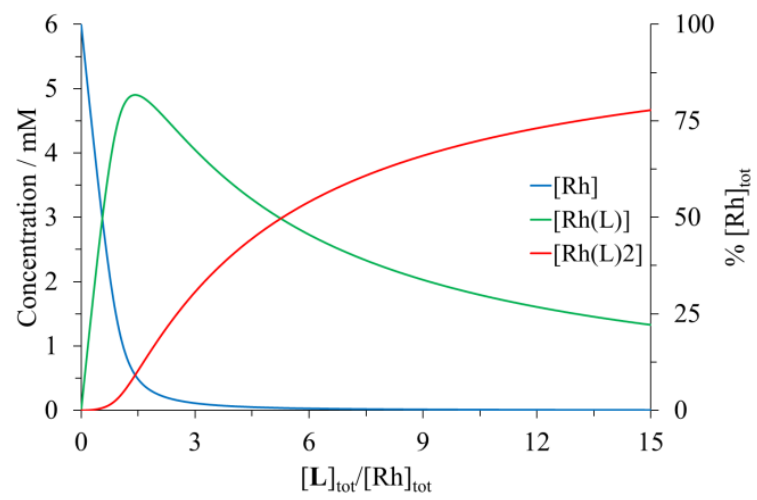

Figure S24 Speciation from 0 to 15 equiv of $\mathbf{L}$.

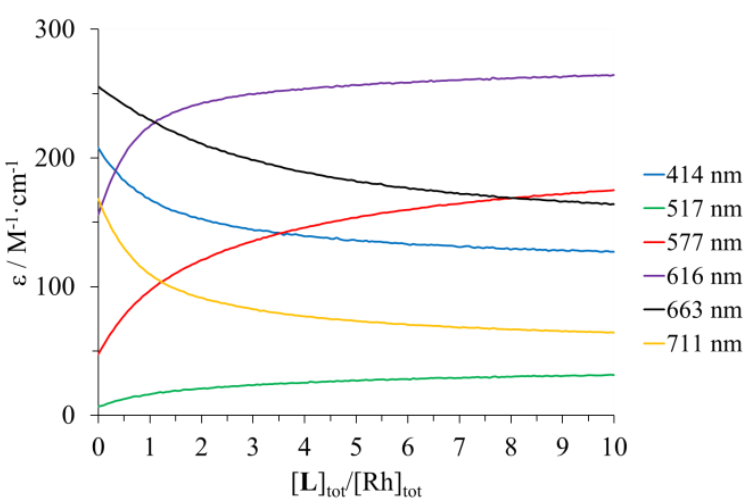

Figure S21 Evolution of $\varepsilon$ at different wavelengths

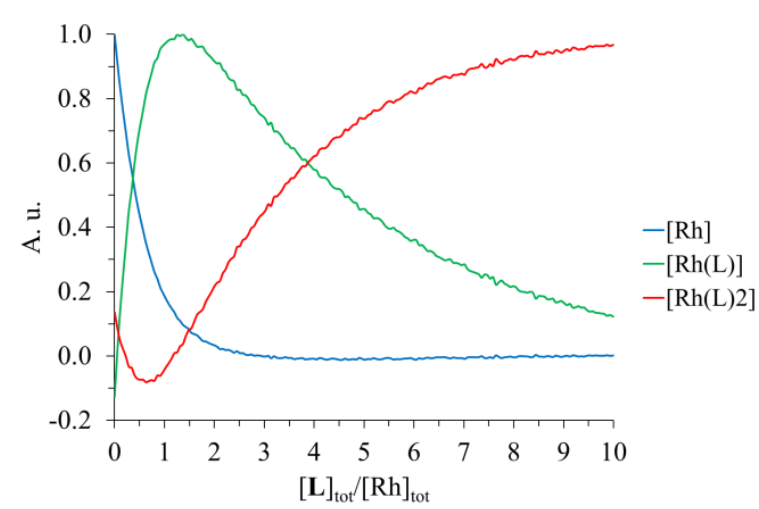

Figure S23 EFA (ReactLab).

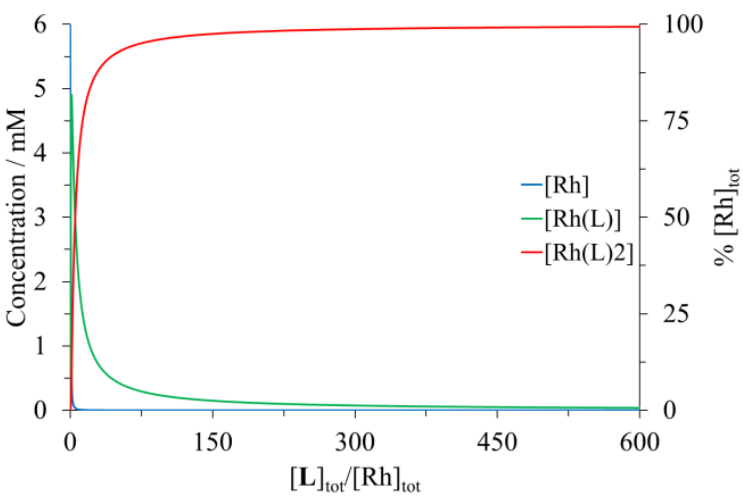

Figure S25 Speciation from 0 to 600 equiv of $\mathbf{L}$ (Hyss).

$$
\begin{array}{ll}
\log \left(\beta_{1,1}^{\mathrm{Rh}, \mathbf{L}}\right)=3.549(2) & K_{1}=3540 \\
\log \left(\beta_{1,2}^{\mathrm{Rh}, \mathbf{L}}\right)=5.195(3) & K_{2}=44
\end{array}
$$

ssq : 0.53

$\sigma_{\mathrm{r}}: 1.65 \cdot 10^{-3}$ 


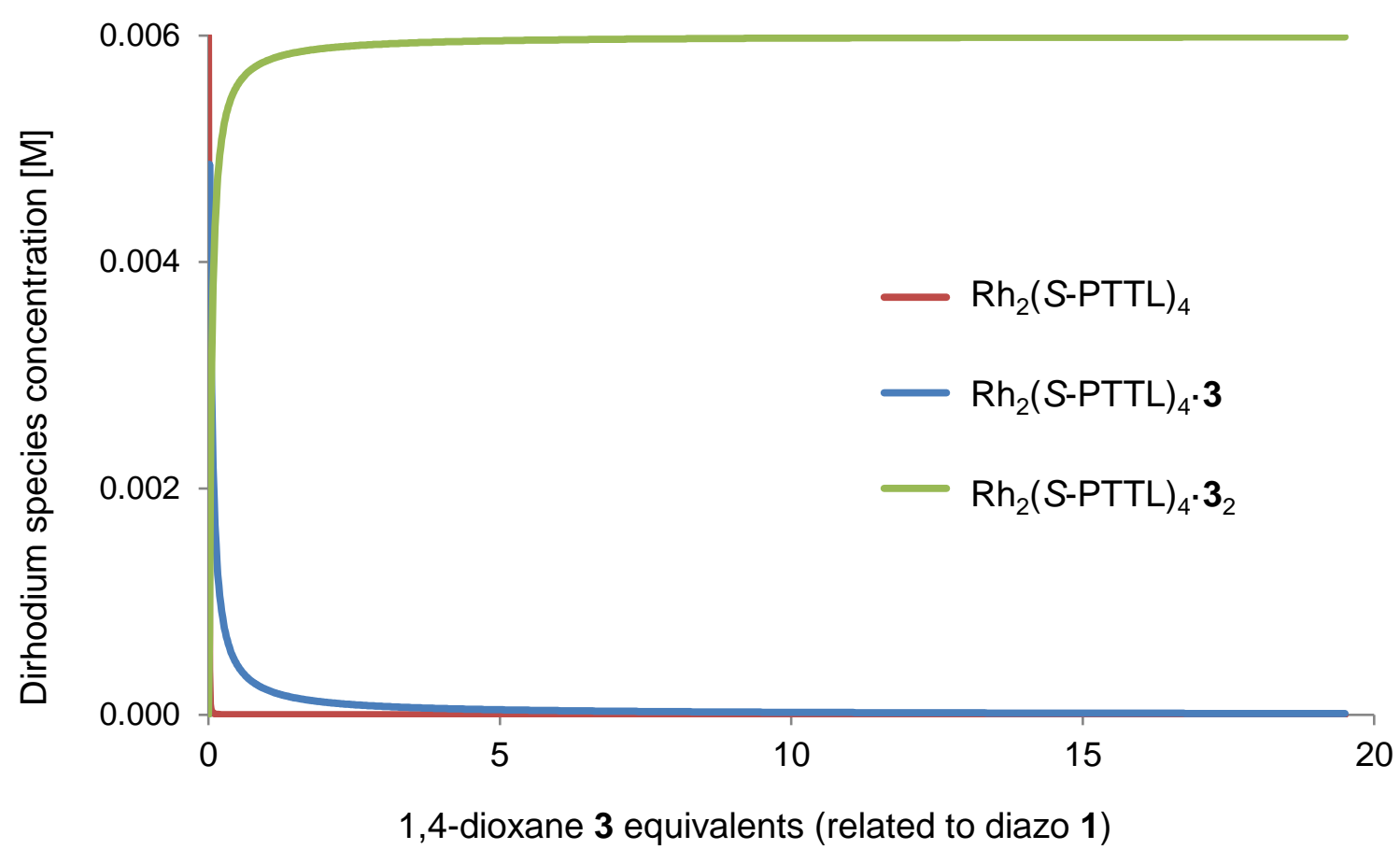

Figure S26 Speciation for $\mathrm{Rh}_{2}(\mathrm{~S}-\mathrm{PTTL})_{4}$ with 1,4-dioxane 3; $\mathrm{M}_{\mathrm{tot}}=0.006 \mathrm{M}$.

Table S6 Concentration of $\mathrm{Rh}_{2}(S$-PTTL) 4 complexes at fixed amounts of 1,4-dioxane 3.

\begin{tabular}{ccccc}
\hline Entry & 3 equiv & $\mathrm{Rh}_{2}(\mathrm{~S}-\mathrm{PTTL})_{4}$ & $\mathrm{Rh}_{2}(\mathrm{~S}-\mathrm{PTTL})_{4} \cdot \mathbf{3}$ & $\mathrm{Rh}_{2}(\mathrm{~S}-\mathrm{PTTL})_{4} \cdot \mathbf{3}_{2}$ \\
\hline 1 & 6.0 & $<0.001 \%$ & $0.6 \%$ & $99.4 \%$ \\
2 & 19.7 & $<0.001 \%$ & $0.19 \%$ & $99.8 \%$ \\
\hline
\end{tabular}




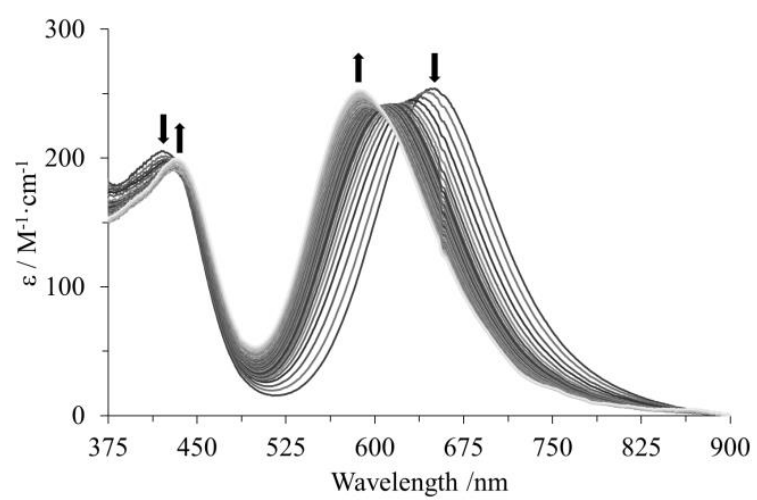

Figure S27 Spectra from 0.00 to 12.55 equiv of $\mathbf{L}$

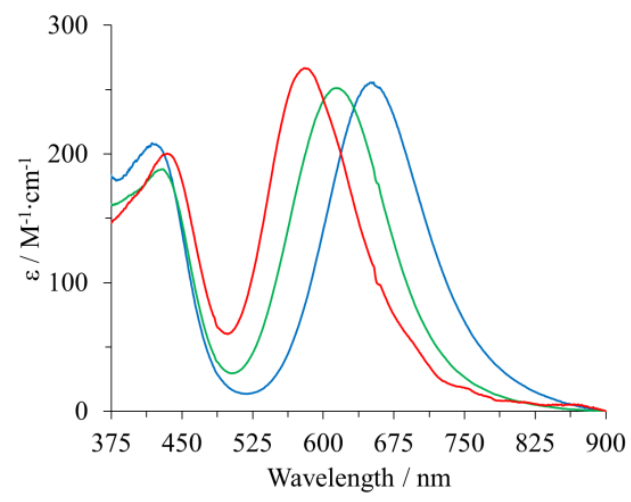

Figure S29 Reconstructed spectra (ReactLab).

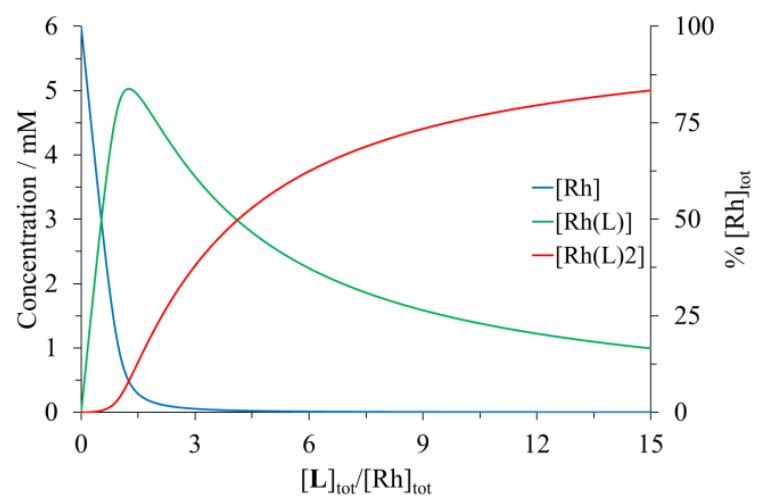

Figure S31 Speciation from 0 to 15 equiv of $\mathbf{L}$.

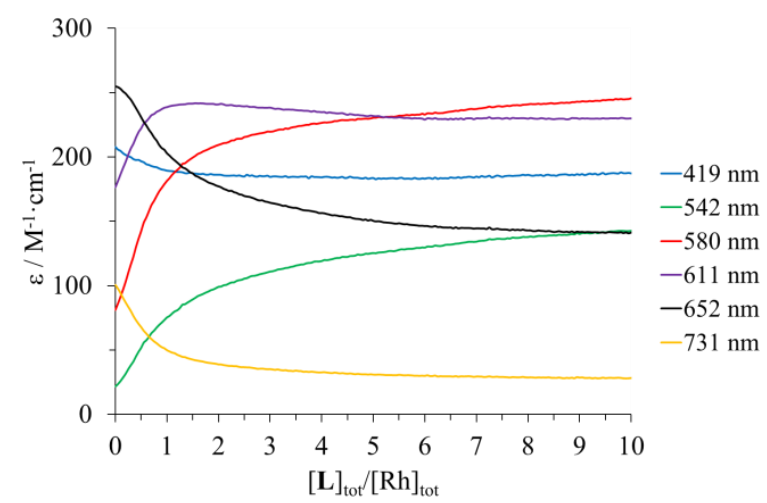

Figure $\mathbf{S 2 8}$ Evolution of $\varepsilon$ at different wavelengths

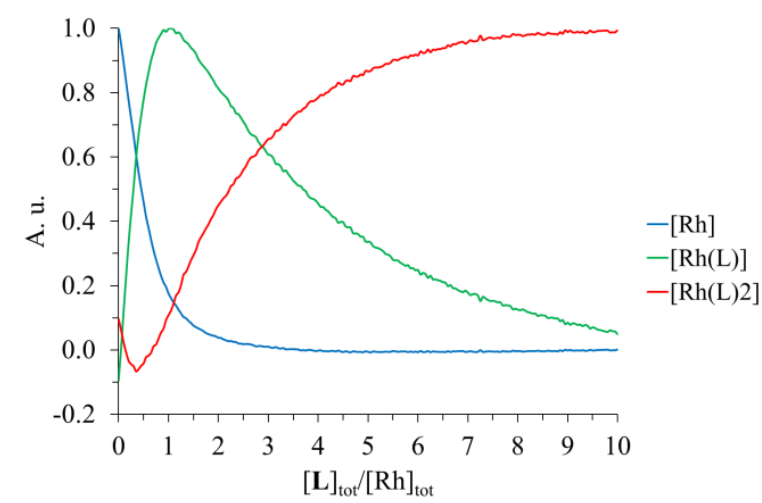

Figure S30 EFA (ReactLab).

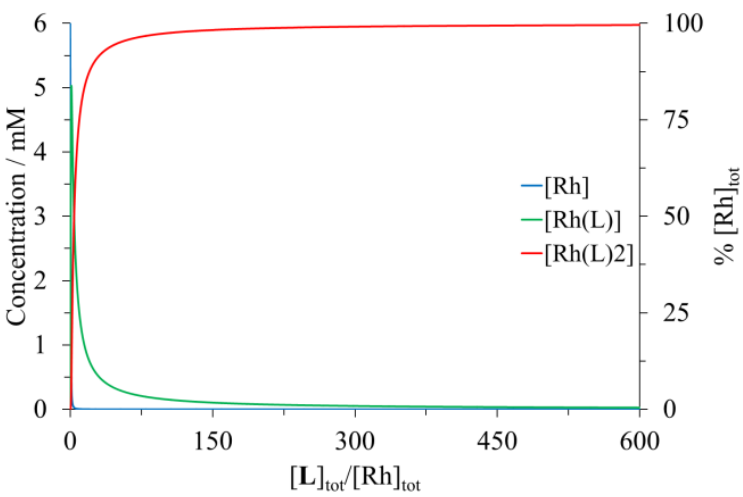

Figure S32 Speciation from 0 to 600 equiv of $\mathbf{L}$ (Hyss).

$$
\begin{array}{ll}
\log \left(\beta_{1,1}^{\mathrm{Rh}, \mathbf{L}}\right)=3.835(4) & K_{1}=6839 \\
\log \left(\beta_{1,2}^{\mathrm{Rh}, \mathbf{L}}\right)=5.639(5) & K_{2}=64
\end{array}
$$

ssq : 2.67

$\sigma_{\mathrm{r}}: 3.72 \cdot 10^{-3}$ 


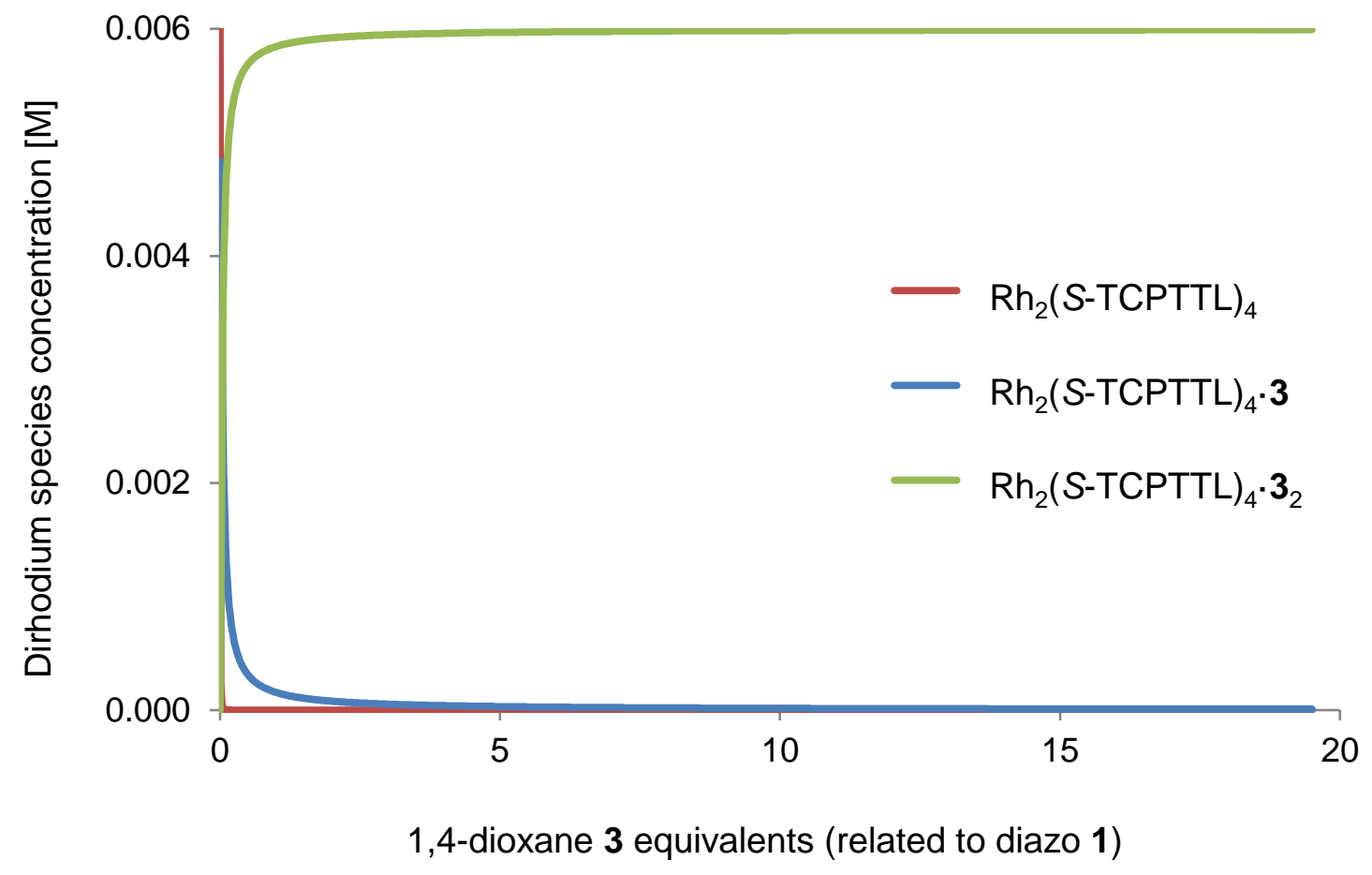

Figure S33 Speciation for $\mathrm{Rh}_{2}(\mathrm{~S}$-TCPTTL) 4 with 1,4-dioxane 3; Mtot $=0.006 \mathrm{M}$.

Table S7 Concentration of $\mathrm{Rh}_{2}(\mathrm{~S} \text {-TCPTTL })_{4}$ complexes at fixed amounts of 1,4-dioxane 3 .

\begin{tabular}{ccccc}
\hline Entry & 3 equiv & $\mathrm{Rh}_{2}(S-\mathrm{TCPTTL})_{4}$ & $\mathrm{Rh}_{2}(\mathrm{~S} \text {-TCPTTL })_{4} \cdot \mathbf{3}$ & $\mathrm{Rh}_{2}(\mathrm{~S} \text {-TCPTTL })_{4} \cdot \mathbf{3}_{2}$ \\
\hline 1 & 6.0 & $<0.001 \%$ & $0.4 \%$ & $99.6 \%$ \\
2 & 19.7 & $<0.001 \%$ & $0.1 \%$ & $99.9 \%$ \\
\hline
\end{tabular}




\section{Kinetics of diazo decomposition varying the amount of 1,4- dioxane}

\subsection{Experiment with $\mathrm{Rh}_{2}(\mathrm{Oct})_{4} 2 \mathrm{~b}$}

$\mathrm{Rh}_{2}(\mathrm{Oct})_{4} \mathbf{2 b}$ (1.0 mol\%), 1,4-dioxane 3 (from 19.6 to 0.1 equiv), $\mathrm{CHCl}_{3}$ (to reach $V_{\text {tot }}=1.75$ $\mathrm{ml}$ ) were mixed into a temperature controlled $\left(25^{\circ} \mathrm{C}\right)$ schlenk tube connected to a $\mathrm{N}_{2}$ line. The ReactIR $\circledast$ probe was introduced in the solution and a blank spectrum recorded. Diazo 1 (150 $\mathrm{mg}, 1.06 \mathrm{mmol}, 1.0$ equiv) was added to the mixture and one IR spectra collected each minute for ca. $20 \mathrm{~h}$.

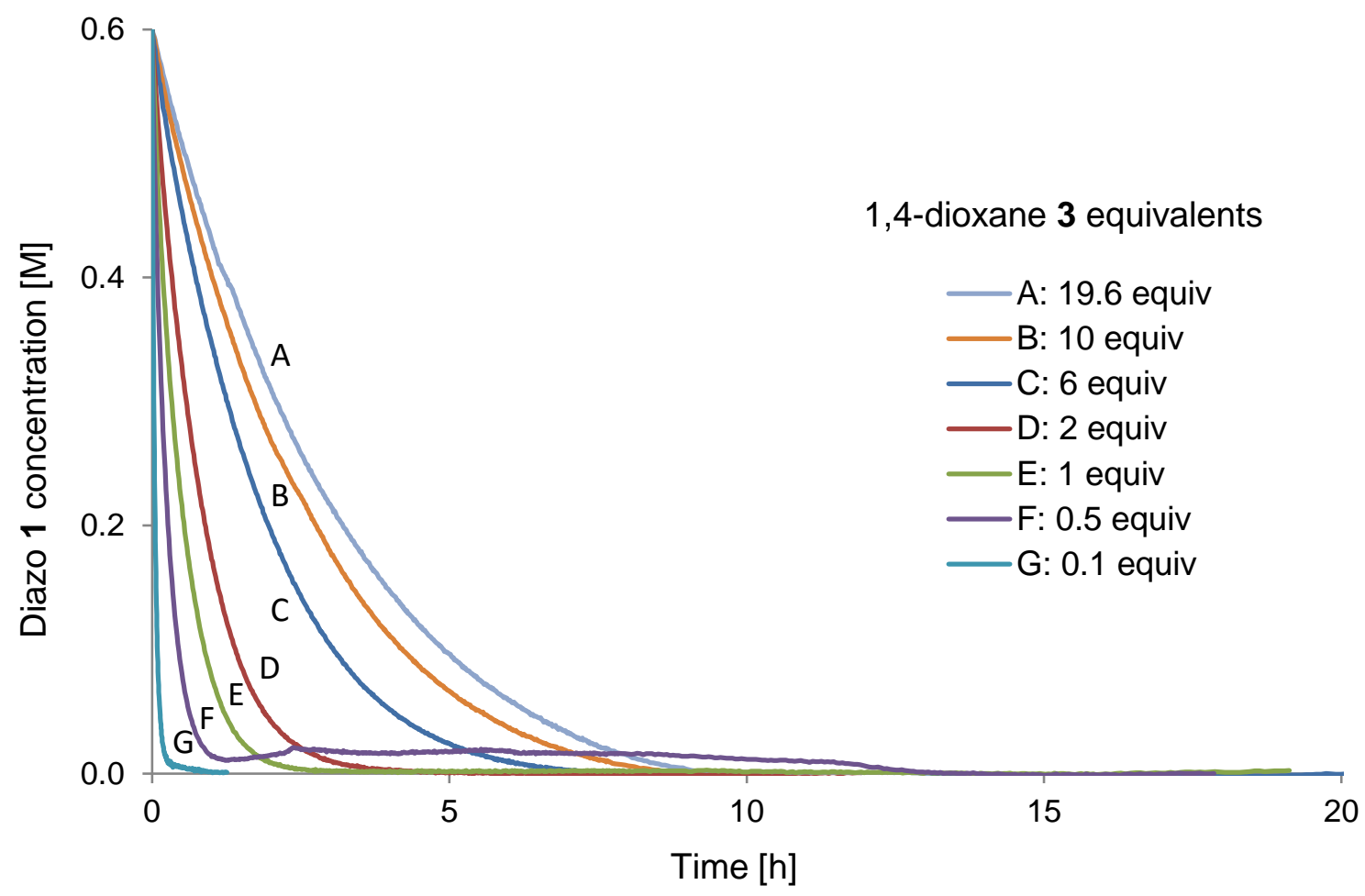

Figure S34 Diazo 1 concentration [M] evolution during reaction time [h] using 1.0 mol\% of $\mathrm{Rh}_{2}(\mathrm{Oct})_{4}$ $\mathbf{2 b}$ and varying the equivalents of 1,4-dioxane $\mathbf{3}$. (Trends from $2146 \mathrm{~cm}^{-1} \mathrm{IR}$ intensity, normalized at to $=0.6 \mathrm{M}$ for diazo 1 ). 


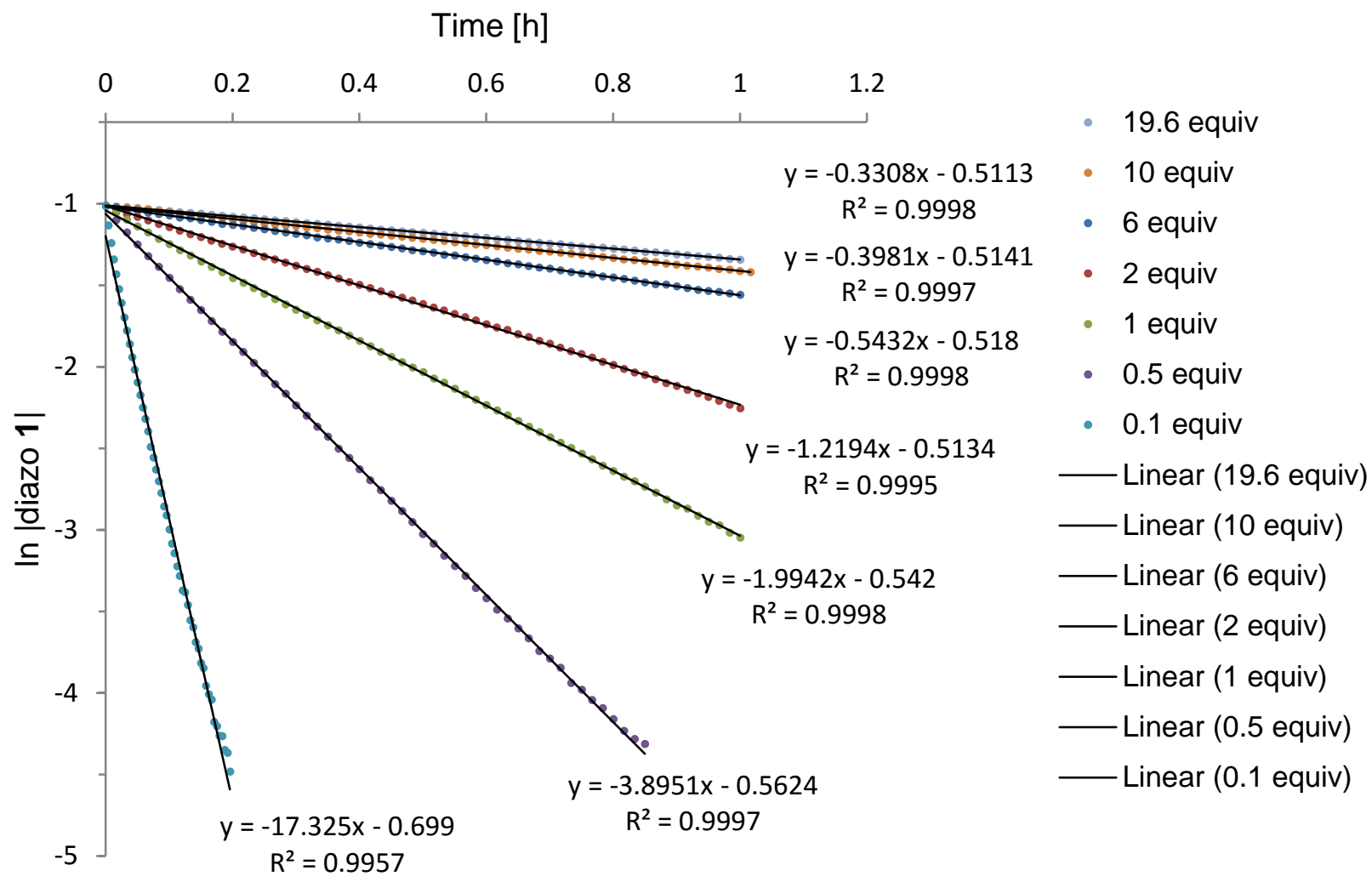

Figure S35 First order linearization of diazo 1 concentration and corresponding trend lines. Experiments using 1.0 mol\% of $\mathrm{Rh}_{2}(\mathrm{Oct})_{4} \mathbf{2} \mathbf{b}$ varying the equivalents of 1,4 -dioxane.

Table S8 Pseudo-first order kinetic constants $\boldsymbol{k}_{1}$ for the decomposition of diazo 1 using $1.0 \mathrm{~mol} \%$ of $\mathrm{Rh}_{2}(\mathrm{Oct})_{4} \mathbf{2} \mathbf{b}$ varying the equivalents of 1,4 -dioxane $\mathbf{3}$.

\begin{tabular}{cccc}
\hline Entry & 1.4-dioxane $\mathbf{3}$ equiv & $\boldsymbol{k}_{\mathbf{1}}\left[\mathbf{h}^{-1}\right]$ & $R^{2}$ \\
\hline 1 & 19.6 & $\mathbf{0 . 3 3}$ & 0.998 \\
2 & 10 & $\mathbf{0 . 3 9}$ & 0.999 \\
3 & 6 & $\mathbf{0 . 5 4}$ & 0.999 \\
4 & 2 & $\mathbf{1 . 2}$ & 0.998 \\
5 & 1 & $\mathbf{2 . 0}$ & 0.999 \\
6 & 0.5 & $\mathbf{3 . 9}$ & 0.999 \\
7 & 0.1 & $\mathbf{1 7 . 3}$ & 0.996 \\
\hline
\end{tabular}




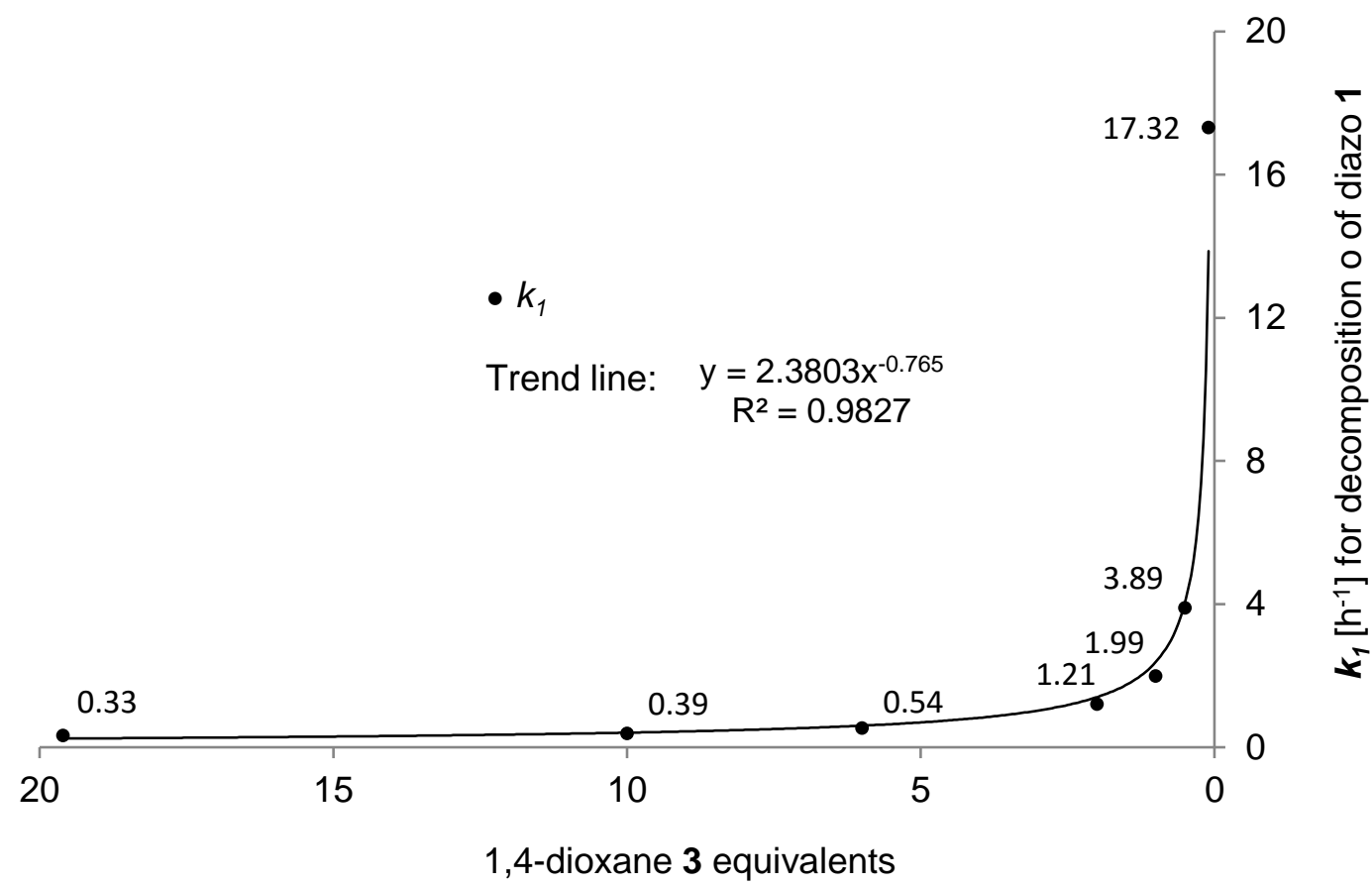

Figure S36 Kinetic constants for the consumption of diazo 1 compared to the equivalents of 1,4dioxane $\mathbf{3}$ engaged in the reaction with $1.0 \mathrm{~mol} \%$ of $\mathrm{Rh}_{2}(\mathrm{Oct})_{4} \mathbf{2 b}$. 


\subsection{Experiment with $\mathrm{Rh}_{2}(\mathrm{~S}-\mathrm{PTTL})_{4} \mathbf{2 d}$}

Same as detailed in section 6.1 with $\mathrm{Rh}_{2}(\mathrm{~S}-\mathrm{PTTL})_{4} \mathbf{2 d}$ (from 19.6 to 1.0 equiv).

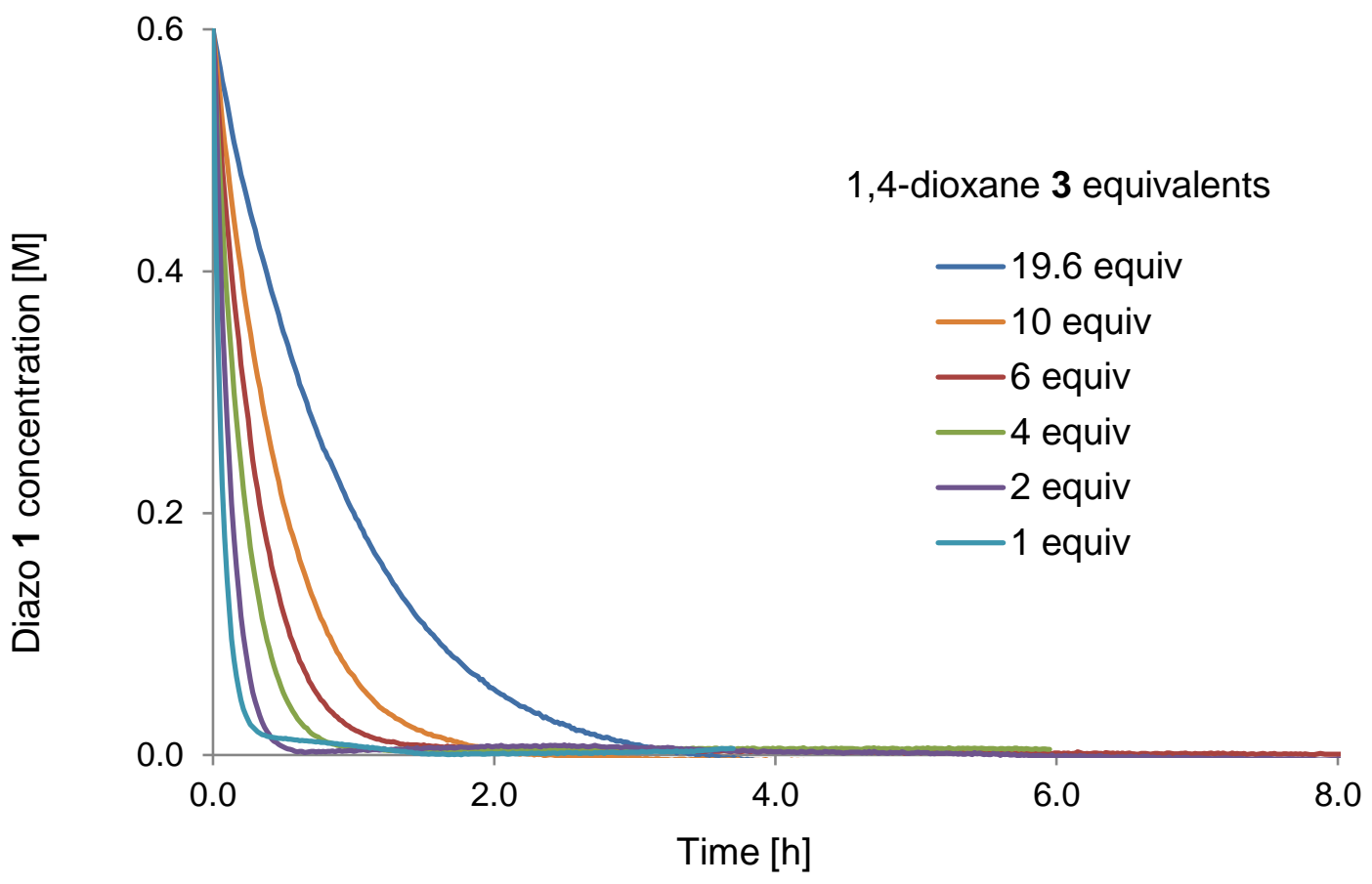

Figure S 37 Diazo 1 concentration [M] evolution during reaction time [h] using $1.0 \mathrm{~mol} \%$ of $\mathrm{Rh}_{2}(\mathrm{~S}$ $\mathrm{PTTL})_{4} \mathbf{2 d}$ and varying the equivalents of 1,4-dioxane 3. (Trends from $2146 \mathrm{~cm}^{-1} \mathrm{IR}$ intensity, normalized at to $=0.6 \mathrm{M}$ for diazo 1 ). 


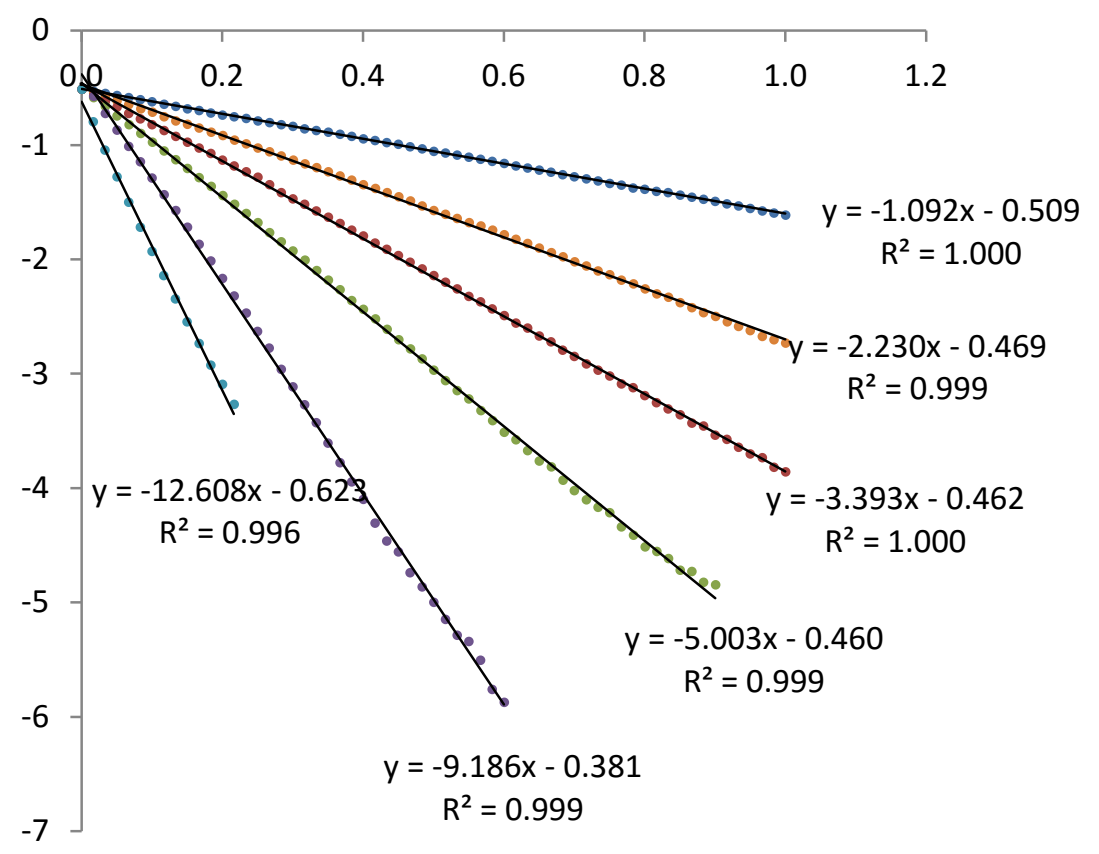

- 19.6 equiv

- 10 equiv

- 6 equiv

- 4 equiv

- 2 equiv

- 1 equiv

_ Linear (19.6 equiv)

_ Linear (10 equiv)

_ Linear (6 equiv)

- Linear (4 equiv)

_Linear (2 equiv)

_ Linear (1 equiv)

Figure S38 First order linearization of diazo 1 concentration and corresponding trend lines.

Experiments using 1.0 mol\% of $\mathrm{Rh}_{2}(S-\mathrm{PTTL})_{4} \mathbf{2 d}$ varying the equivalents of 1,4-dioxane 3.

Table S9 Pseudo-first order kinetic constants $\boldsymbol{k}_{1}$ for the decomposition of diazo 1 using $1.0 \mathrm{~mol} \%$ of $\mathrm{Rh}_{2}(\mathrm{~S}-\mathrm{PTTL})_{4} \mathbf{2 d}$ varying the equivalents of 1,4-dioxane $\mathbf{3}$.

\begin{tabular}{cccc}
\hline Entry & 1.4-dioxane $\mathbf{3}$ equiv & $\boldsymbol{k}_{\mathbf{1}}\left[\mathrm{h}^{-1}\right]$ & $R^{2}$ \\
\hline 1 & 19.6 & $\mathbf{1 . 0 9}$ & 1.000 \\
2 & 10 & $\mathbf{2 . 2 3}$ & 0.999 \\
3 & 6 & $\mathbf{3 . 3 9}$ & 1.000 \\
4 & 4 & $\mathbf{5 . 0 0}$ & 0.999 \\
5 & 2 & $\mathbf{9 . 1 8}$ & 0.999 \\
6 & 1 & $\mathbf{1 2 . 6 1}$ & 0.996 \\
\hline
\end{tabular}




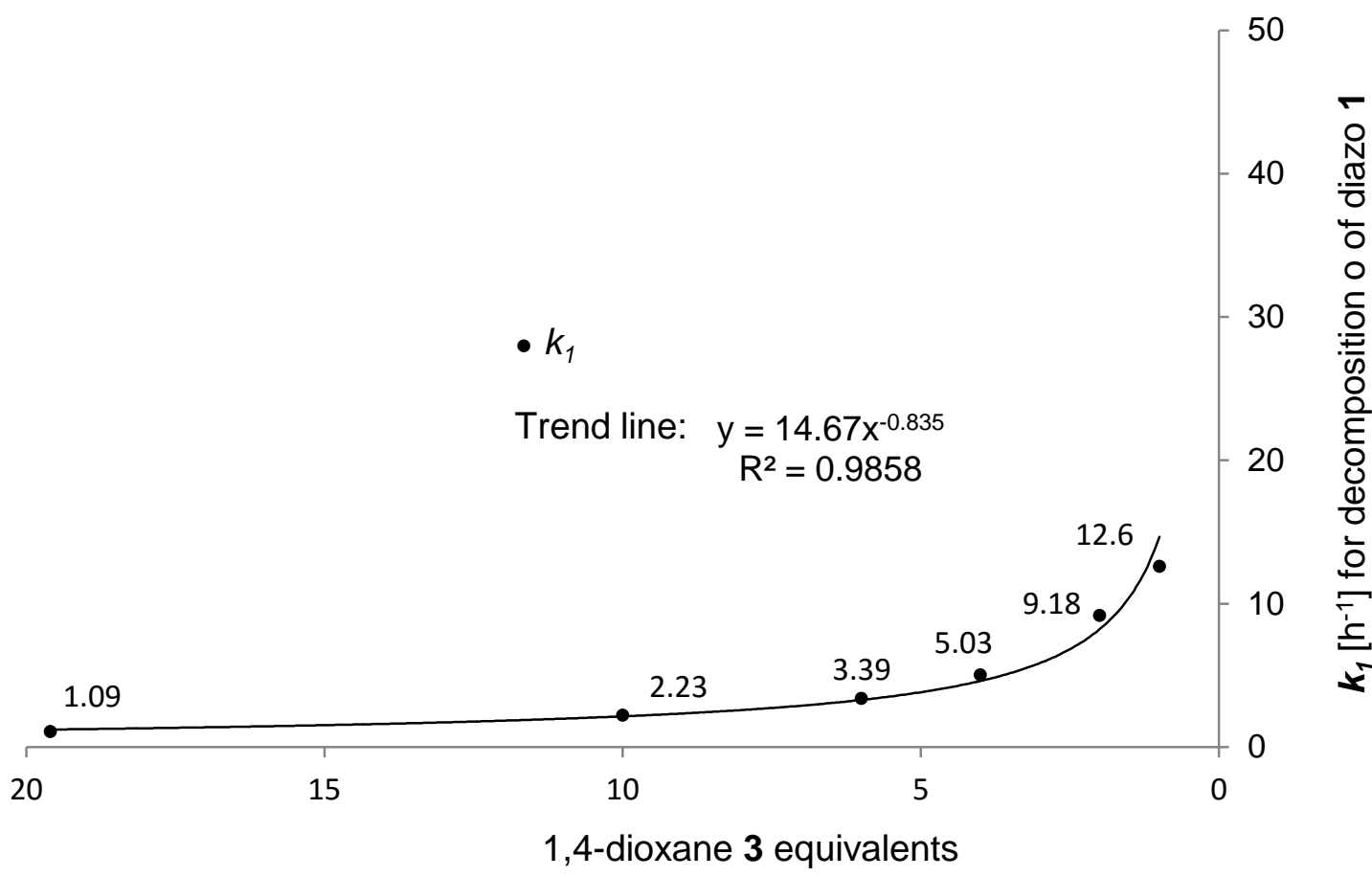

Figure S39 Kinetic constants for the consumption of diazo 1 compared to the equivalents of 1,4dioxane 3 engaged in the reaction with $1.0 \mathrm{~mol} \%$ of $\mathrm{Rh}_{2}(S-\mathrm{PTTL})_{4} \mathbf{2 d}$. 


\subsection{Speciation of $\mathrm{Rh}_{2}(\mathrm{~S}-\mathrm{PTTL})_{4} 2 \mathrm{~d}$ and comparison of $\boldsymbol{k}_{1}$ in relation with the}

equivalents of 1,4-dioxane 3 .

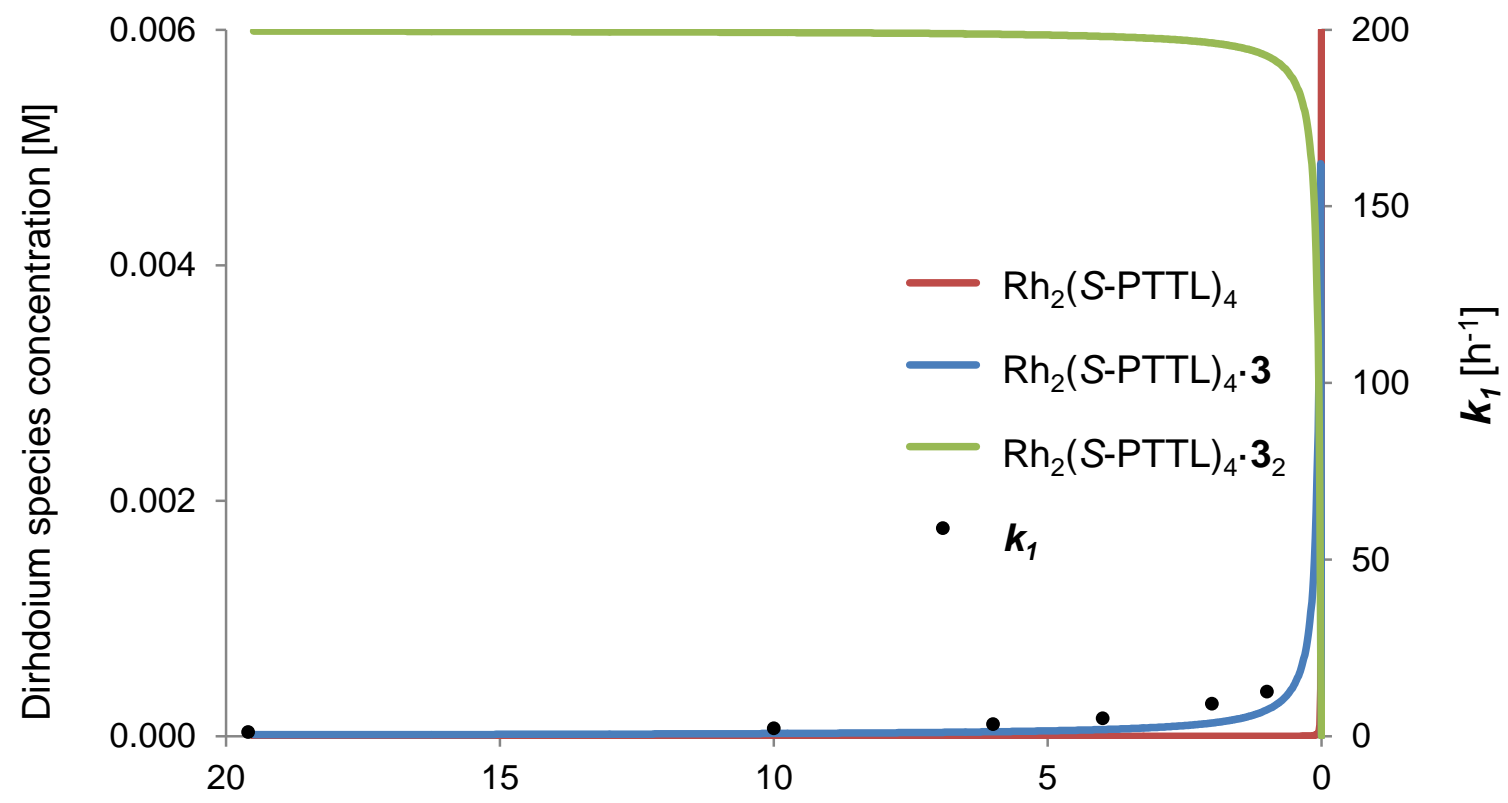

1,4-dioxane 3 equivalents (related to diazo 1)

Figure S40 Kinetic constants $\boldsymbol{k}_{\mathbf{1}}(\cdot)$ for the decomposition of $\mathbf{1}$ in the presence of variable amounts of 3. Speciation of species $\mathrm{Rh}_{2}(S-P T T L)_{4}, \mathrm{Rh}_{2}(S-P T T L) 4.3$ and $R h_{2}(S-P T T L)_{4} \cdot 3_{2}$ : red, blue and green curves respectively. 


\section{Synthesis of cyclohexyl-based catalysts $R_{2}(\mathrm{PTCC})_{4} 2 f$ and $\mathrm{Rh}_{2}\left(\mathrm{TCPTCC}_{4} 2 \mathrm{~g}\right.$}

\subsection{Ligand synthesis}

\section{1-(1,3-dioxoisoindolin-2-yl)cyclohexane-1-carboxylic acid (PTCC)}<smiles></smiles>

From modified literature procedure. ${ }^{4}$ Phthalic anhydride $(5.0 \mathrm{~g}, 33.76 \mathrm{mmol}$, 1.1 equiv) and 1-aminocyclohexanecarboxylic acid $(4.39 \mathrm{~g}, 30.69 \mathrm{mmol}, 1.0$ equiv) were introduced in a flame dried $250 \mathrm{~mL}$ round bottom flask under $\mathrm{N}_{2}$. Dry DMF (100 mL) was added and the mixture refluxed overnight. After cooling down the solution, DMF was removed under vacuum and the resulting solid dissolved in EtOAc (100 mL). The solution was washed with brine $(4 \times 100 \mathrm{~mL})$ and the organic phase dried with $\mathrm{Na}_{2} \mathrm{SO}_{4}$, filtered and concentrated in vacuo. The recovered solid was purified by chromatography on silica gel using $\mathrm{CH}_{2} \mathrm{Cl}_{2}: \mathrm{MeOH}$ (96:4) as eluent, yielding $4.2 \mathrm{~g} \mathrm{(51 \% )} \mathrm{of} \mathrm{a}$ white solid.

${ }^{1} \mathrm{H}$ NMR $\left(400 \mathrm{MHz}, \mathrm{DMSO}-d_{6}\right) \delta 12.99(\mathrm{~s}, 1 \mathrm{H}), 7.86(\mathrm{~s}, 4 \mathrm{H}), 2.90-2.78(\mathrm{~m}, 2 \mathrm{H}), 1.89(\mathrm{td}, J=$ $11.4,9.9,3.1 \mathrm{~Hz}, 2 \mathrm{H}), 1.70-1.59(\mathrm{~m}, 2 \mathrm{H}), 1.55-1.36(\mathrm{~m}, 6 \mathrm{H})$.

\section{1-(4,5,6,7-tetrachloro-1,3-dioxoisoindolin-2-yl)cyclohexane-1-carboxylic acid (TCPTCC)}<smiles>CCCCC1(C(=O)O)C(=O)c2c(Cl)c(Cl)c(Cl)c(Cl)c2C1=O</smiles>

From modified literature procedure. ${ }^{4}$ In an open $100 \mathrm{~mL}$ round bottom flask tetrachloro phthalic anhydride $(4.0 \mathrm{~g}, 13.99 \mathrm{mmol}, 1.0$ equiv) and 1-aminocyclohexanecarboxylic acid $(2.0 \mathrm{~g}, 13.99 \mathrm{mmol}, 1.0$ equiv) were introduced with $4 \mathrm{~mL}$ of DMF and a stirring bar. This slurry was heated at $150^{\circ} \mathrm{C}$ and stirred for $1 \mathrm{~h}$ (open flask) until the mixture became slightly orange. The yellow-orange material was triturated three times with $40 \mathrm{~mL}$ of $\mathrm{CH}_{2} \mathrm{Cl}_{2}$ and filtered on a $\mathrm{P} 3$ sintered glass. The mother liquor was again concentrated, triturated with additional $40 \mathrm{~mL}$ of $\mathrm{CH}_{2} \mathrm{Cl}_{2}$ and filtrated. The yellow solid was recovered and dried in vacuum yielding $3.71 \mathrm{~g}(66 \%)$ of the desired product.

Yellow solid; Mp: $261^{\circ} \mathrm{C}$; Rf: $0.52\left(\mathrm{SiO}_{2}, \mathrm{CH}_{2} \mathrm{Cl}_{2}: \mathrm{MeOH}\right.$ 9:1); ${ }^{1} \mathbf{H}$ NMR (400 MHz, DMSO- $\left.d_{6}\right) \delta$ $13.15(\mathrm{~s}, 1 \mathrm{H}), 2.76(\mathrm{~d}, J=12.6 \mathrm{~Hz}, 2 \mathrm{H}), 2.00-1.82(\mathrm{~m}, 2 \mathrm{H}), 1.70-1.36(\mathrm{~m}, 6 \mathrm{H}) ;{ }^{13} \mathrm{C}$ NMR (101 MHz, DMSO-d6) $\delta 172.9(1 \mathrm{C}), 164.1$ (2C), 138.6 (2C), $128.1(2 \mathrm{C}), 127.4(2 \mathrm{C}), 65.7(1 \mathrm{C})$, $31.2\left(2 \mathrm{CH}_{2}\right), 24.5\left(2 \mathrm{CH}_{2}\right), 21.9\left(\mathrm{CH}_{2}\right)$; IR (neat) $\tilde{v} / \mathrm{cm}^{-1}: 2934,2859,2530,1780,1699,1456$, $1421,1363,1320,1289,1252,1218,1198,1146,1160,1106,1047,955,931,913,849,786$,

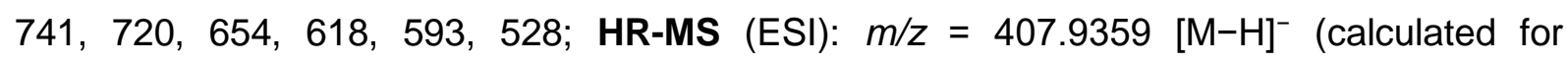
$\left.\mathrm{C}_{15} \mathrm{H}_{10} \mathrm{Cl}_{2} \mathrm{NO}_{4}, \mathrm{~m} / \mathrm{z}=407.9369\right)$. 


\subsection{Dirhodium complexes synthesis}

\section{$\mathrm{Rh}_{2}(\mathrm{PTCC})_{4}\left(\mathrm{EtOAC}_{2}-2 \mathrm{f}\right.$}

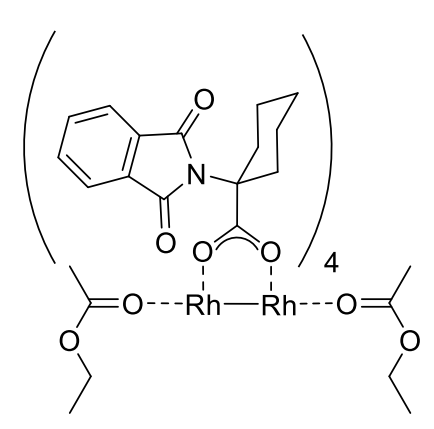

In a $100 \mathrm{~mL}$ flask rhodium acetate $(0.2 \mathrm{~g}, 452 \mu \mathrm{mol}, 1.0$ equiv) and 1-(1,3-dioxoisoindolin-2-yl)cyclohexane-1-carboxylic acid (PTCC) $(0.62 \mathrm{~g}, 2.26 \mathrm{mmol}, 5.0$ equiv) were introduced with $30 \mathrm{~mL}$ of dry chlorobenzene. To this flask, a small soxhlet containing $\mathrm{Na}_{2} \mathrm{CO}_{3}$, $\mathrm{CaO}$, quartz sand and $10 \mathrm{~mL}$ of dry chlorobenzene was installed with a reflux condenser on top. The system was refluxed at $160^{\circ} \mathrm{C}$ for $16 \mathrm{~h}$. After reaction time, the mixture was cooled to $25^{\circ} \mathrm{C}$ and concentrated. The green solid was purified by chromatography on silica gel with $\mathrm{CH}_{2} \mathrm{Cl}_{2}: \mathrm{MeOH}$ 95:5 as eluent. After concentration the green solid was crystalized using a biphasic system $\mathrm{CH}_{2} \mathrm{Cl}_{2}$ :EtAOc (1:1.5) yielding $450 \mathrm{mg}(\mathbf{6 7 \%})$ of complex $\mathbf{2 f} \mathbf{R h}_{\mathbf{2}}(\mathbf{P T C C})_{4}(\mathrm{EtOAc})_{2}$.

Green crystals; Mp: decomposition at $350{ }^{\circ} \mathrm{C}$; Rf: $0.54\left(\mathrm{SiO}_{2}, \mathrm{CH}_{2} \mathrm{Cl}_{2}: \mathrm{EtOAc} 95: 5\right) ;{ }^{1} \mathbf{H} \mathbf{N M R}$ $\left(500 \mathrm{MHz}, \mathrm{CD}_{2} \mathrm{Cl}_{2}\right) \delta 7.77-7.67(\mathrm{~m}, 16 \mathrm{H}), 4.07$ (q, $\left.J=7.1 \mathrm{~Hz}, 4 \mathrm{H}\right), 2.96(\mathrm{~d}, J=12.5 \mathrm{~Hz}, 8 \mathrm{H})$, $1.99(\mathrm{~s}, 6 \mathrm{H}), 1.75-1.67(\mathrm{~m}, 8 \mathrm{H}), 1.64-1.49(\mathrm{~m}, 12 \mathrm{H}), 1.34(\mathrm{~d}, J=8.8 \mathrm{~Hz}, 12 \mathrm{H}), 1.22(\mathrm{t}, J=$ $7.1 \mathrm{~Hz}, 6 \mathrm{H}) ;{ }^{13} \mathrm{C}$ NMR (126 MHz, $\left.\mathrm{CD}_{2} \mathrm{Cl}_{2}\right) \delta 192.9(4 \mathrm{C}), 171.6(2 \mathrm{C}), 169.3(8 \mathrm{C}), 134.1(8 \mathrm{C})$, $132.5(8 \mathrm{CH}), 123.1(8 \mathrm{CH}), 67.6(4 \mathrm{C}), 60.7\left(2 \mathrm{CH}_{2}\right), 32.7\left(8 \mathrm{CH}_{2}\right), 25.5\left(4 \mathrm{CH}_{2}\right), 23.0\left(8 \mathrm{CH}_{2}\right), 21.2$ $\left(2 \mathrm{CH}_{3}\right), 14.4\left(2 \mathrm{CH}_{3}\right) ;$ IR (neat) $\tilde{v} / \mathrm{cm}^{-1}: 2954,2841,1706,1603,1508,1454,1394,1317,1303$, 1244, 1177, 1141, 1077, 1036, 996, 957, 838, 811, 787, 750, 696, 638, 569; HR-MS (ESI): $\mathrm{m} / \mathrm{z}=1312.2107[\mathrm{M}+\mathrm{H}]^{+}$(calculated for $\mathrm{C}_{60} \mathrm{H}_{56} \mathrm{~N}_{4} \mathrm{O}_{16} \mathrm{Rh}_{2} \mathrm{~m} / \mathrm{z}=1312.2140$, without axial EtOAc); Elem. Anal.: Calculated for $\mathrm{C}_{68} \mathrm{H}_{72} \mathrm{~N}_{4} \mathrm{O}_{20} \mathrm{Rh}_{2}=\mathrm{C}: 55.52 \% ; \mathrm{H}: 4.93 \%, \mathrm{~N}: 3.81 \%$; Found $=\mathrm{C}: 55.18 \%, \mathrm{H}: 4.92 \%, \mathrm{~N}: 3.90 \%$. 


\section{$\mathrm{Rh}_{2}(\mathrm{TCPTCC})_{4}(\text { EtOAC })_{2}-2 \mathrm{~g}$}

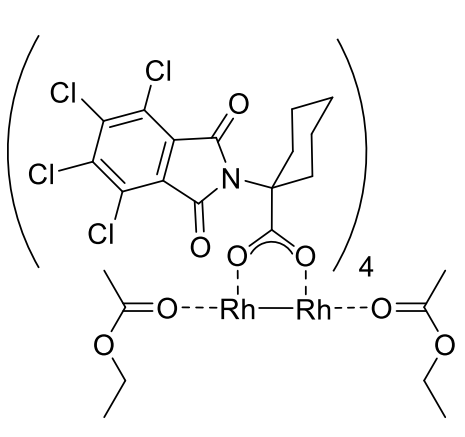

In a $100 \mathrm{~mL}$ flask, rhodium acetate $(0.15 \mathrm{~g}, 340 \mu \mathrm{mol}, 1.0$ equiv) and 1-(4,5,6,7-tetrachloro-1,3-dioxoisoindolin-2-yl)cyclohexane1-carboxylic acid (TCPTCC) (0.7 g, $1.7 \mathrm{mmol}, 5.0$ equiv) were introduced with $50 \mathrm{~mL}$ of dry chlorobenzene. To this flask a small soxhlet containing $\mathrm{Na}_{2} \mathrm{CO}_{3}, \mathrm{CaO}$, quartz sand and $10 \mathrm{~mL}$ of dry chlorobenzene was installed with a reflux condenser on top. The system was refluxed at $160^{\circ} \mathrm{C}$ for $16 \mathrm{~h}$. After reaction time, the mixture was cooled at $25^{\circ} \mathrm{C}$, diluted with $40 \mathrm{~mL}$ of EtOAc and washed with saturated $\mathrm{NaHCO}_{3}$ $(3 \times 10 \mathrm{~mL})$, water $(1 \times 10 \mathrm{~mL})$, brine $(1 \times 10 \mathrm{~mL})$ and dried over $\mathrm{Na}_{2} \mathrm{SO}_{4}$. The solution was concentrated until ca. $5 \mathrm{~mL}$ of solvent and the complexe is crystallize using a biphasic system chlorobenzene:EtOAc (1:3) yielding $430 \mathrm{mg}(\mathbf{5 7 \%})$ of complex $\mathbf{2 g} \mathbf{R h}_{\mathbf{2}}$ (TCPTCC) (EtOAC) $_{2}$.

Green crystals; Mp: decomposition at $350{ }^{\circ} \mathrm{C}$; Rf: $0.67\left(\mathrm{SiO}_{2}, \mathrm{CH}_{2} \mathrm{Cl}_{2}: \mathrm{EtOAc} 95: 5\right) ;{ }^{1} \mathbf{H}$ NMR (500 MHz, Chloroform-d) $\delta 4.12$ (q, $J=7.1 \mathrm{~Hz}, 4 \mathrm{H}$ ), 2.90 (d, $J=14.0 \mathrm{~Hz}, 8 \mathrm{H}), 2.04(\mathrm{~s}, 6 \mathrm{H})$, $1.83-1.73(\mathrm{~m}, 8 \mathrm{H}), 1.69-1.59(\mathrm{~m}, 8 \mathrm{H}), 1.56(\mathrm{~d}, J=7.6 \mathrm{~Hz}, 4 \mathrm{H}), 1.40-1.16(\mathrm{~m}, 18 \mathrm{H}) ;{ }^{13} \mathrm{C}$

NMR (126 MHz, Chloroform-d) $\delta 191.9$ (4C), 172.4 (2C), 164.2 (8C), 139.9 (8C), 129.3 (8C), $127.5(8 \mathrm{C}), 68.4(4 \mathrm{C}), 60.8\left(2 \mathrm{CH}_{2}\right), 32.3\left(8 \mathrm{CH}_{2}\right), 25.0\left(4 \mathrm{CH}_{2}\right), 22.7\left(8 \mathrm{CH}_{2}\right), 21.1\left(2 \mathrm{CH}_{3}\right), 14.3$ $\left(2 \mathrm{CH}_{3}\right)$; IR (neat) $\tilde{v} / \mathrm{cm}^{-1}: 2936,2855,1775,1721,1693,1603,1442,1393,1370,1312,1285$, 1263, 1201, 1149, 1090, 1041, 942, 910, 849, 808, 753, 737, 656, 610, 569, 541; HR-MS (ESI): Not determined due to difficult in ionization; Elem. Anal.: Calculated for $\mathrm{C}_{68} \mathrm{H}_{56} \mathrm{Cl}_{16} \mathrm{~N}_{4} \mathrm{O}_{20} \mathrm{Rh}_{2}=\mathrm{C}: 40.39 \%$; $: 2.79 \%, \mathrm{~N}: 2.77 \%$; Found = C: $40.21 \%, \mathrm{H}: 2.80 \%, \mathrm{~N}$ : $2.75 \%$. 


\section{Kinetics of diazo 1 decomposition $-0.1 \mathrm{~mol} \%$ of $\mathrm{Rh}_{2}(\mathrm{PTCC})_{4} \mathbf{2 g}$, $\mathrm{Rh}_{2}(\mathrm{TCPTCC})_{4} \mathbf{2 f}$}

Same protocol as in section 4 of the ESI with $0.1 \mathrm{~mol} \%$ of $\mathbf{2 g}, \mathbf{2} \mathbf{f}$

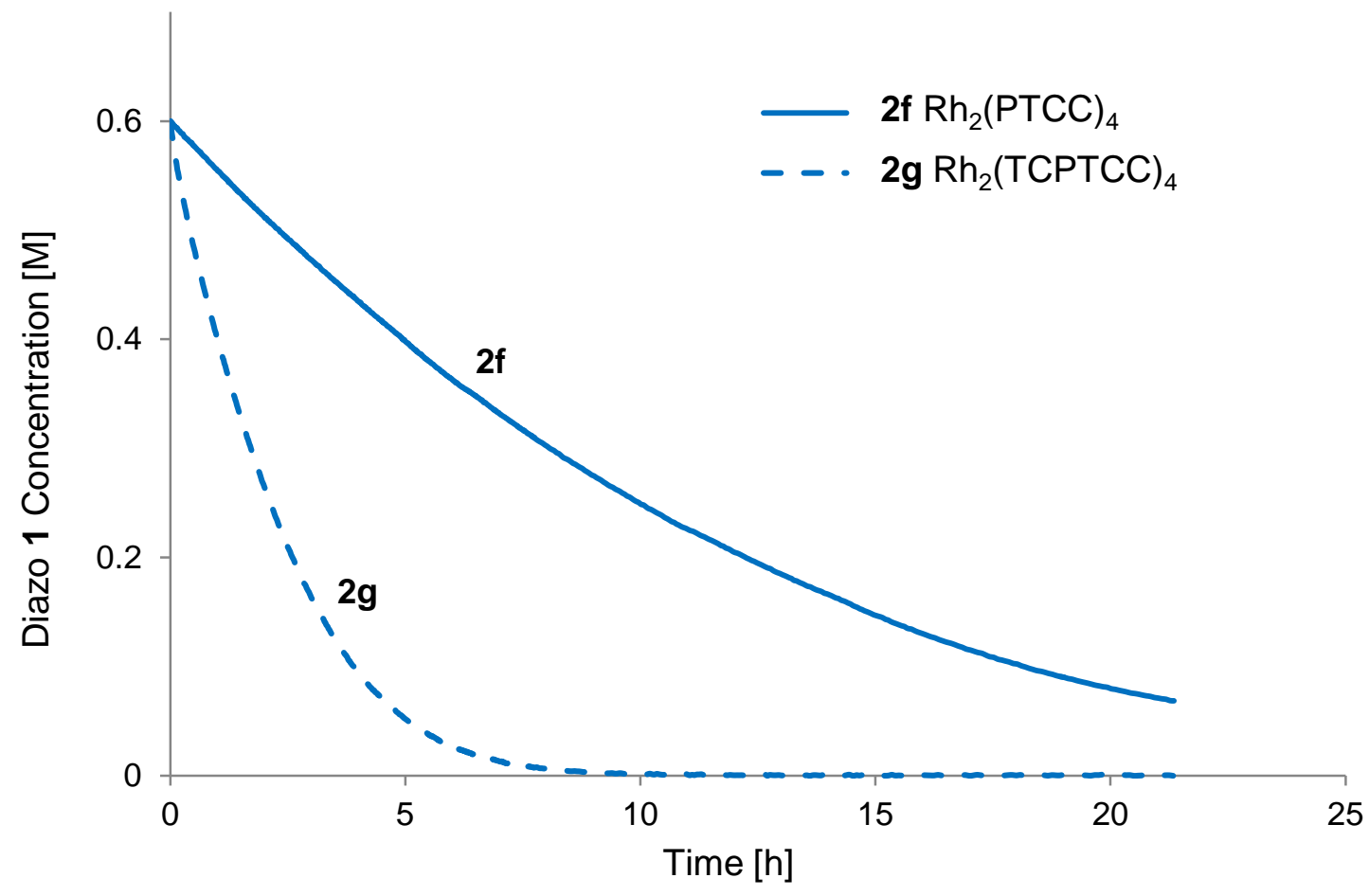

Figure S41 Diazo 1 concentration [M] evolution during reaction time [h] using $0.1 \mathrm{~mol} \%$ of different $\mathrm{Rh}_{2} \mathrm{~L}_{4}$ complexes (2f and $\mathbf{2 g}$ ). Trends from $2146 \mathrm{~cm}^{-1} \mathrm{IR}$ intensity, normalized at $\mathrm{t}_{0}=0.6 \mathrm{M}$ for diazo 1 . 


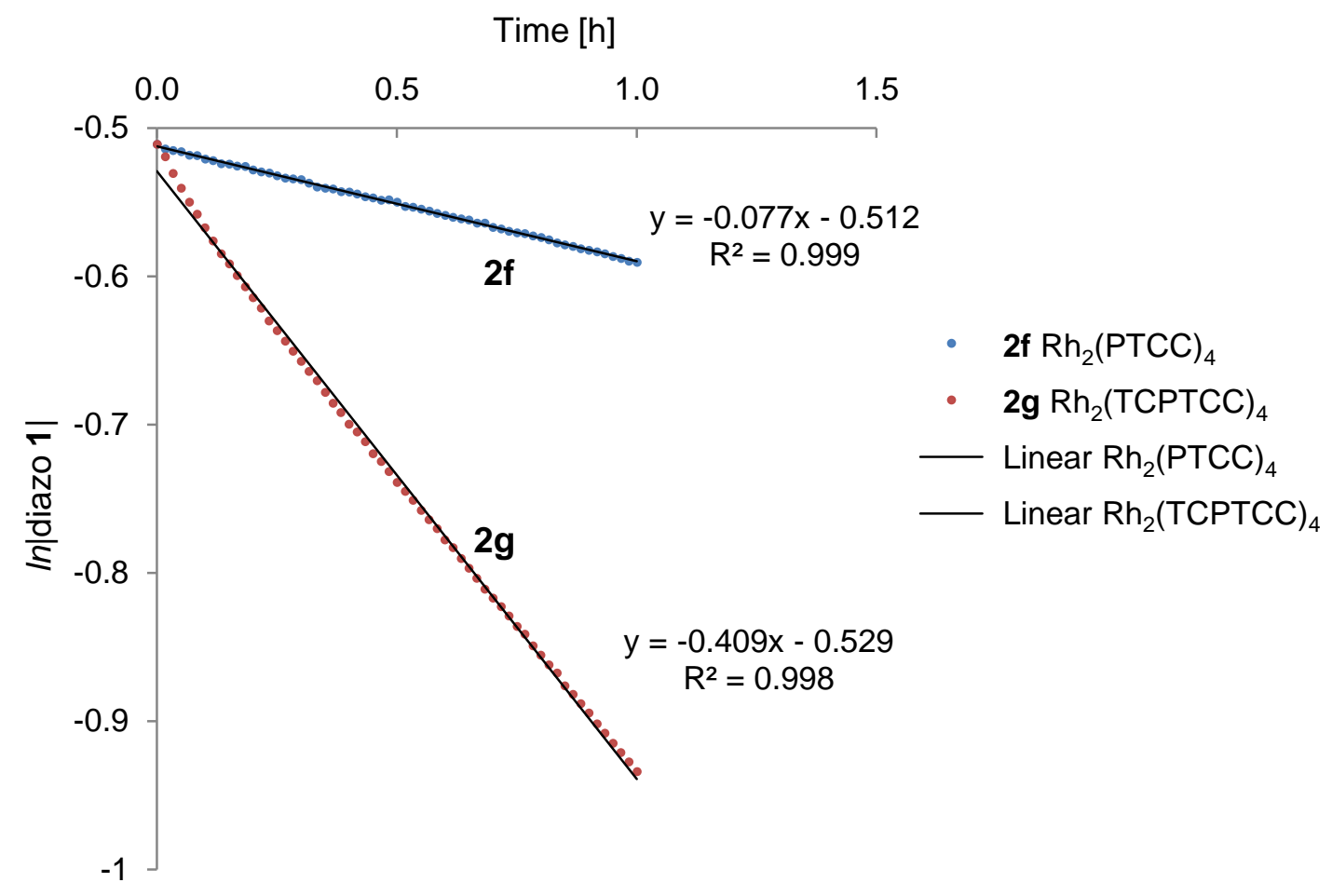

Figure S42 First order linearization of diazo 1 concentration and corresponding trend lines.

Experiments using $1.0 \mathrm{~mol} \%$ of $\mathrm{Rh}_{2} \mathrm{~L}_{4}$ (2f and $\mathbf{2 g}$ ).

Table S10 Pseudo-first order kinetic constants $\boldsymbol{k}_{1}$ for the decomposition of diazo 1 using $0.1 \mathrm{~mol} \%$ of $\mathrm{Rh}_{2} \mathrm{~L}_{4}(\mathbf{2 f}$ and $\mathbf{2 g}$ ). Yields and purities of isolated macrocycle 4.

\begin{tabular}{cccccc}
\hline Entry & \multicolumn{1}{c}{ Complex } & $\mathbf{k}_{\mathbf{1}}\left[\mathbf{h}^{-1}\right]$ & $R^{2}$ & Yield [\%] $^{\mathrm{a}}$ & Purity [\%] $^{\mathrm{b}}$ \\
\hline 1 & $\mathbf{2 f ~ R h}(\text { PTCC })_{4}$ & $\mathbf{0 . 0 8}$ & 0.999 & $78^{\mathrm{c}}$ & $98.8^{\mathrm{c}}$ \\
5 & $\mathbf{2 \mathrm { g } \mathrm { Rh } _ { 2 } ( \text { TCPTCC }}{ }_{4}$ & $\mathbf{0 . 4 1}$ & 0.998 & 81 & 98.8 \\
\hline
\end{tabular}

a Yield corrected by GC-FID purity. ${ }^{\mathrm{b}}$ Analyzed by GC-FID. ${ }^{\mathrm{c}}$ Yield and purity obtained in a separated reaction, after $48 \mathrm{~h}$. 


\section{200-mg, $1-\mathrm{g}$ and $20-\mathrm{g}$ scale reactions at $0.001 \mathrm{~mol} \%$ of catalysts}

\section{1 $200 \mathrm{mg}$-scale: $10 \mathrm{ml}$ microwave capped vials}

$\mathrm{Rh}_{2} \mathrm{~L}_{4}$ complex $\mathbf{2 d - 2 g}, 0.001$ mol\%, was introduced in a $5 \mathrm{~mL}$ microwave vial. ${ }^{5}$ 1.4-Dioxane ( $0.720 \mathrm{~mL}, 6.0$ equiv), $\mathrm{CHCl}_{3}(1.73 \mathrm{~mL})$ and diazo 1 ( $0.2 \mathrm{~g}, 1.41 \mu \mathrm{mol}, 1.0$ equiv) were added successively. The vial was capped and the reaction stirred at $60^{\circ} \mathrm{C}$. When diazo 1 was totally consumed (TLC monitoring) the pressure in the vial was released and the crude mixture was transferred into a round bottom flask. The reaction vessel was rinsed with $\mathrm{CH}_{2} \mathrm{Cl}_{2}(\times 3)$ and the combined solutions concentrated in vacuo. The recovered solid was dissolved in $1.0 \mathrm{~mL}$ of $\mathrm{CH}_{2} \mathrm{Cl}_{2}$, precipitated with $20 \mathrm{~mL}$ of pentane, filtered on a P3 sintered glass filter and washed with ether:pentane (1:9). The white solid recovered was dissolved in $\mathrm{CH}_{2} \mathrm{Cl}_{2}$, concentrated and dried in vacuo to yield macrocycle 4. In all experiments, the purity found by GC-FID analysis was between $97.7 \%$ and $99.5 \%$.

In some experiments, 1,4-dioxane was used both as reagent and solvent (no need for $\mathrm{CHCl}_{3}$ ). A total volume of $2.35 \mathrm{~mL}$ was introduced in the flask.

\subsection{1-g-scale: $25 \mathrm{ml}$ schlenk tube equipped with a reflux condenser}

$\mathrm{Rh}_{2} \mathrm{~L}_{4}$ complex $\mathbf{2 e}$ or $\mathbf{2 g}, 0.001 \mathrm{~mol} \%$, was introduced in a flame-dried $25 \mathrm{~mL}$ schlenk tube equipped with a reflux condenser and under $\mathrm{N}_{2}$ atmosphere. Error! Bookmark not defined. 1.4-Dioxane $3.60 \mathrm{~mL}, 42.2 \mathrm{mmol}, 6.0$ equiv), $\mathrm{CHCl}_{3}(8.1 \mathrm{~mL})$ and $1.0 \mathrm{~g}$ of diazo 1 (7.0 mmol, 1.0 equiv) were added successively and the solution stirred at $60^{\circ} \mathrm{C}$. When diazo 1 was totally consumed (TLC monitoring), the crude mixture was transferred into a round bottom flask. The reaction vessel was rinsed with $\mathrm{CH}_{2} \mathrm{Cl}_{2}(\times 3)$ and the combined solutions concentrated in vacuo. The recovered solid was dissolved in $6.0 \mathrm{~mL}$ of $\mathrm{CH}_{2} \mathrm{Cl}_{2}$, precipitated with $100 \mathrm{~mL}$ of pentane, filtered on a P3 sintered glass filter and washed with $100 \mathrm{ml}$ of ether:pentane (1:9). The white solid recovered was dissolved in $\mathrm{CH}_{2} \mathrm{Cl}_{2}$, concentrated and dried in vacuo to yield macrocycle 4. For all these experiment, the purity found by GC-FID analysis was between $97.0 \%$ and $98.2 \%$.

\subsection{0-g-scale: $500 \mathrm{ml}$ three neck flask equipped with a reflux condenser}

In a three neck $500 \mathrm{~mL}$ flask equipped with a reflux condenser and an dropping funnel, 0.001 mol\% of catalyst $\mathbf{2 d - 2 g}$ were introduced with $235 \mathrm{~mL}$ of 1.4 -dioxane (2.74 mol, 19.6 equiv). 
Diazo 1 (20 g) was slowly added to the solution during 5 minutes, at $25^{\circ} \mathrm{C}$, via the dropping funnel and the resulting yellow solution stirred at $60^{\circ} \mathrm{C}$. When diazo 1 was totally consumed (TLC monitoring), the crude mixture was transferred into a $500 \mathrm{~mL}$ round bottom flask. The reaction vessel was rinsed with $\mathrm{CH}_{2} \mathrm{Cl}_{2}(x 3)$ and the combined solutions concentrated in vacuo. The recovered solid was dissolved in $200 \mathrm{~mL}$ of $\mathrm{CH}_{2} \mathrm{Cl}_{2}$, transferred into a $2.0 \mathrm{~L}$ Erlenmeyer and precipitated with $1.0 \mathrm{~L}$ of pentane. The precipitate was stirred for $2 \mathrm{~h}$, filtered on a P3 sintered glass filter and washed with $1.0 \mathrm{~L}$ of a solution of pentane:ether 9:1. The white solid recovered was dissolved in $\mathrm{CH}_{2} \mathrm{Cl}_{2}$, concentrated and dried in vacuo to yield macrocycle 4 .

With catalysts $\mathrm{Rh}_{2}(S-P T T L)_{4} \mathbf{2 d}$ and $\mathrm{Rh}_{2}(S-T C P T T L)_{4} \mathbf{2 e}$, side products could be noticed in the ${ }^{1} \mathrm{H}$-NMR spectra of isolated macrocycles 4 (Figure S43). Further purification was required. The white solid was dissolved in $\mathrm{CH}_{2} \mathrm{Cl}_{2}$ and passed through a pack of neutral aluminum oxide (Brockmann I) and eluted with a solution of 1:1 EtOAc: $\mathrm{CH}_{2} \mathrm{Cl}_{2}$. After concentration of the filtrate, ${ }^{1} \mathrm{H}$-NMR spectroscopic analysis indicated that the impurities were still present. The product was then dissolved in $200 \mathrm{~mL}$ of hot THF and allowed to gently crystalize overnight. After filtration, product $\mathbf{4}$ was recovered without impurities. 


\section{$9.420-g$ scale reactions: ${ }^{1} \mathrm{H}$ NMR analysis of the initial precipitates}

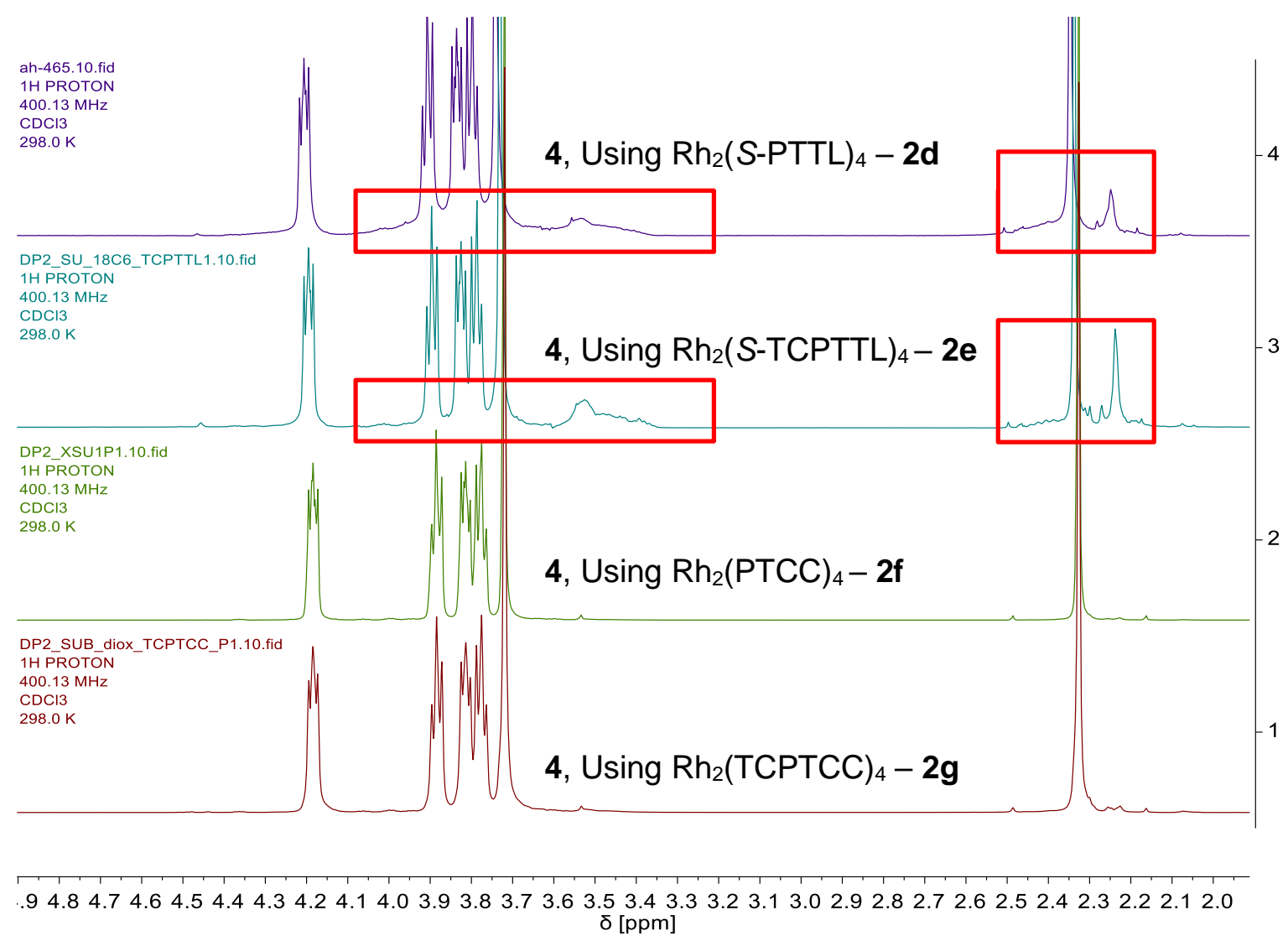

Figure S43 Comparison of ${ }^{1} \mathrm{H}-\mathrm{NMR}$ spectra of macrocycle $\mathbf{4}$ after reaction using dirhodium complexes $\mathbf{2 d}, \mathbf{2 e}, \mathbf{2} \mathbf{f}$ and $\mathbf{2 g}$. Impurities highlighted in red. 


\section{Reaction scope with catalyst $2 \mathrm{~g}$ at $0.01 \mathrm{~mol} \%$ - Diazo reagent screening}

In a flame-dried $25 \mathrm{~mL}$ schlenk tube equipped with a reflux condenser, $0.01 \mathrm{~mol} \%$ of rhodium complex $\mathrm{Rh}_{2}(\text { TCPTCC) })_{4} \mathbf{2 g}$ was introduced with 1.4-dioxane $(11.7 \mathrm{~mL})$ under an $\mathrm{N}_{2}$ atmosphere. To this solution, $7 \mathrm{mmol}$ of the desired diazo reagent was added and the mixture was stirred at $60^{\circ} \mathrm{C}$. When diazo of type 1 was totally consumed (15 h, TLC monitoring) the crude mixture was transferred into a round bottom flask. The reaction vessel was rinsed with $\mathrm{CH}_{2} \mathrm{Cl}_{2}(x 3)$ and the combined solutions concentrated in vacuo. Purification steps are detailed below depending on the macrocyclic product formed.

Purification method A: After concentration, the white precipitate was dissolved in a minimum amount of $\mathrm{CH}_{2} \mathrm{Cl}_{2}$ (ca. 5-7 mL) and then pentane $(100 \mathrm{~mL}$ ) was added to the solution. The resulting precipitate was filtered on a P3 sintered glass filter and washed with a solution of pentane:ether 9:1 (100 $\mathrm{mL})$. The solid was recovered with $\mathrm{CH}_{2} \mathrm{Cl}_{2}$, concentrated and dried in high vacuum to yield the corresponding macrocycle.

Purification method B: After concentration the white precipitate was dissolved in $\mathrm{CH}_{2} \mathrm{Cl}_{2}(10$ $\mathrm{ml}$ ) and into the flask $1 \mathrm{~g}$ of neutral alumina (Brockmann I) were added. The slurry was concentrated in vacuo and the resulting solid laid down on a pad of neutral alumina and eluted with EtOAc: $\mathrm{CH}_{2} \mathrm{Cl}_{2}$ 1:1 (500 mL). The filtrate was concentrated and the residual solid was dissolved in a minimum of $\mathrm{CH}_{2} \mathrm{Cl}_{2}$ (ca. 5-7 mL). To this solution, $100 \mathrm{ml}$ of pentane were added and the resulting precipitate was filtered on a P3 sintered glass filter and washed with a solution of pentane:ether 9:1 (100 mL). The recovered solid was dried in vacuo to yield the corresponding macrocycle.

Purification method C: The product was purified by column chromatography on neutral alumina (Brockmann I). The product was introduced in the column by a solid deposit $\left(\mathrm{CH}_{2} \mathrm{Cl}_{2}\right.$ and neutral alumina, see purification method B). EtOAc:pentane $(1: 9,3: 7,1: 1)$ and then EtOAc: $\mathrm{CH}_{2} \mathrm{Cl}_{2}$ (1:1) were used as eluting solvents to yield the corresponding macrocycle. 
<smiles>CCOC(=O)C1=C(C)OCCOCCO/C(C(=O)OCC)=C(/C)OCCOCCO1</smiles>

5

$6(\mathrm{R}=i-\mathrm{Bu})$; purification method $\mathrm{B}, 40 \%$, white solid. Mp: $86.4{ }^{\circ} \mathrm{C}-88.7^{\circ} \mathrm{C} . \mathbf{R f}=0.55,\left(\mathrm{SiO}_{2} \mathrm{CH}_{2} \mathrm{Cl}_{2}: \mathrm{MeOH}\right.$ 9:1). ${ }^{1} \mathrm{H}$ NMR $\left(500 \mathrm{MHz}, \mathrm{CDCl}_{3}\right) \delta / p p m=0.96(\mathrm{~d}, 12 \mathrm{H}$, $\mathrm{J}=6.7 \mathrm{~Hz}), 1.98$ (hept, $2 \mathrm{H}, \mathrm{J}=6.7 \mathrm{~Hz}), 2.34(\mathrm{~s}, 6 \mathrm{H})$, 6 3.79 - $3.81(\mathrm{~m}, 4 \mathrm{H}), 3.83$ - $3.85(\mathrm{~m}, 4 \mathrm{H}), 3.91-3.93(\mathrm{~m}$, 8H), $4.19-4.21(\mathrm{~m}, 4 \mathrm{H}) .{ }^{13} \mathrm{C}$ NMR $\left(126 \mathrm{MHz}, \mathrm{CDCl}_{3}\right) \delta / \mathrm{ppm}=15.4,19.4,28.0,68.9,70.2,70.6$, 70.7, 72.3, 130.1, 158.35, 166.2. IR (neat): $\tilde{\text { ṽ }} \mathrm{cm}^{-1}$ 2952, 2894, 1701, 1615, 1462, 1378, 1309, $1269,1237,1162,1129,1085,1030,983,929,896,870,833,813,776,690,632,577$. HRESI: $\mathrm{m} / \mathrm{z}=\left[\mathrm{M}+\mathrm{NH}_{4}\right]^{+} 506.2945$ (calculated for $\mathrm{C}_{24} \mathrm{H}_{44} \mathrm{O}_{10} \mathrm{~N} \mathrm{~m} / \mathrm{z}=506.2960$ ).<smiles>C/C(OCCOCCOC(C)OCc1ccccc1)=C(\OCCOCCOCc1ccccc1)C(=O)OCc1ccccc1</smiles>

$7(\mathrm{R}=\mathrm{Bn})$; purification method $\mathrm{B}, \mathbf{5 5 \%}$, white solid. Mp: $99.7^{\circ} \mathrm{C}-100.6^{\circ} \mathrm{C} . \mathbf{R f}=0.58\left(\mathrm{SiO}_{2}, \mathrm{CH}_{2} \mathrm{Cl}_{2}: \mathrm{MeOH} 9: 1\right)$. ${ }^{1} \mathrm{H}$ NMR $\left(500 \mathrm{MHz}, \mathrm{CDCl}_{3}\right) \delta / \mathrm{ppm}=2.34(\mathrm{~s}, 6 \mathrm{H}), 3.75-$ $3.77(\mathrm{~m}, 4 \mathrm{H}), 3.80-3.81(\mathrm{~m}, 4 \mathrm{H}), 3.89-3.91(\mathrm{~m}, 4 \mathrm{H})$, 4.18 - $4.20(\mathrm{~m}, 4 \mathrm{H}), 5.20(\mathrm{~s}, 4 \mathrm{H}), 7.28-7.38(\mathrm{~m}, 10 \mathrm{H}) \cdot{ }^{13} \mathrm{C}$ NMR $\left(126 \mathrm{MHz} \mathrm{CDCl}_{3}\right) \delta / \mathrm{ppm}=15.5,66.0,68.6,70.1,70.7,72.3,128.0,128.1,128.6,129.8$, 136.6, 158.9, 165.9. IR (neat): $\tilde{\mathrm{v}} / \mathrm{cm}^{-1} 3060,2941,2882,1692,1614,1500,1453,1436,1268$, 1233, 1162, 1099, 1030, 981, 934, 903, 871, 814, 773, 728, 694, 630, 575. HR-ESI: m/z = $[\mathrm{M}+\mathrm{Na}]^{+} 579.2189$ (calculated for $\mathrm{C}_{30} \mathrm{H}_{36} \mathrm{O}_{10} \mathrm{Na} \mathrm{m} / \mathrm{z}=579.2201$ ).<smiles></smiles>

$8\left(\mathrm{R}=\left(\mathrm{CH}_{2}\right)_{2} \mathrm{Ph}\right)$; purification method $\mathrm{A}, 78 \%$, white solid. Spectral and physical data are in agreement with previously reported literature. ${ }^{2}$ 
<smiles>C/C1=C(\C(=O)OCC(Cl)(Cl)Cl)OCCOCCO/C(C(=O)OCC(Cl)(Cl)Cl)=C(/C)OCCOCCO1</smiles>

9

$9\left(\mathrm{R}=\mathrm{CH}_{2} \mathrm{CCl}_{3}\right)$, purification method $\mathrm{C}, 39 \%$, white solid. Mp: $91.3{ }^{\circ} \mathrm{C}-92.7{ }^{\circ} \mathrm{C}$. $\mathbf{R f}=0.65\left(\mathrm{SiO}_{2}\right.$, $\mathrm{CH}_{2} \mathrm{Cl}_{2}: \mathrm{MeOH}$ 9:1). ${ }^{1} \mathrm{H}$ NMR (500 MHz, $\left.\mathrm{CDCl}_{3}\right) \delta / p p m$ $=2.40(\mathrm{~s}, 6 \mathrm{H}), 3.823 .84(\mathrm{~m}, 4 \mathrm{H}), 3.86-3.88(\mathrm{~m}, 4 \mathrm{H})$, $3.98-4.00(\mathrm{~m}, 4 \mathrm{H}), 4.24-4.25(\mathrm{~m}, 4 \mathrm{H}), 4.81(\mathrm{~s}$, 4H). ${ }^{13} \mathrm{C}$ NMR $\left(126 \mathrm{MHz}, \mathrm{CDCl}_{3}\right) \delta / p p m=15.4,68.8,70.0,70.7,72.7,74.0,95.5,128.5,161.2$, 164.4. IR (neat): $\tilde{\text { V}} / \mathrm{cm}^{-1} 2941,1758,1714,1614,1438,1380,1366,1267,1240,1157,1091$, 1059, 975, 940, 862, 822, 783, 766, 710, 629, 570. HR-ESI: m/z = [M+Na $]^{+} 658.9552$ (calculated for $\mathrm{C}_{20} \mathrm{H}_{26} \mathrm{Cl}_{6} \mathrm{O}_{10} \mathrm{Na} \mathrm{m} / \mathrm{z}=658.9549$ ).

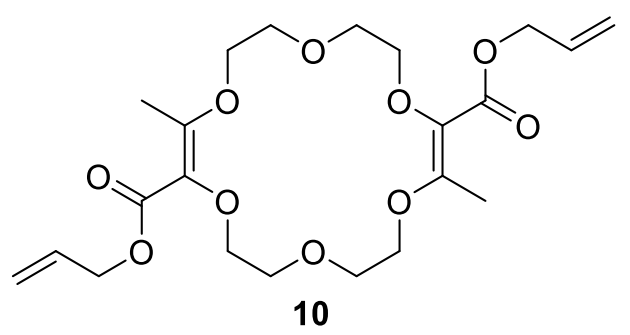

$10(\mathrm{R}=$ allyl), purification method $\mathrm{C}, 63 \%$, white solid. Spectral and physical data are in agreement with previously reported literature. ${ }^{2}$

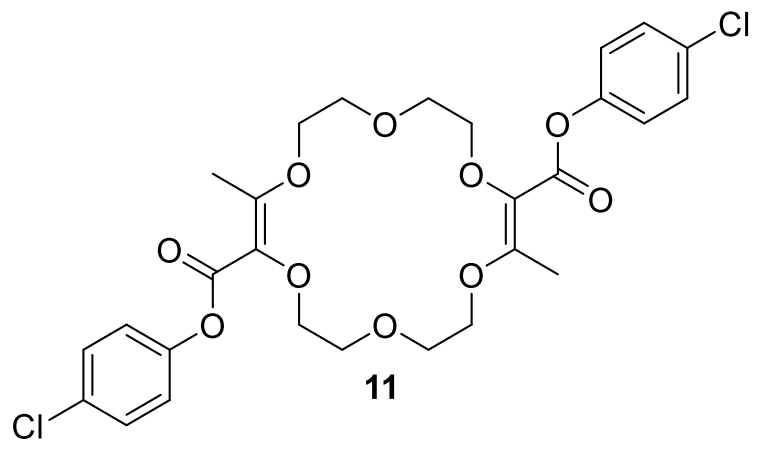

$11\left(\mathrm{R}=p-\mathrm{Cl}-\mathrm{C}_{6} \mathrm{H}_{4}\right)$, purification method $\mathrm{C}, 15 \%$, white solid. Mp: $148.6^{\circ} \mathrm{C}-150.1^{\circ} \mathrm{C}$. $\mathbf{R f}=0.65$ $\left(\mathrm{SiO}_{2}, \mathrm{CH}_{2} \mathrm{Cl}_{2}: \mathrm{MeOH}\right.$ 9:1). ${ }^{1} \mathrm{H}$ NMR $(500 \mathrm{MHz}$, $\left.\mathrm{CDCl}_{3}\right) \delta / \mathrm{ppm}=2.41(\mathrm{~s}, 6 \mathrm{H}), 3.87-3.91(\mathrm{~m}$, $8 \mathrm{H}), 4.04-4.06(\mathrm{~m}, 4 \mathrm{H}), 4.27-4.28(\mathrm{~m}, 4 \mathrm{H})$, $7.04(\mathrm{~m}, 4 \mathrm{H}), 4.33-7.36,4 \mathrm{H}) .{ }^{13} \mathrm{C}$ NMR $(126$ $\left.\mathrm{MHz}, \mathrm{CDCl}_{3}\right) \delta / p p m=15.3,68.7,70.0,70.8$, 72.6, 123.5, 128.8, 129.5, 131.1, 149.5, 161.2, 164.7. IR (neat): $\tilde{\mathrm{v}} / \mathrm{cm}^{-1} 2941,2886,1718,1610$, 1489, 1434, 1380, 1271, 1236, 1201, 1154, 1127, 1094, 1059, 1034, 1013, 982, 936, 892, 856, 812, 792, 763, 617. HR-ESI: $\mathrm{m} / \mathrm{z}=[\mathrm{M}+\mathrm{Na}]^{+} 619.1103$ (calculated for $\mathrm{C}_{28} \mathrm{H}_{30} \mathrm{Cl}_{2} \mathrm{O}_{10} \mathrm{Na} \mathrm{m} / \mathrm{z}=$ 619.1103).<smiles>CCC1=C(CC)OCCOCCOC(C(=O)OC)=C(CC)OCCOCCO1</smiles>

12

$12\left(R=\right.$ Me, $\left.R^{\prime}=E t\right)$, purification method A, 23\%, white solid. Mp: $124.0^{\circ} \mathrm{C}-124.4^{\circ} \mathrm{C} . \mathbf{R f}=0.53\left(\mathrm{SiO}_{2}\right.$, pentane:EtOAc $\left.1: 1\right) .{ }^{1} \mathbf{H}$ NMR $\left(500 \mathrm{MHz}, \mathrm{CDCl}_{3}\right) \delta / \mathrm{ppm}=1.11(\mathrm{t}, J=7.4 \mathrm{~Hz}, 6 \mathrm{H}), 2.67$ (q, $J=7.4$ $\mathrm{Hz}, 4 \mathrm{H}), 3.75$ - $3.79(\mathrm{~m}, 14 \mathrm{H}), 3.89$ - $3.91(\mathrm{~m}, 4 \mathrm{H}), 4.35$ - $4.37(\mathrm{~m}$, $4 \mathrm{H}) \cdot{ }^{13} \mathrm{C}$ NMR $\left(126 \mathrm{MHz}, \mathrm{CDCl}_{3}\right) \delta / \mathrm{ppm}=12.0,23.6,51.5,70.3$, 70.3, 70.4, 72.2, 129.6, 163.7, 166.1. IR (neat): $\tilde{\text { ṽ }} \mathrm{cm}^{-1}$ 2952, 1701, 1614, 1436, 1328, 1280 , 
1229, 1186, 1156, 1106, 1085, 1056, 1018, 948, 920, 884, 814, 776, 709, 615. HR-ESI: m/z = $[\mathrm{M}+\mathrm{Na}]^{+} 455.1888$ (calculated for $\mathrm{C}_{20} \mathrm{H}_{32} \mathrm{O}_{10} \mathrm{Na} \mathrm{m} / \mathrm{z}=455.1888$ ).<smiles>CCCC1=C(C(=O)OC)OCCOCCOC(CCC)OCCOCCO1</smiles>

13

$13\left(\mathrm{R}=\mathrm{Me}, \mathrm{R}^{\prime}=n-\operatorname{Pr}\right)$, purification method $\mathrm{A}, \mathbf{3 4 \%}$, white solid. Mp: $82.7^{\circ} \mathrm{C}-84.4^{\circ} \mathrm{C} . \mathbf{R f}=0.23\left(\mathrm{SiO}_{2}\right.$, pentane:EtOAc $\left.1: 1\right) .{ }^{1} \mathbf{H}$ NMR $\left(500 \mathrm{MHz}, \mathrm{CDCl}_{3}\right) \delta / \mathrm{ppm}=0.94(\mathrm{t}, J=7.4 \mathrm{~Hz}, 6 \mathrm{H}), 1.50-$ $1.58(\mathrm{~m}, 4 \mathrm{H}), 2.61$ - $2.64(\mathrm{~m}, 4 \mathrm{H}), 3.74$ - $3.76(\mathrm{~m}, 14 \mathrm{H}), 3.88$ $3.90(\mathrm{~m}, 4 \mathrm{H}), 4.34-4.36(\mathrm{~m}, 4 \mathrm{H}) .{ }^{13} \mathrm{C}$ NMR $\left(126 \mathrm{MHz}, \mathrm{CDCl}_{3}\right)$ $\delta / p p m=14.0,21.1,32.1,51.6,70.4,70.4,70.5,72.3,130.3,162.6,166.3$. IR (neat): $\tilde{v} / \mathrm{cm}^{-1}$ 2945, 1706, 1601, 1488, 1457, 1432, 1373, 1266, 1224, 1187, 1134, 1096, 1058, 997, 930, 899, 880, 854, 776, 812. HR-ESI: $\mathrm{m} / \mathrm{z}=[\mathrm{M}+\mathrm{Na}]^{+} 483.2195$ (calculated for $\mathrm{C}_{22} \mathrm{H}_{36} \mathrm{O}_{10} \mathrm{Na} \mathrm{m} / \mathrm{z}=$ 483.2201). 


\section{Synthesis of the tetrahydropyran precursor to macrocycle 16}

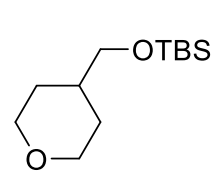

A modified literature procedure was used. $^{6}$ In a two neck $500 \mathrm{~mL}$ flask, imidazole (11.25 g, $165 \mathrm{mmol}, 2.4$ equiv) followed by TBSCl (12.46 g, $82 \mathrm{mmol}$, 1.2 equiv), were added to a solution containing (tetrahydro-2H-pyran-4yl)methanol ${ }^{7}\left(8.0 \mathrm{~g}, 68.8 \mathrm{mmol}, 1.0\right.$ equiv) in $150 \mathrm{~mL}$ of dry $\mathrm{CH}_{2} \mathrm{Cl}_{2}$. After $5 \mathrm{~h}$, the reaction was completed (TLC monitoring). The solution, containing a white suspension, was diluted with 100 $\mathrm{mL}$ of $\mathrm{CH}_{2} \mathrm{Cl}_{2}$ and washed with $\mathrm{NaHCO}_{3}(3 \times 100 \mathrm{~mL}$ ). The aqueous phase was extracted with additional $\mathrm{CH}_{2} \mathrm{Cl}_{2}(3 \times 100 \mathrm{~mL})$, then the collected organic phases were washed with aqueous saturated $\mathrm{NH}_{4} \mathrm{Cl}$, dried over $\mathrm{Na}_{2} \mathrm{SO}_{4}$, filtrated and concentrated. The recovered colorless oil was purified by chromatography with silica gel using pentane:ether (95:5) as eluent yielding $12.36 \mathrm{~g}(\mathbf{7 8 \%})$ of product tert-butyldimethyl((tetrahydro-2H-pyran-4-yl)methoxy)silane.

Colorless oil; 78\%; Rf: 0.6 (pentane:EtOAc 95:5; ${ }^{1} \mathbf{H}$ NMR $\left(400 \mathrm{MHz}, \mathrm{CDCl}_{3}\right) \delta 3.93$ (dd, $\mathrm{J}=$ 11.6, $4.7 \mathrm{~Hz}, 2 \mathrm{H}), 3.40(\mathrm{~d}, J=6.3 \mathrm{~Hz}, 2 \mathrm{H}), 3.34(\mathrm{td}, J=11.8,2.1 \mathrm{~Hz}, 2 \mathrm{H}), 1.74-1.61(\mathrm{~m}, 1 \mathrm{H})$, 1.57 (ddd, $J=13.1,4.0,1.9 \mathrm{~Hz}, 2 \mathrm{H}$ ), 1.25 (dtd, $J=13.3,11.9,4.6 \mathrm{~Hz}, 2 \mathrm{H}$ ), 0.85 (s, 9H), 0.00 $(\mathrm{s}, 6 \mathrm{H}) ;{ }^{13} \mathrm{C}$ NMR $\left(101 \mathrm{MHz}, \mathrm{CDCl}_{3}\right) \delta 68.0\left(1 \mathrm{CH}_{2}\right), 67.8\left(2 \mathrm{CH}_{2}\right), 37.8\left(1 \mathrm{CH}_{2}\right), 29.6\left(2 \mathrm{CH}_{2}\right)$, $25.3\left(3 \mathrm{CH}_{3}\right), 18.3(1 \mathrm{C}),-5.4\left(2 \mathrm{CH}_{3}\right)$; IR (neat) $\tilde{\mathbf{v}} / \mathbf{c m}^{-1}: 2929,2854,1467,1386,1360,1253$, 1147, 1092, 1073, 1032, 1009, 986, 938, 908, 835, 773, 666, 606, 574, 535; HR-MS (ESI): m/z $=231.1767[\mathrm{M}+\mathrm{H}]^{+}$(calculated for $\left.\mathrm{C}_{12} \mathrm{H}_{27} \mathrm{O}_{2} \mathrm{Si} \mathrm{m} / \mathrm{z}=231.1775\right)$. 


\section{Reaction scope with catalyst $2 \mathrm{~g}$ at $0.01 \mathrm{~mol} \%$ - Substituted THP substrates}

In a $25 \mathrm{~mL}$ round bottom flask equipped with a reflux condenser, $0.01 \mathrm{~mol} \%$ of $R \mathrm{~h}_{2}(\mathrm{TCPTCC})_{4}$ $2 \mathrm{~g}$ (1.54 mg, 0.0001 equiv) was introduced and dissolved in $6 \mathrm{~mL}$ of $\mathrm{CHCl}_{3}$. The desired THP substrate (6.0 equiv) was introduced, and diazo 1 (1.0 g, $7.04 \mathrm{mmol}, 1.0$ equiv) was then added. The solution was stirred for $20 \mathrm{~h}$ at $40^{\circ} \mathrm{C}$. After total consumption of diazo 1 (TLC monitoring), the crude mixture was transferred into a round bottom flask. The reaction vessel was rinsed with $\mathrm{CH}_{2} \mathrm{Cl}_{2}(\mathrm{x} 3)$. The combined solutions were then concentrated in vacuo and the resulting residue purified by chromatography.

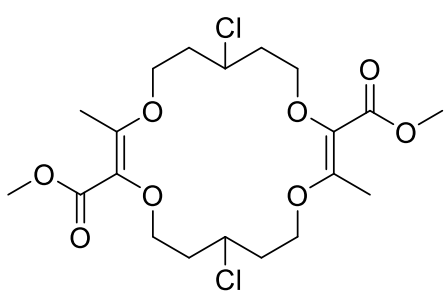

14; Neutral Alumina (Brockmann I), EtOAc:pentane 1:9 to 3:7; 67\%; White solid; ${ }^{1} \mathrm{H}$ NMR $\left(400 \mathrm{MHz}, \mathrm{CD}_{2} \mathrm{Cl}_{2}\right) \delta 4.64-4.50(\mathrm{~m}$, $2 \mathrm{H}), 4.35-4.24(\mathrm{~m}, 2 \mathrm{H}), 4.23-4.12(\mathrm{~m}, 2 \mathrm{H}), 3.92(\mathrm{td}, J=9.4$, $3.3 \mathrm{~Hz}, 1 \mathrm{H}), 3.85(\mathrm{dd}, J=6.7,4.2 \mathrm{~Hz}, 2 \mathrm{H}), 3.83-3.77(\mathrm{~m}, 1 \mathrm{H})$, $3.75(\mathrm{~s}, 6 \mathrm{H}), 2.41(\mathrm{~d}, J=2.7 \mathrm{~Hz}, 6 \mathrm{H}), 2.32-2.14(\mathrm{~m}, 4 \mathrm{H}), 2.11$ - $1.91(\mathrm{~m}, 4 \mathrm{H}) ;{ }^{13} \mathrm{C}$ NMR (101 MHz, $\left.\mathrm{CD}_{2} \mathrm{Cl}_{2}\right) \delta 166.1$ and $166.1(2 \mathrm{C}), 157.8$ and $157.7(2 \mathrm{C})$, 130.1 and $129.7(2 \mathrm{C}), 69.2$ and $69.0\left(2 \mathrm{CH}_{2}\right), 64.08$ and $64.06\left(2 \mathrm{CH}_{2}\right), 57.6$ and $57.4\left(2 \mathrm{CH}_{2}\right)$, $51.1(2 \mathrm{CH}), 39.3$ and $39.0\left(2 \mathrm{CH}_{2}\right), 38.5$ and $38.3\left(2 \mathrm{CH}_{2}\right), 13.7$ and $13.6\left(2 \mathrm{CH}_{3}\right)$. Diastereomeric ratio $(d r)$ 1.0:0.6. Spectral and physical data are in agreement with previously reported literature. ${ }^{8}$<smiles>COC(=O)CC(CCOC(C)=C(OCCC(CCOC(C)=C(C(=O)OC)C(=O)OC)C(=O)OC)C(=O)OC)C(=O)OC</smiles>

15, Neutral Alumina (Brockmann I), EtOAc:pentane 1:9 to 1:1; 52\%. Colorless oil. ' ${ }^{1} \mathrm{H}$ NMR $\left(400 \mathrm{MHz}, \mathrm{CD}_{2} \mathrm{Cl}_{2}\right) \delta 4.03-3.92(\mathrm{~m}$, $2 \mathrm{H}), 3.90-3.81(\mathrm{~m}, 2 \mathrm{H}), 3.68-3.54(\mathrm{~m}, 4 \mathrm{H}, 2$ singlets, $12 \mathrm{H})$, $2.94-2.84(\mathrm{~m}, 2 \mathrm{H}), 2.23(\mathrm{~d}, J=4.1 \mathrm{~Hz}, 6 \mathrm{H}), 1.99-1.86(\mathrm{~m}, 6 \mathrm{H})$, $1.84-1.70(\mathrm{~m}, 2 \mathrm{H}) .{ }^{13} \mathrm{C}$ NMR $\left(101 \mathrm{MHz}, \mathrm{CD}_{2} \mathrm{Cl}_{2}\right) \delta 176.2$ and $176.2(2 \mathrm{C}), 166.6(2 \mathrm{C}), 158.3$ and $158.2(2 \mathrm{C}), 130.1$ and 129.8 (2C), 70.5 and $70.4\left(2 \mathrm{CH}_{2}\right), 65.8$ and $65.6\left(2 \mathrm{CH}_{2}\right), 51.84$ and $51.81\left(2 \mathrm{CH}_{3}\right), 51.5\left(2 \mathrm{CH}_{3}\right), 39.3$ and $39.2\left(2 \mathrm{CH}_{2}\right), 32.7$ and $32.2\left(2 \mathrm{CH}_{2}\right), 32.6$ and $32.4(2 \mathrm{CH}), 14.3$ and $14.3\left(2 \mathrm{CH}_{3}\right)$; Diastereomeric ratio $(d r)$ 1.0:0.8. Spectral and physical data are in agreement with previously reported literature. ${ }^{8}$ 


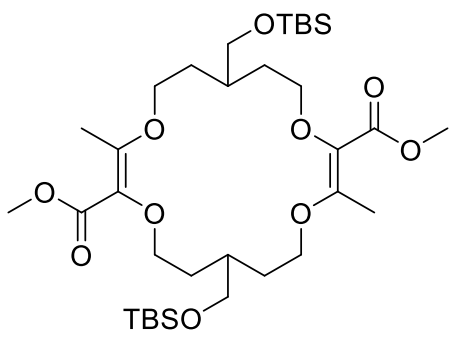

16; Neutral Alumina (Brockmann I), EtOAc:pentane 5:95 to 2:8; 62\%; Turbid oil; Rf: 0.65 (EtOAc:pentane 2:8); ${ }^{1} \mathbf{H}$ NMR (400 $\left.\mathrm{MHz}, \mathrm{CD}_{2} \mathrm{Cl}_{2}\right) \delta 4.22-4.01(\mathrm{~m}, 4 \mathrm{H}), 3.85-3.55(\mathrm{~m}, 14 \mathrm{H}), 2.37$ (d, $J=3.6 \mathrm{~Hz}, 6 \mathrm{H}), 2.06-1.94(\mathrm{~m}, 2 \mathrm{H}), 1.92-1.59(\mathrm{~m}, 8 \mathrm{H})$, $0.99-0.89(\mathrm{~m}, 18 \mathrm{H}), 0.08(\mathrm{~s}, 12 \mathrm{H}) .{ }^{13} \mathrm{C} \mathrm{NMR}\left(101 \mathrm{MHz}, \mathrm{CD}_{2} \mathrm{Cl}_{2}\right)$ $\delta 167.1(2 \mathrm{C}), 158.8$ and $158.8(2 \mathrm{C}), 130.2$ and $130.0(2 \mathrm{C}), 71.1$ and $71.0\left(2 \mathrm{CH}_{2}\right), 66.8$ and $66.8\left(2 \mathrm{CH}_{2}\right), 65.7$ and $65.5\left(2 \mathrm{CH}_{2}\right), 51.6\left(2 \mathrm{CH}_{3}\right), 34.8$ and 34.7 $\left(2 \mathrm{CH}_{2}\right), 32.1$ and $31.9\left(2 \mathrm{CH}_{2}\right), 31.9(2 \mathrm{CH}), 26.2\left(6 \mathrm{CH}_{3}\right), 18.7(2 \mathrm{C}), 14.8$ and $14.7\left(2 \mathrm{CH}_{3}\right),-5.24$ and $-5.21\left(4 \mathrm{CH}_{3}\right)$; IR (neat) $\tilde{v} / \mathrm{cm}^{-1}: 2932,2857,1740,1618,1469,1435,1384,1254,1189$, 1157, 1084, 833, 774, 732, 667; HR-MS (ESI): $\mathrm{m} / \mathrm{z}=689.4108[\mathrm{M}+\mathrm{H}]^{+}$(calculated for $\mathrm{C}_{34} \mathrm{H}_{65} \mathrm{O}_{10} \mathrm{Si}_{2} \mathrm{~m} / \mathrm{z}=689.4111$ ); Diastereomeric ratio $(d r)$ 1.0:0.8. 


\section{NMR spectra}

${ }^{1} \mathrm{H}$ NMR - 1-(4,5,6,7-tetrachloro-1,3-dioxoisoindolin-2-yl)cyclohexane-1-carboxylic acid (TCPTCC)

DP_CatSynth_DCM2.10.fid 6
1HPROTON

$\begin{array}{ll}1 \mathrm{H} \text { PROTON } \\ 400.13 \mathrm{MHz} & \stackrel{2}{2}\end{array}$

DMSO

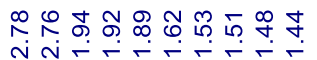

$\underbrace{C}_{\mathrm{Cl}}$

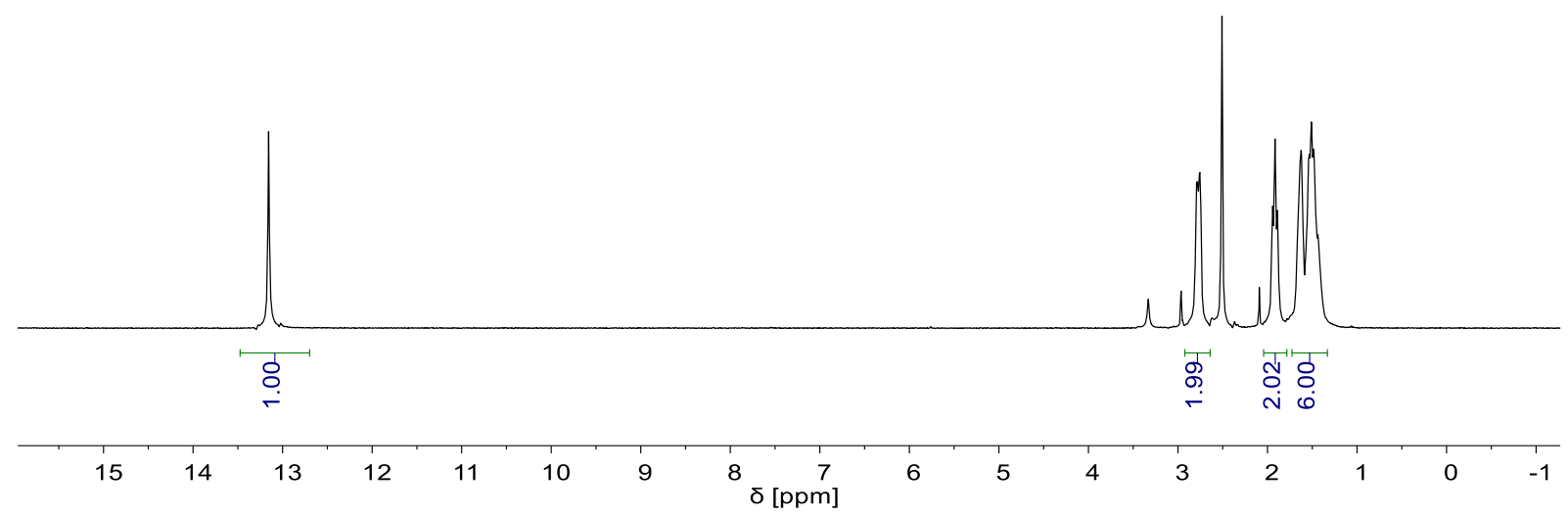

\section{${ }^{13} \mathrm{C}$ NMR}

DP CatSynth DCM2.11. fid 13C CARBON

$100.62 \mathrm{MHz}$

กิก กับ

$298.1 \mathrm{~K}$

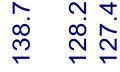

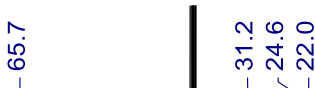

$1 \backslash 1$

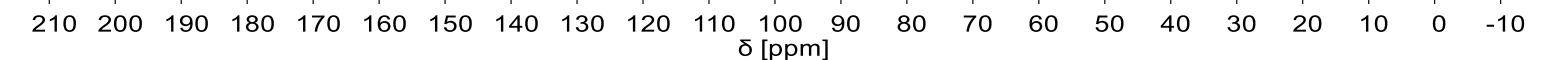




\section{${ }^{1}$ H NMR - $2 f$}

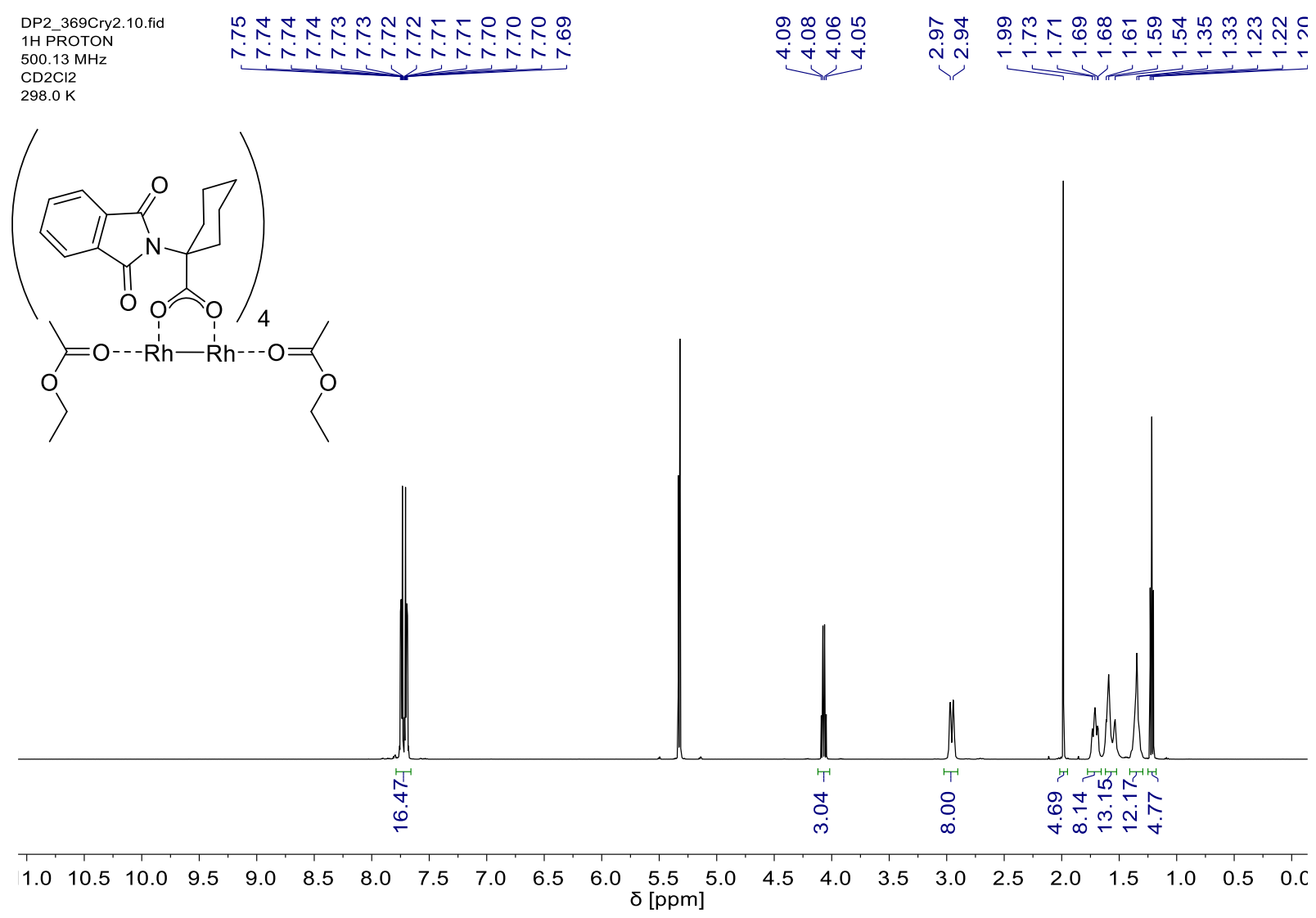

\section{${ }^{13} \mathrm{C}$ NMR - $2 f$}

DP2 369Cry2.11 fid $13 \mathrm{C}$ CARBON

$25.77 \mathrm{MHZ}$

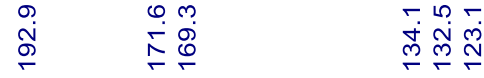

\begin{tabular}{ll}
0 & \multirow{1}{0}{} \\
0 & 8 \\
1 & 1
\end{tabular}

ก เ

$298.0 \mathrm{~K}$

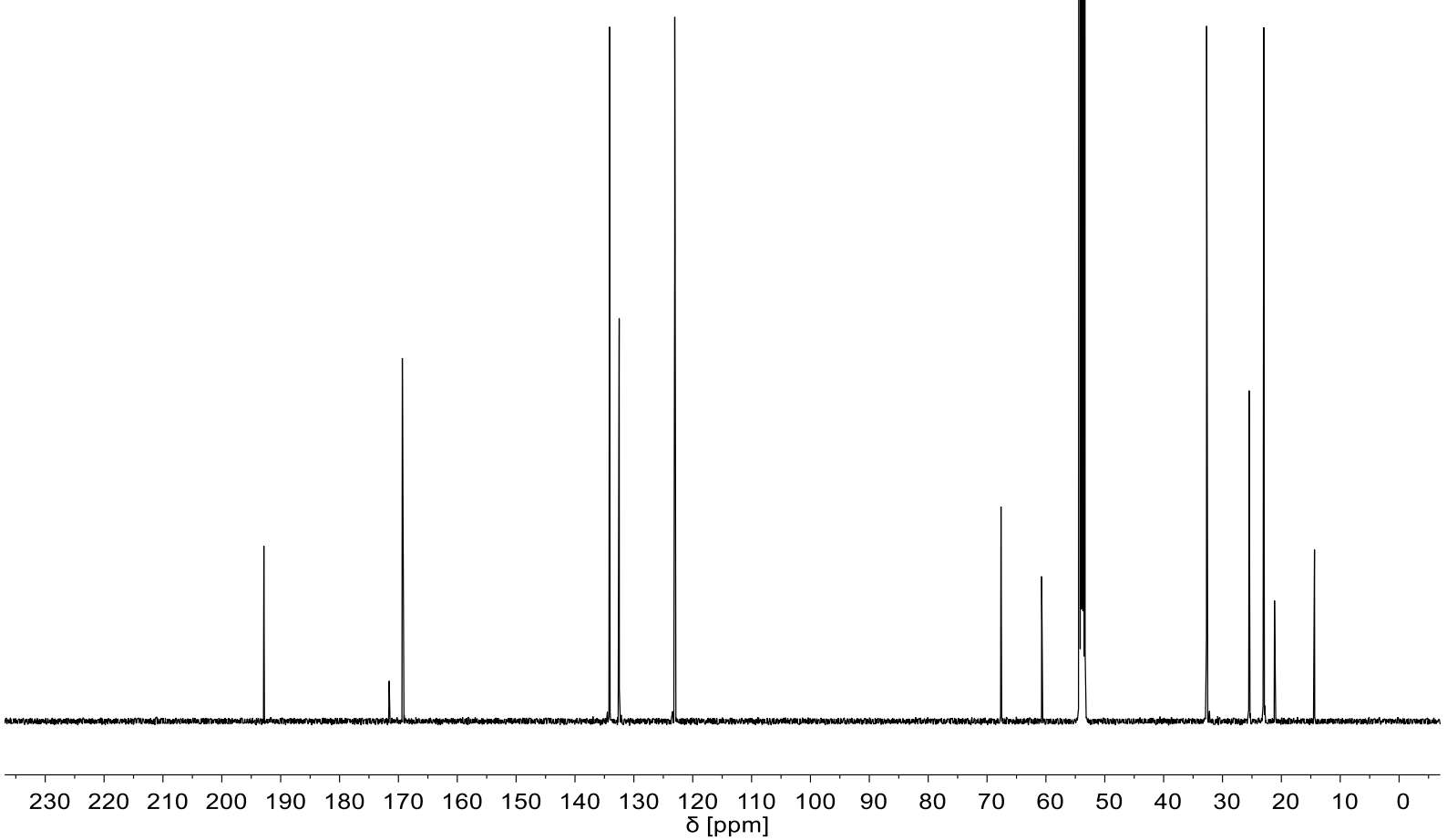




\section{${ }^{1} \mathrm{H} N M R-2 g$}

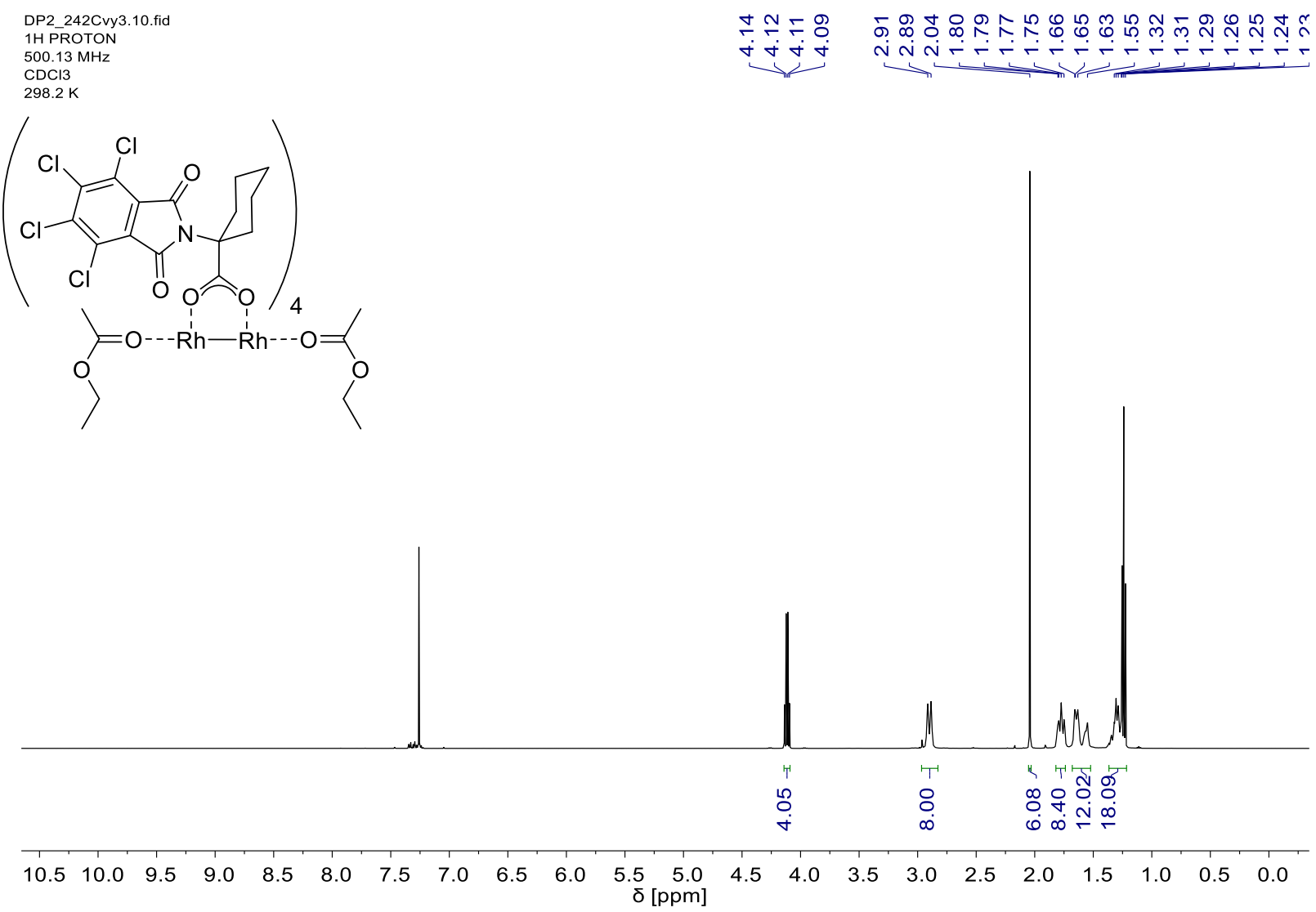

\section{${ }^{13} \mathrm{C}$ NMR- 2g}

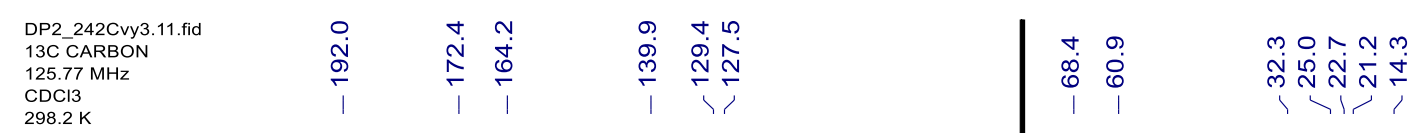

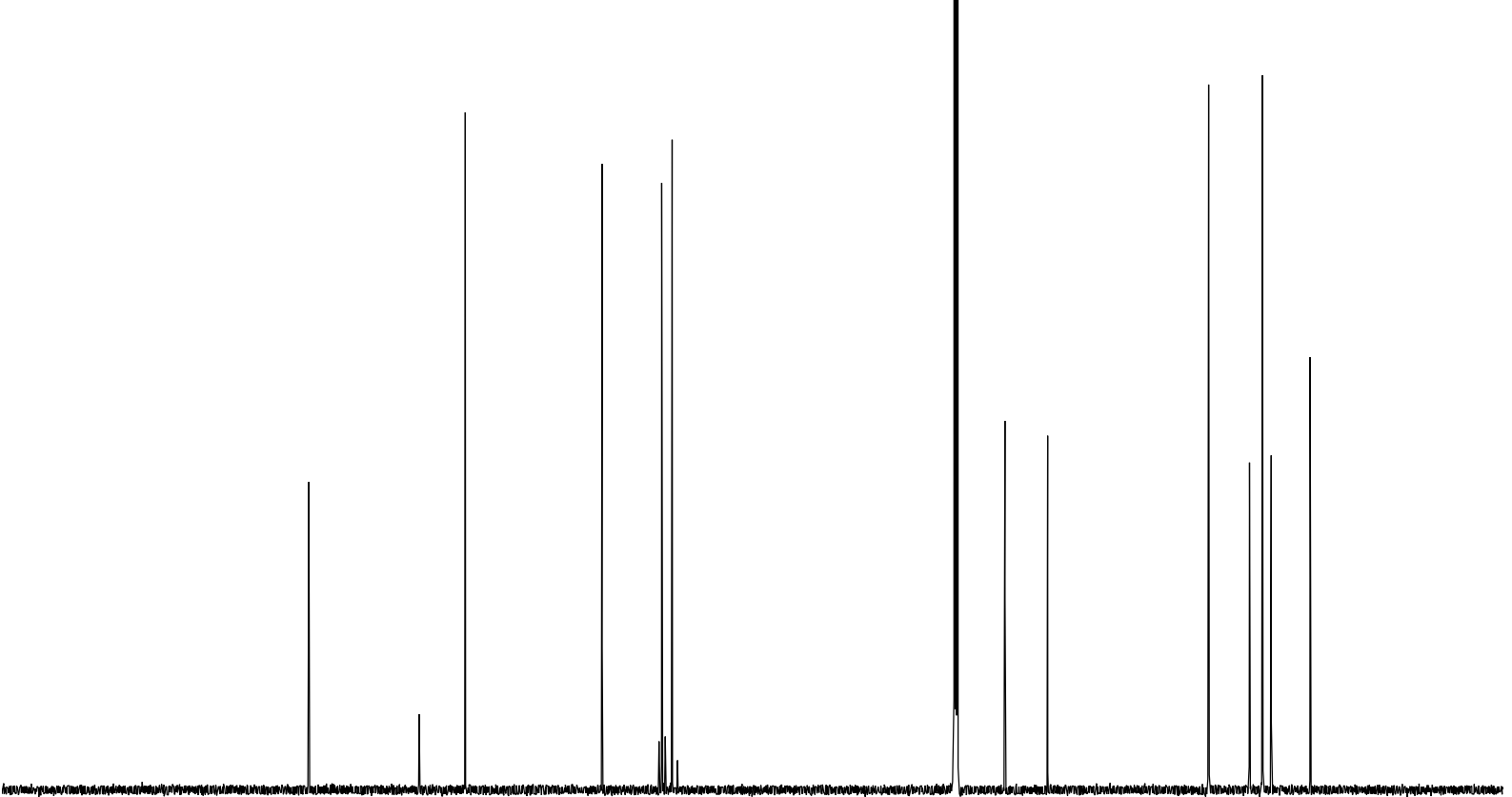

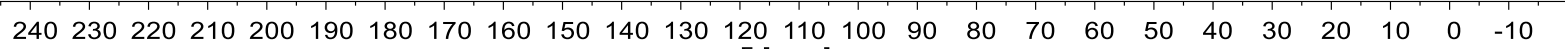
$\delta$ [ppm] 


\section{${ }^{1} \mathrm{H}$ NMR - 6}

ah-843bis.10.fid $1 \mathrm{H}$ PROTON $500.13 \mathrm{MH}$

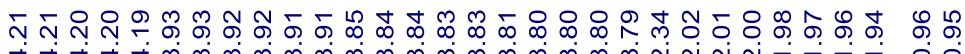

$\mathrm{CDCl} 3$<smiles>COCCO/C(C(=O)OCC(C)C)=C(\C)OCCOCCOC(C(=O)OCC(C)C)=C(C)OCCOCC(C)C</smiles>

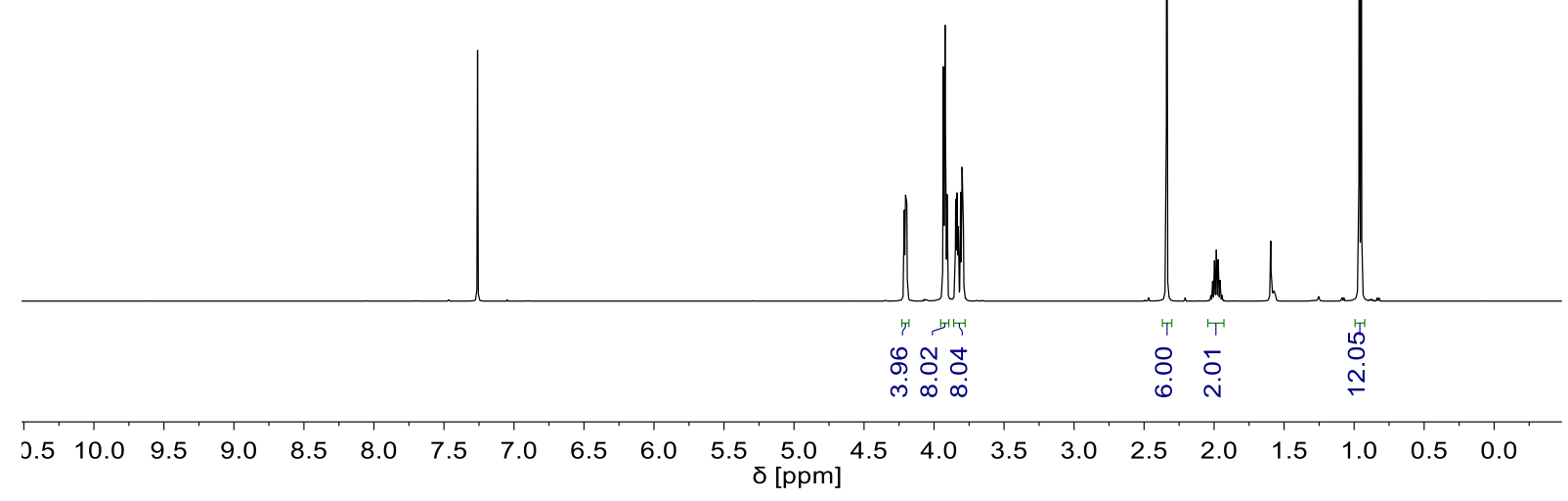

${ }^{13}$ C NMR - 6

ah-843bis.11.fid 13C CARBON

$125.77 \mathrm{MHz}$

$\mathrm{CDCl} 3$

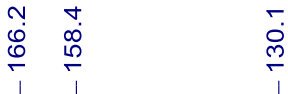

$\stackrel{\check{m}}{\check{r}}$

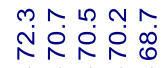

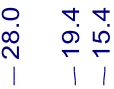

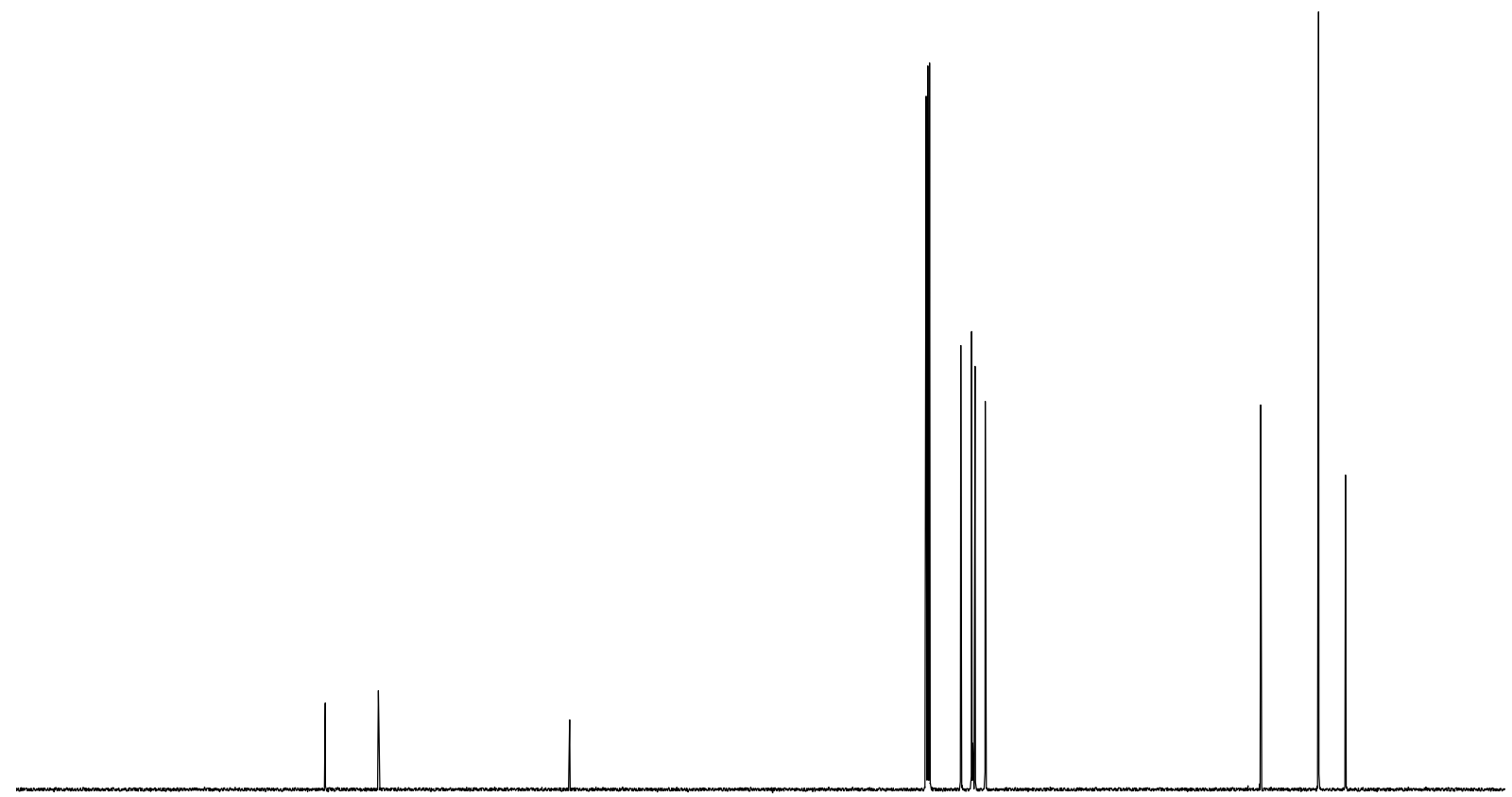

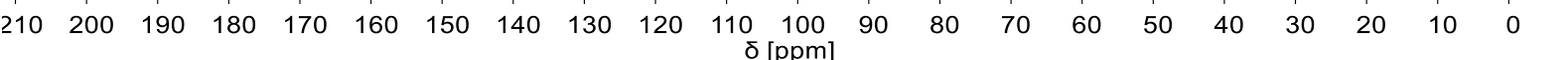




\section{${ }^{1} \mathrm{H}$ NMR - 7}

ah-847bis.10.fid

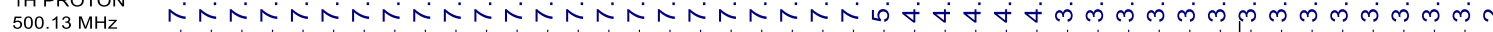
$\mathrm{CDCl} 3$

$298.2 \mathrm{~K}$<smiles>[Z7]COCCOC(C(=O)OCc1ccccc1)/C(C)=C(/C)OCCOCCO/C(C(=O)OCc1ccccc1)=C(\C)OCc1ccccc1</smiles>

7

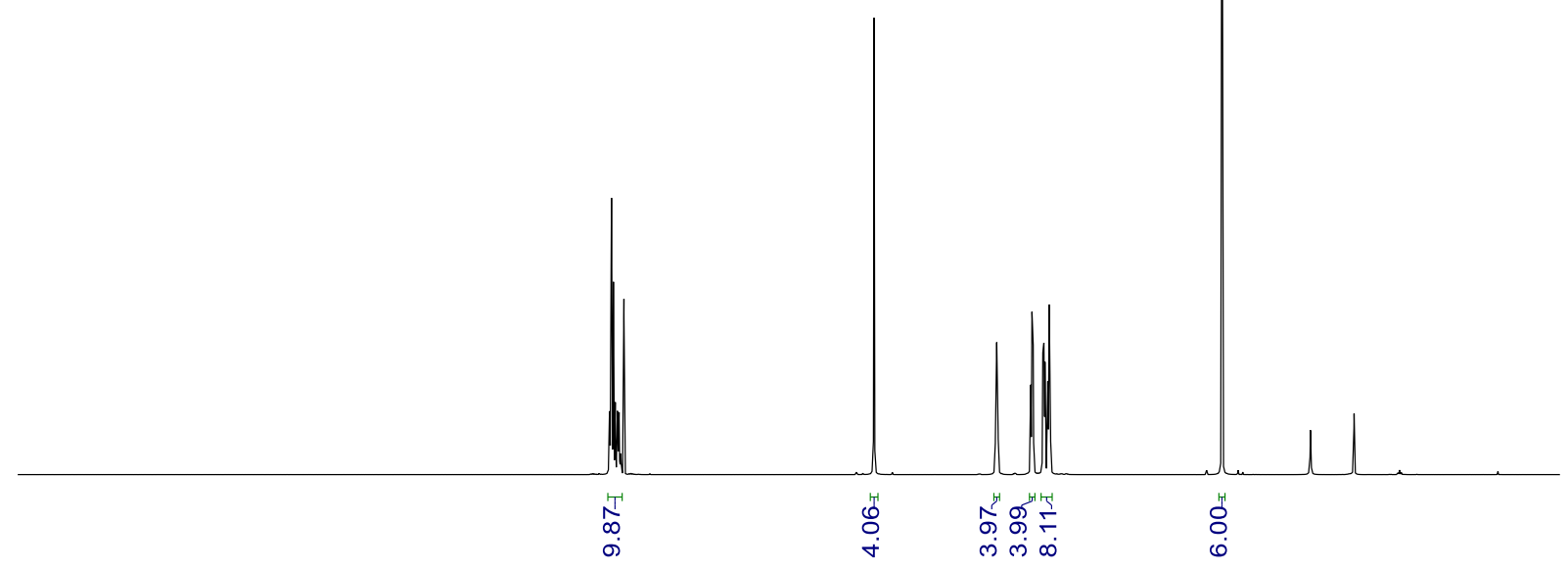

$\begin{array}{llllllllllllllllllllllllllllll}12.0 & 11.5 & 11.0 & 10.5 & 10.0 & 9.5 & 9.0 & 8.5 & 8.0 & 7.5 & 7.0 & 6.5 & 6.0 & 5.5 & 5.0 & 4.5 & 4.0 & 3.5 & 3.0 & 2.5 & 2.0 & 1.5 & 1.0 & 0.5 & 0.0\end{array}$

${ }^{13} \mathrm{C}$ NMR - 7

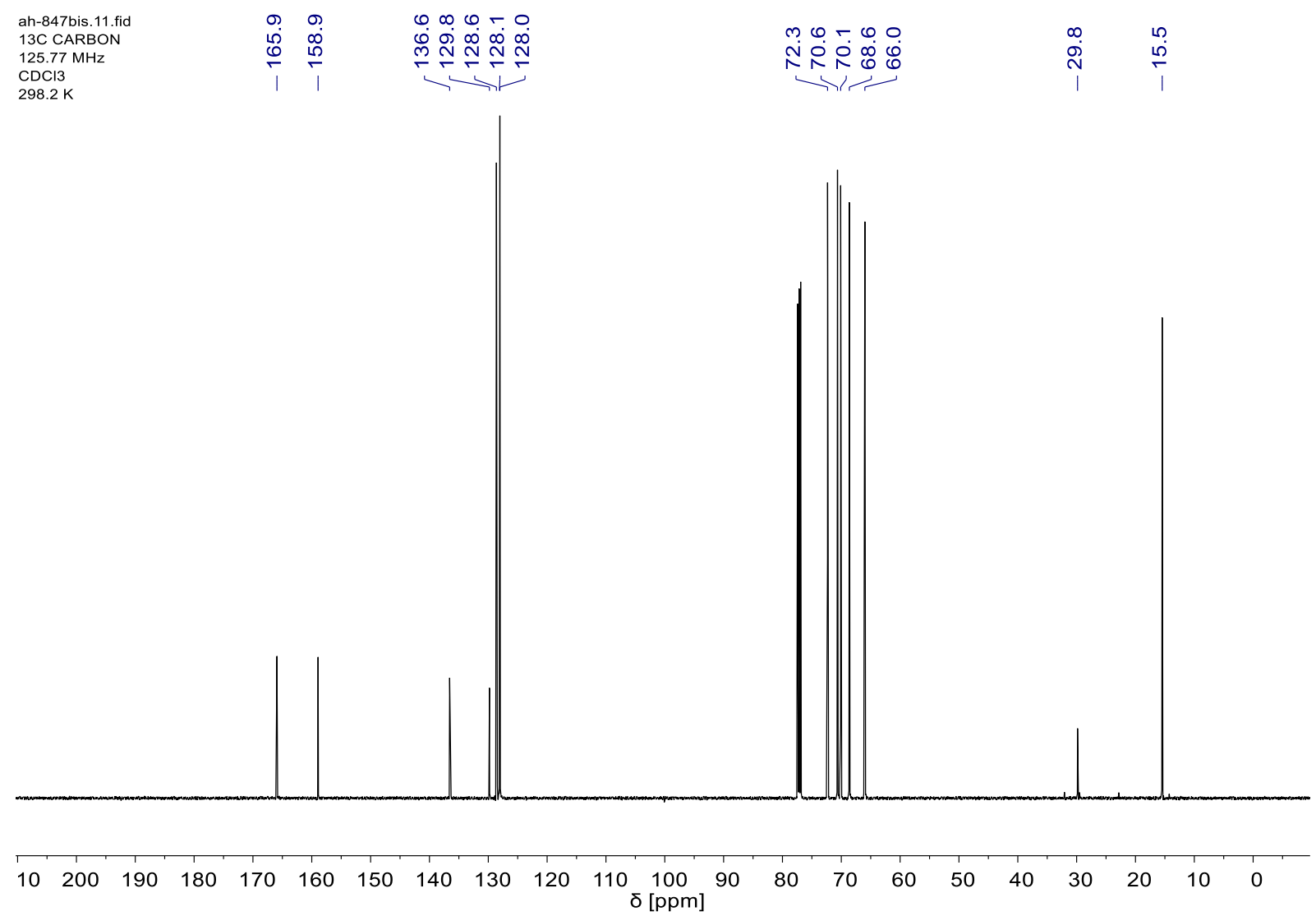




\section{${ }^{1} \mathrm{H}$ NMR - 9}

ah-857bis.10.fid

1H PROTON
$500.13 \mathrm{MHz}$

$\mathrm{CDCl} 3$<smiles>C/C1=C(\C(=O)OCC(Cl)(Cl)Cl)OCCOCCO/C(C(=O)OCC(Cl)(Cl)Cl)=C(\C)OCCOCCO1</smiles>

চ

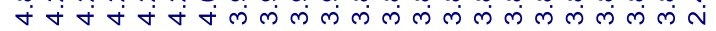

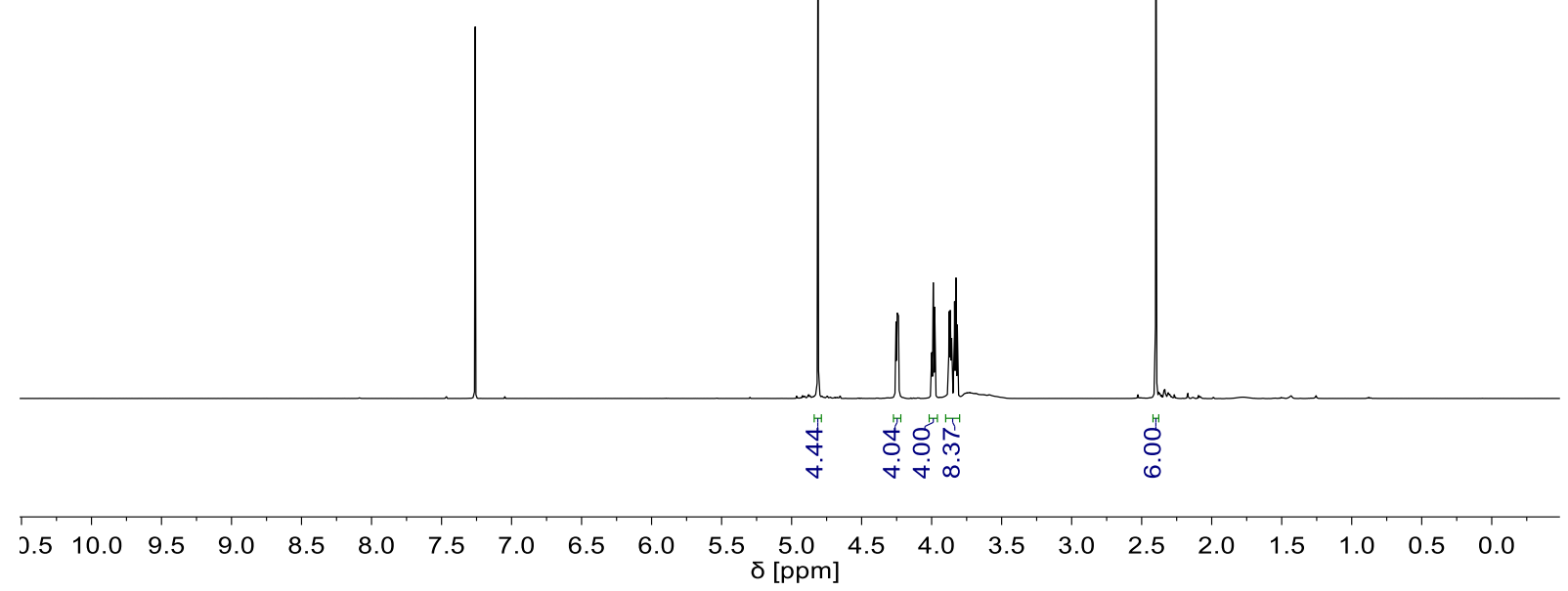

${ }^{13} \mathrm{C}$ NMR - 9

ah-857bis.11.fid $13 \mathrm{C}$ CARBON

$125.77 \mathrm{MHz}$

$\mathrm{CDCl} 3$
$298.2 \mathrm{~K}$

$\stackrel{+}{\stackrel{1}{*} \frac{1}{6}}$

$\stackrel{\infty}{\stackrel{\infty}{\circ}} \underset{\sim}{+}$

مُ

$\stackrel{+}{i}$

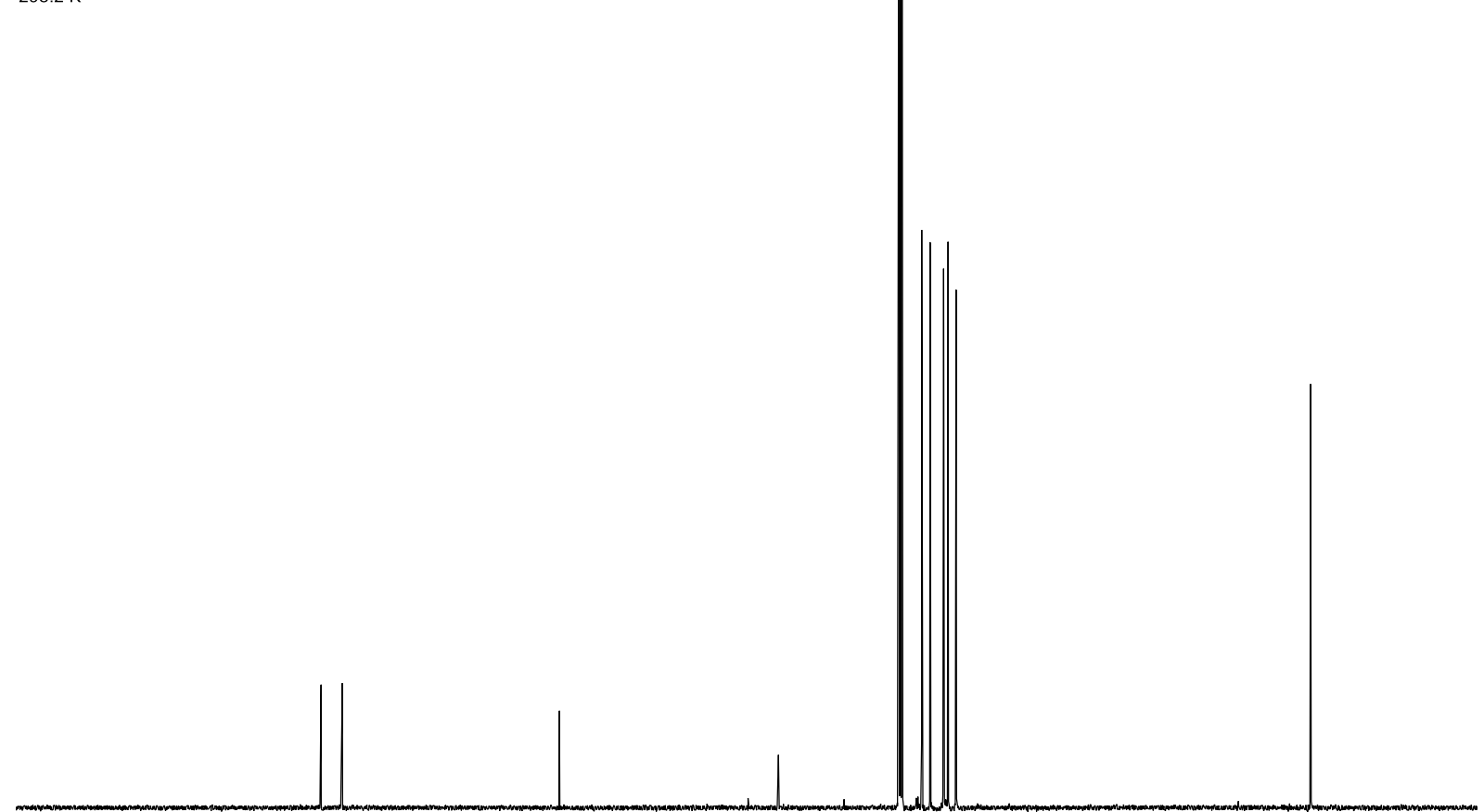

$\begin{array}{llllllllllllllllllllllllllll}10 & 200 & 190 & 180 & 170 & 160 & 150 & 140 & 130 & 120 & 110 & 100 & 90 & 80 & 70 & 60 & 50 & 40 & 30 & 20 & 10 & 0 & 0\end{array}$ 


\section{${ }^{1} \mathrm{H}$ NMR - 11}

ah-853.10.fid $1 \mathrm{H}$ PROTON $500.13 \mathrm{MHz}$

$298.2 \mathrm{~K}$

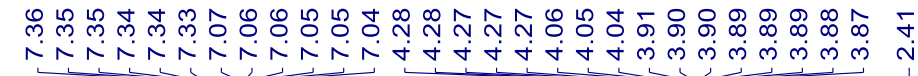

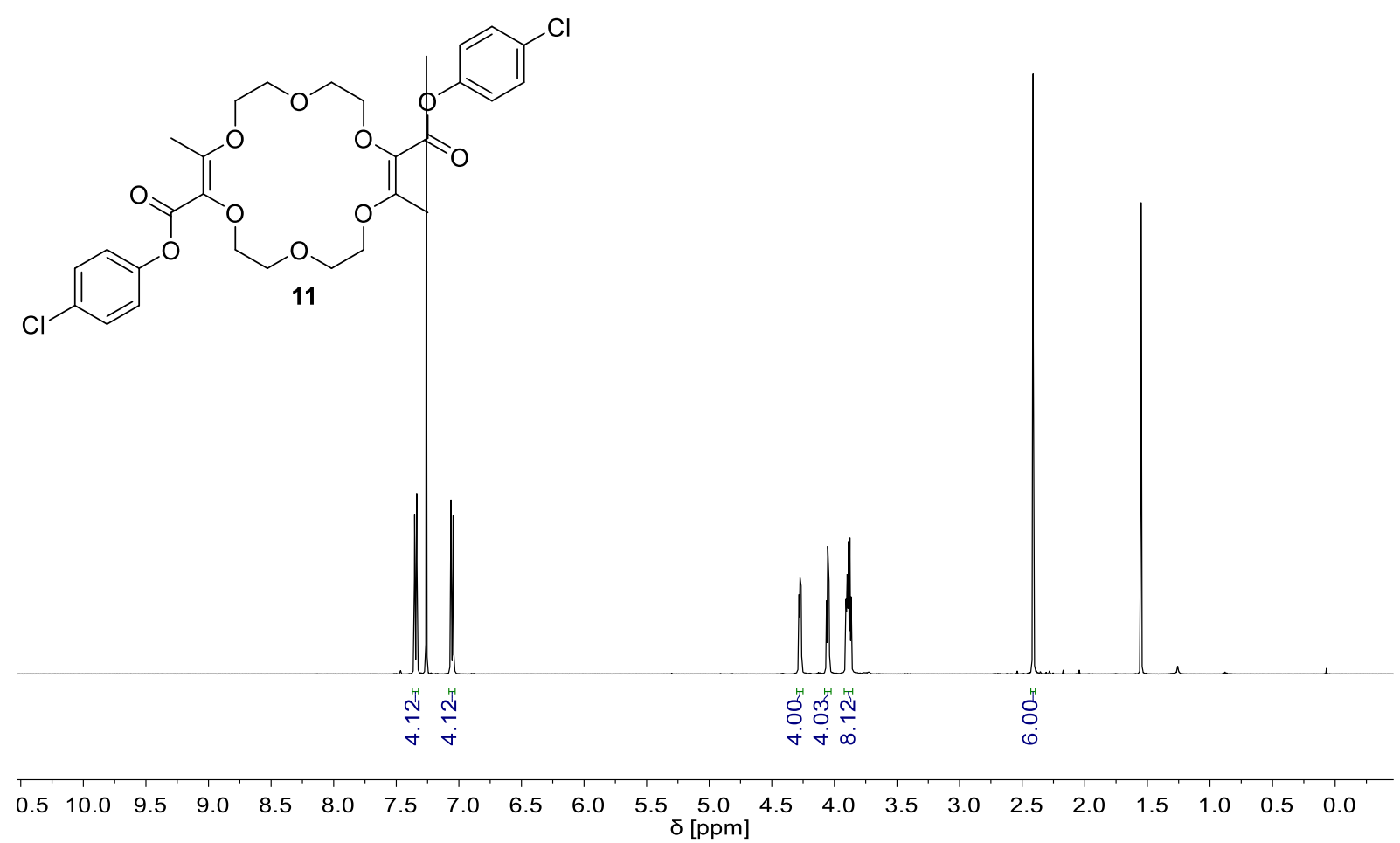

${ }^{13} \mathrm{C}$ NMR - 11

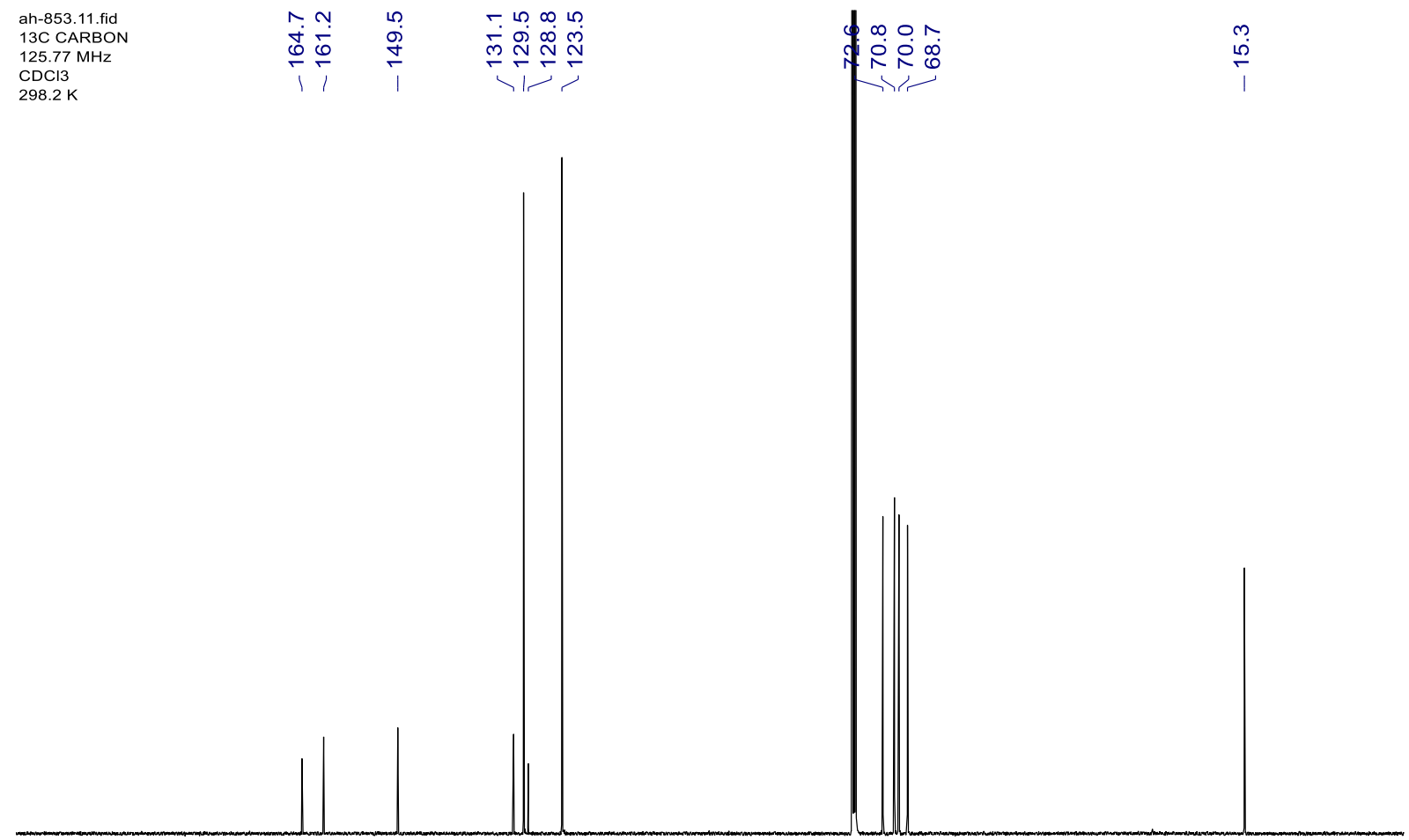

$\begin{array}{llllllllllllllllllllllllllll}200 & 190 & 180 & 170 & 160 & 150 & 140 & 130 & 120 & 110 & 100 & 90 & 80 & 70 & 60 & 50 & 40 & 30 & 20 & 10 & 0 & -\end{array}$. 


\section{${ }^{1} \mathrm{H}$ NMR - 12}

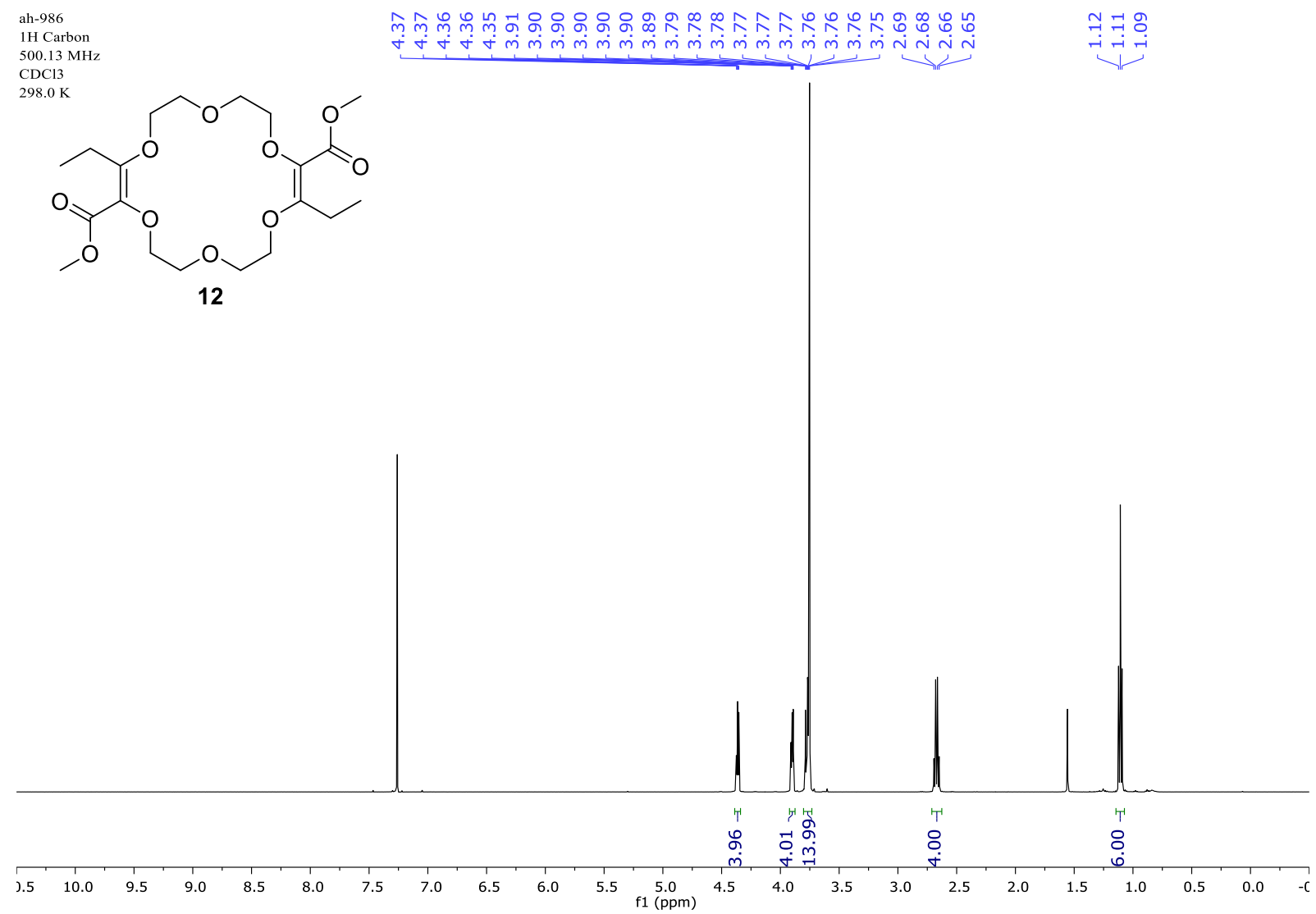

${ }^{13} \mathrm{C}$ NMR - 12

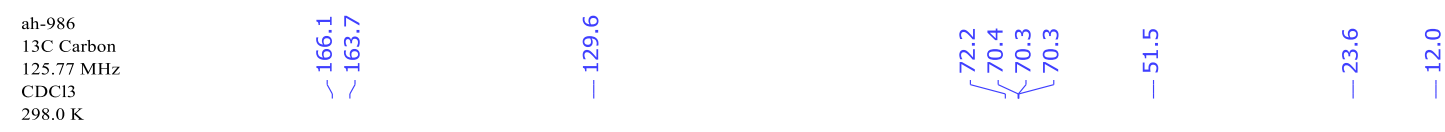

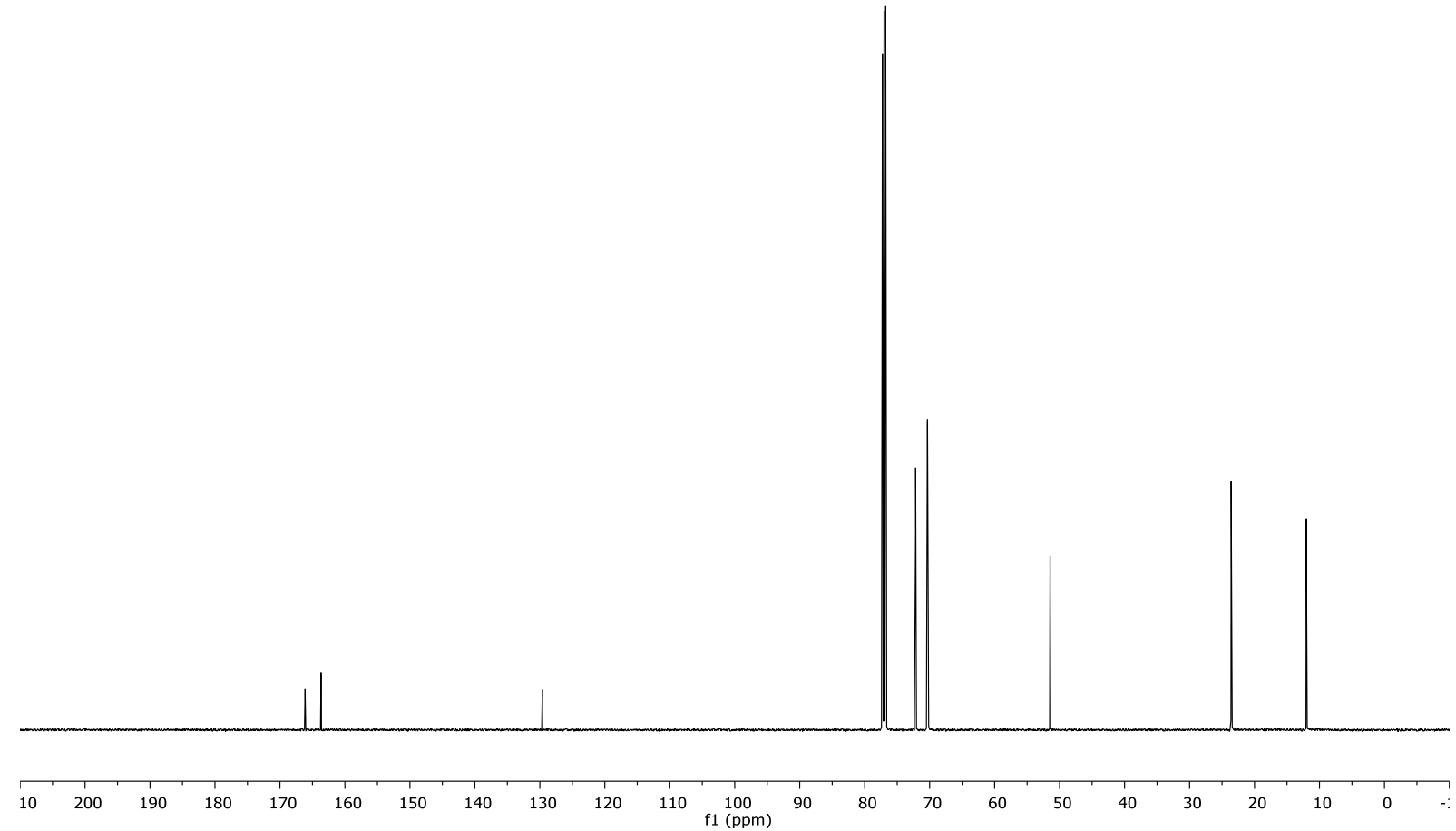




\section{${ }^{1} \mathrm{H}$ NMR - 13}

ah-988

$1 \mathrm{H}$ Proton
$500.13 \mathrm{MHz}$

$\mathrm{CDCl} 3$<smiles>CCCC1=C(C(=O)OC)OCCOCCOC(CCC)C(C(=O)OC)OCCOCCO1</smiles>

13

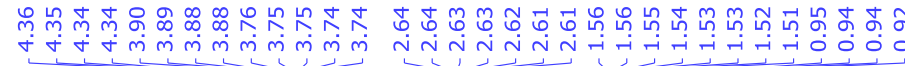

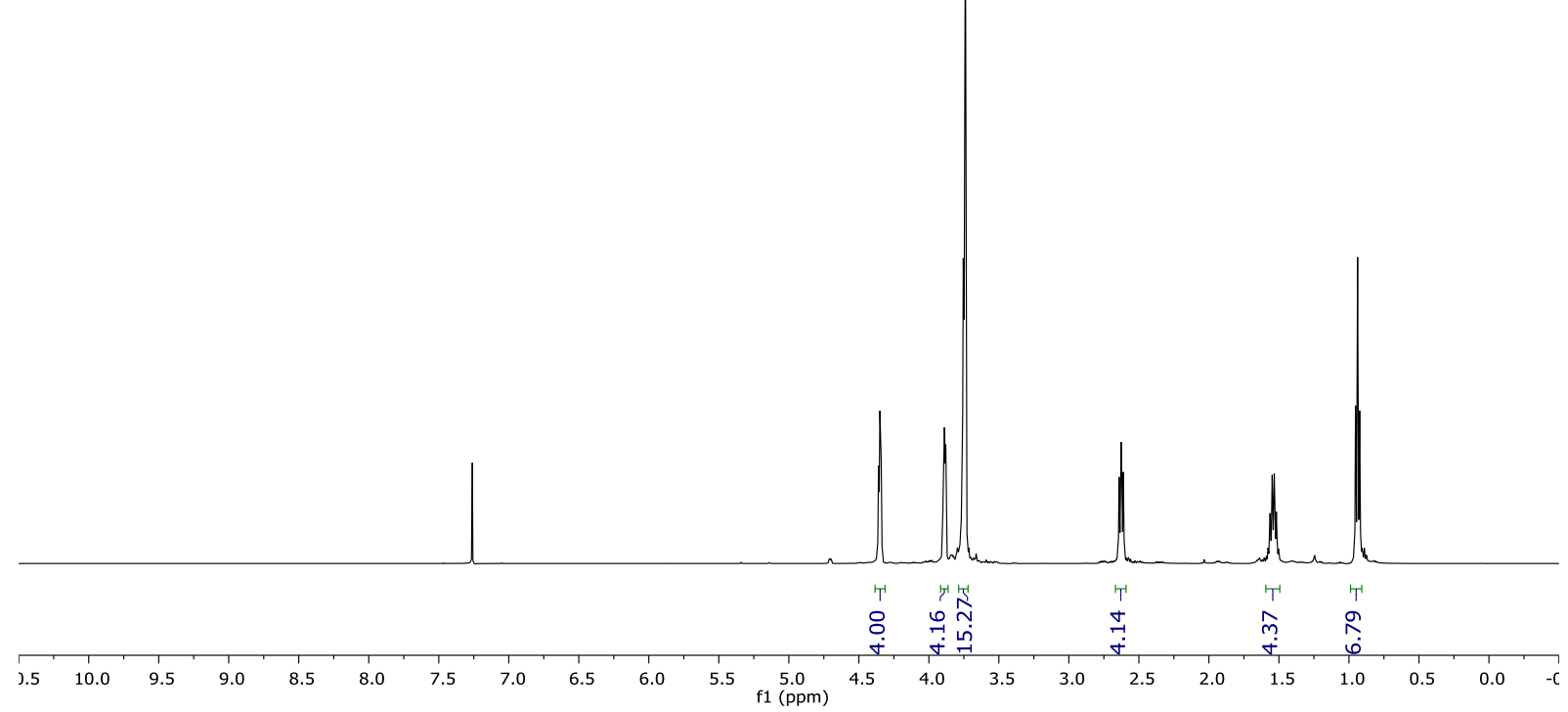

${ }^{13} \mathrm{C}$ NMR - 13

ah- 988

13C Carbon
$125.77 \mathrm{MHz}$

$\mathrm{CDCl} 3$

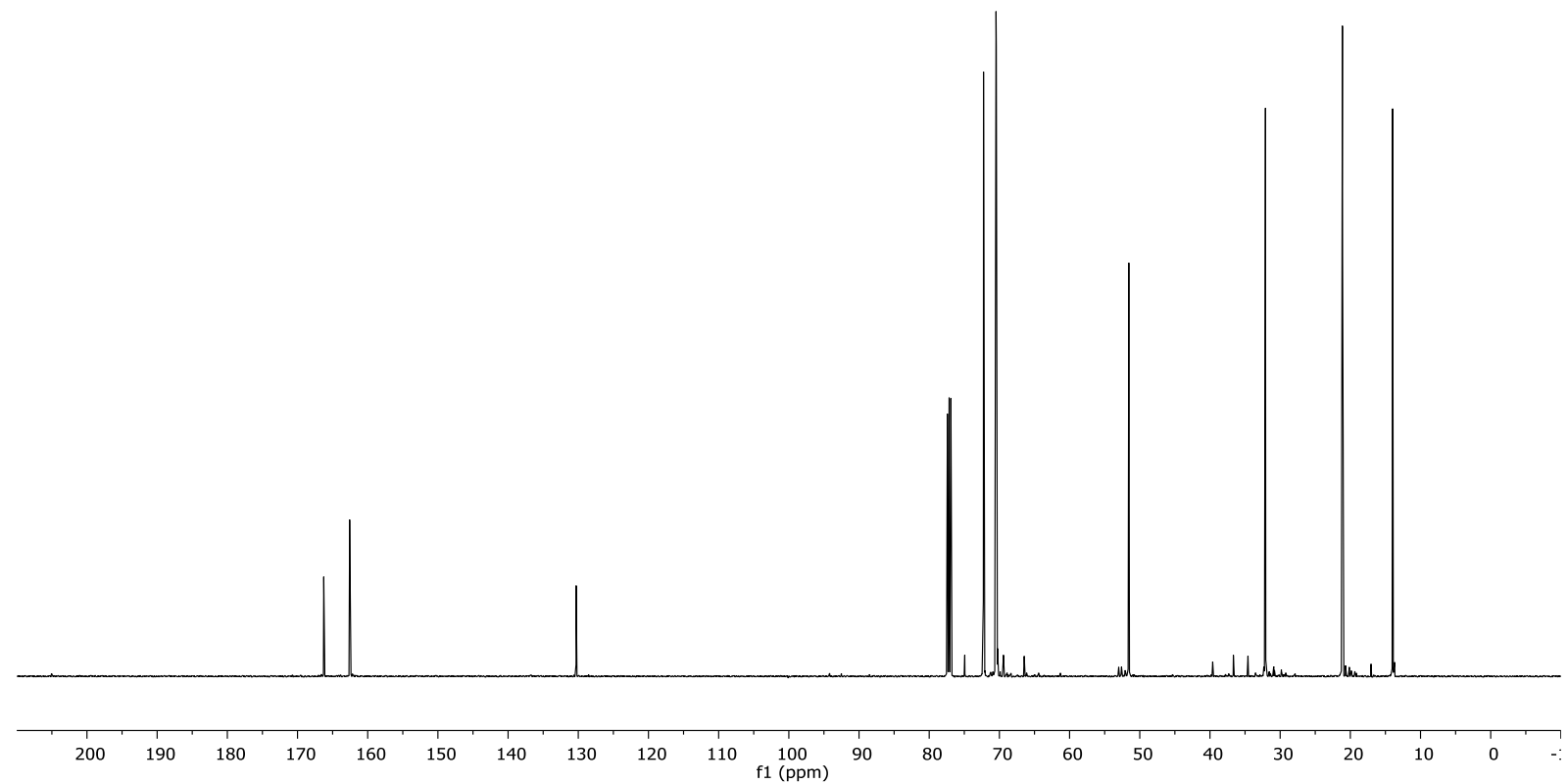


${ }^{1}$ H NMR - THP precursor of macrocycle 16

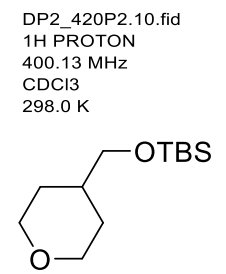

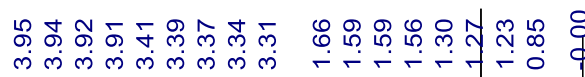

18

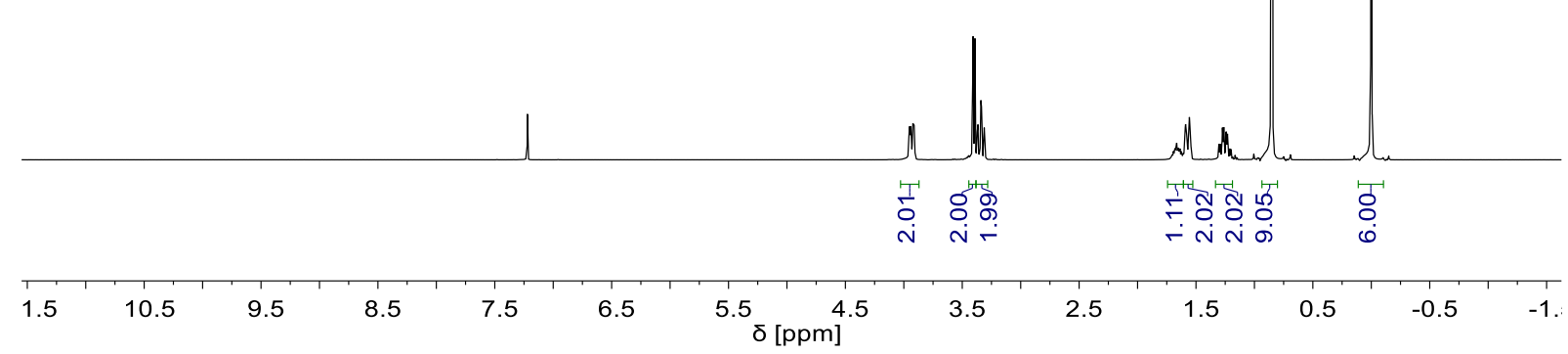

${ }^{13} \mathrm{C}$ NMR - THP precursor of macrocycle 16

DP2_420P2.12.fid

$13 C$ CARBON

$\mathrm{CDCl} 3$

0
0
0
0
0

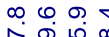

ले

$298.0 \mathrm{~K}$

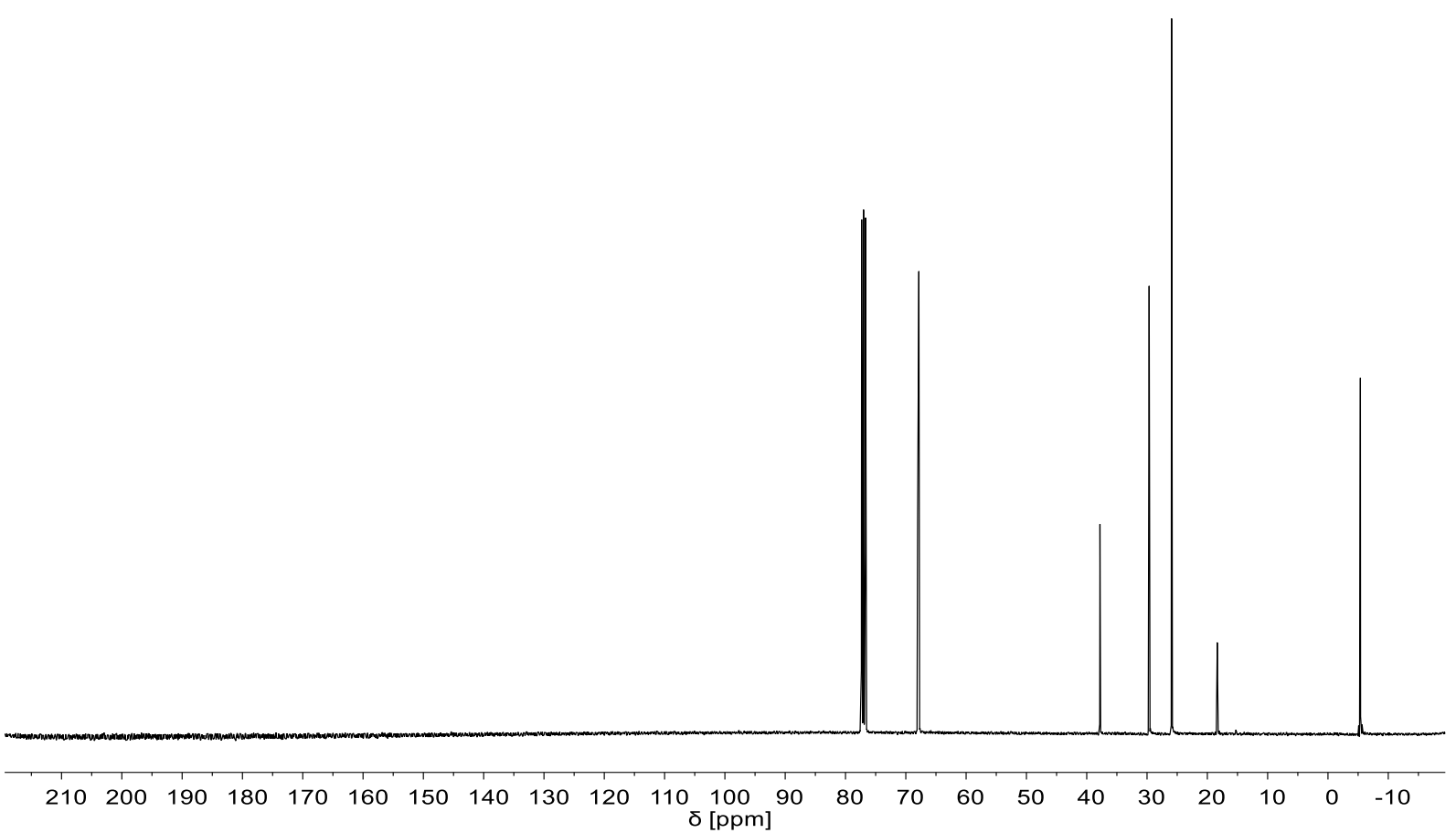




\section{${ }^{1}$ H NMR - 16}

DP2_THPCH2OTBS_0-01_PA2.10.fid $1 \mathrm{H}$ PROTON

$400.13 \mathrm{MHz}$

$\mathrm{CD} 2 \mathrm{Cl} 2$

$298.0 \mathrm{~K}$

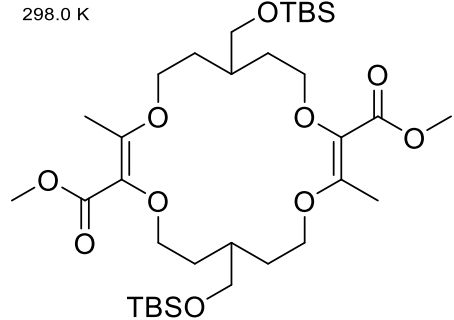

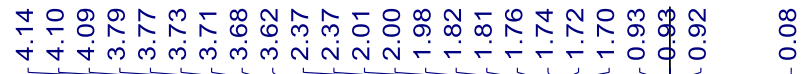

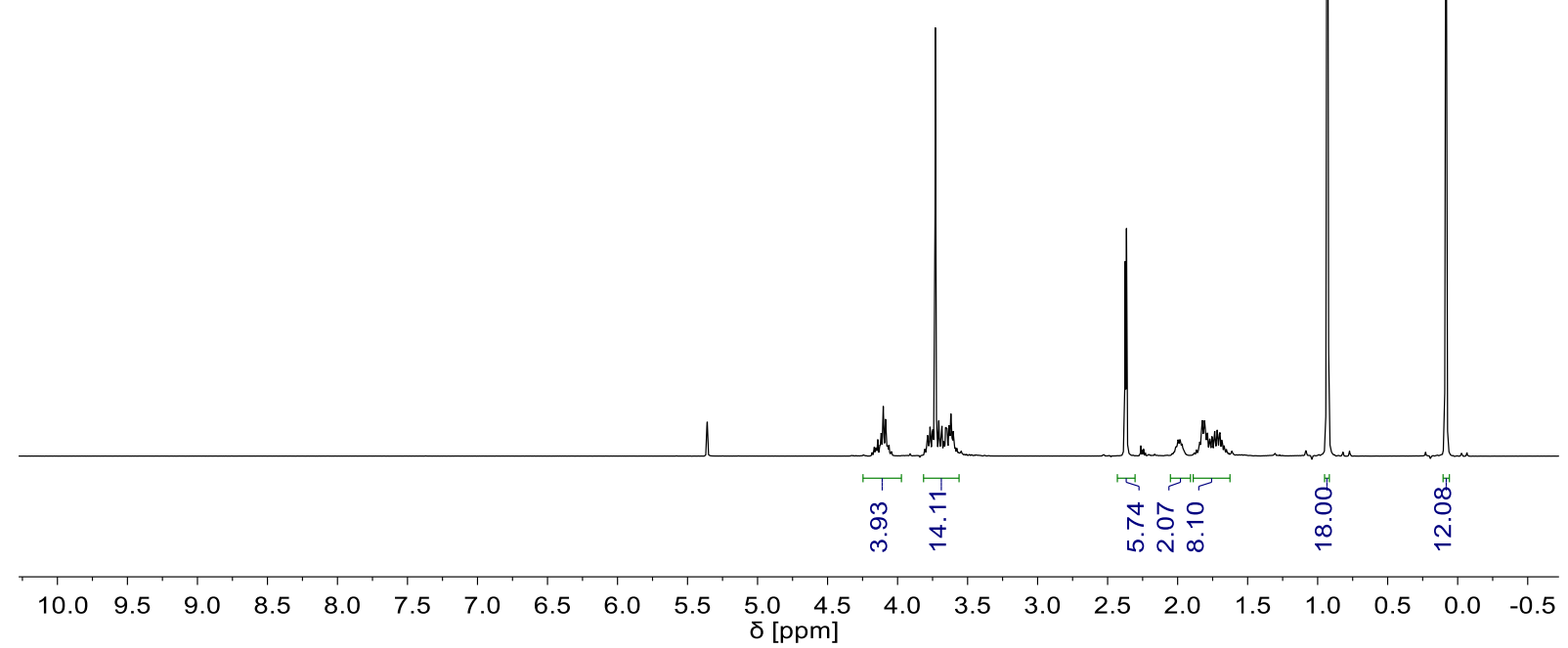

${ }^{13} \mathrm{C}$ NMR - 16

DP2_THPCH2OTBS_0-01_PA2.11.fidO $\boldsymbol{\sim}$ $13 \mathrm{C}$ CARBON $100.62 \mathrm{MH}$ $\mathrm{CD} 2 \mathrm{Cl} 2$

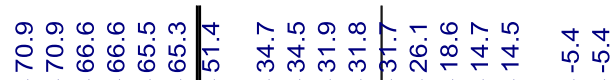
N

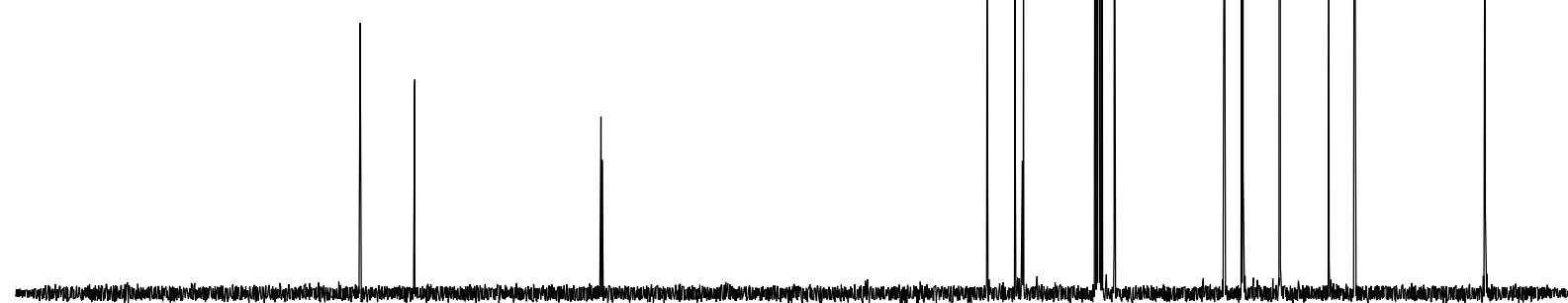

$\begin{array}{lllllllllllllllllllllllllllllllll}210 & 200 & 190 & 180 & 170 & 160 & 150 & 140 & 130 & 120 & 110 & 100 & 90 & 80 & 70 & 60 & 50 & 40 & 30 & 20 & 10 & 0 & -10\end{array}$ 


\section{References}

(1) Tsutsui, H.; Abe, T.; Nakamura, S.; Anada, M.; Hashimoto, S., Chem. Pharm. Bull. 2005, 53, 1366-1368.

(2) Zeghida, W.; Besnard, C.; Lacour, J., Angew. Chem. Int. Ed. 2010, 49, 7253-7256.

(3) Alderighi, L.; Gans, P.; lenco, A.; Peters, D.; Sabatini, A.; Vacca, A., Coord. Chem. Rev. 1999, 184, 311-318.

(4) Chuprakov, S.; Worrell, B. T.; Selander, N.; Sit, R. K.; Fokin, V. V., J. Am. Chem. Soc. 2013, 136, 195-202.

(5) A standard solution was prepared in a $2 \mathrm{~mL}$ volumetric flask containing the catalyst (mass $>1$ $\mathrm{mg}$ ) and $\mathrm{CHCl}_{3}$. The volume corresponding to the desired amount of catalyst was introduced in the reaction vessel and the remaining volume of $\mathrm{CHCl}_{3}$ was added.

(6) Martínez, L. E.; Nugent, W. A.; Jacobsen, E. N., J. Org. Chem. 1996, 61, 7963-7966.

(7) Kazem Shiroodi, R.; Dudnik, A. S.; Gevorgyan, V., J. Am. Chem. Soc. 2012, 134, 6928-6931.

(8) Vishe, M.; Hrdina, R.; Guénée, L.; Besnard, C.; Lacour, J., Adv. Synth. Catal. 2013, 355, 31613169. 